\title{
Constitutional Rhetoric: The Genre Performances of the Written Constitution in Transnational, Transcultural Contexts
}

Bhushan Aryal

Follow this and additional works at: https://researchrepository.wvu.edu/etd

\section{Recommended Citation}

Aryal, Bhushan, "Constitutional Rhetoric: The Genre Performances of the Written Constitution in Transnational, Transcultural Contexts" (2018). Graduate Theses, Dissertations, and Problem Reports. 7156.

https://researchrepository.wvu.edu/etd/7156

This Dissertation is protected by copyright and/or related rights. It has been brought to you by the The Research Repository @ WVU with permission from the rights-holder(s). You are free to use this Dissertation in any way that is permitted by the copyright and related rights legislation that applies to your use. For other uses you must obtain permission from the rights-holder(s) directly, unless additional rights are indicated by a Creative Commons license in the record and/ or on the work itself. This Dissertation has been accepted for inclusion in WVU Graduate Theses, Dissertations, and Problem Reports collection by an authorized administrator of The Research Repository @ WVU.

For more information, please contact researchrepository@mail.wvu.edu. 


\title{
Constitutional Rhetoric: The Genre Performances of the Written Constitution in Transnational, Transcultural Contexts
}

\author{
Bhushan Aryal
}

Dissertation submitted to the Eberly College of Arts and Sciences at West Virginia University In partial fulfilment of the requirements for the degree of

\author{
Doctor of Philosophy in English \\ Laura Brady, Ph.D., Co-chair \\ Timothy Sweet, Ph.D., Co-chair \\ Catherine Gouge, Ph.D. \\ Thomas Sura, Ph.D. \\ Scott Wible, Ph.D. \\ Department of English
}

Morgantown, West Virginia

2018

Keywords: Constitutional Rhetoric, Republicanism and Constitution, Nepali Constitution, Cherokee Constitution, Constitutional authorship, constitution as a genre, subjective republicanism.

Copyright 2018 (Bhushan Aryal) 


\section{ABSTRACT \\ Constitutional Rhetoric: The Genre Performance of the Written Constitution in Transnational, Transcultural Contexts \\ Bhushan Aryal}

A new kind of project within the broad field of writing studies, this dissertation studies the written constitution as a genre from the lens of rhetorical genre studies, for which it uses the constitutions of the United States, Cherokee Nation, and Nepal as sample cases because of their historical and cultural differences. Analyzing why and how the genre originated in the United States in the eighteenth-century, and how it was used in the two other contexts subsequently, the study demonstrates the double dynamics in the use of the genre: while the genre modifies genrereceiving contexts by its ideological/functional structures, the adopters also appropriate it to achieve their needs. That the degree — not the kind — of that double dynamics differs from one rhetorical context to another, and that knowing that degree of a particular genre use requires a careful observation of the associated players, historical context, and texts is the central demonstration of this dissertation. For instance, the Cherokee Nation in 1827 adopted the U.S.modelled constitution to resist their removal, but, in the process, they redefined the tribe's nature of government and sovereignty. In the context of the United States in 1780s, the genre served as the defining conduit for the republicanism's transition from I call "subjective republicanism" to a pragmatic form of governance. The analysis of the actors' motivations involved in the seven constitutions of Nepal demonstrates that the hegemonic global ascendency of the written constitution in the twentieth-century required even traditional rulers to adopt the genre so that they can legitimize their rule within the country and receive recognition from international community, although they did not have the interest to observe the idealistic view of constitutionalism embedded in the genre's 'original' disposition. Nepal's constitutional history also suggests that the question of what counts as the legitimate author of a constitution could be a conflicting factor between the forces of tradition and modernity in a culture with a different form of legitimization for its legal codes. Cumulatively, this comparative study of the transnational, transcultural, and tranlingual application of the written constitution in a broad historical context spanning two centuries shows two major tendencies: One the one hand, the genre mobilizes an idealistic democratic aspiration for the rule of law designed by collective human sovereignty. On the other hand, the genre gets utilized for arbitrary rules because of its power of legitimization. But the genre falls under higher strain when the deeper contention arises because the idealistic applications themselves cannot decide on the definitions of the master tropes of modernity such as equity, democracy, and constitutional authorship.

This study's significance lies at two levels. First, while scholars, including rhetoric and composition specialists, have researched and commented on the U.S. Constitution and other constitutions, this dissertation is the first substantial study of the written constitution from rhetorical genre perspective. Thus, the project offers rhetoric and writing scholars with the new cases not only demonstrating the power of genre studies to define larger national narratives, but also illustrating complexities of high-stake, large-scale, public collaborative writing projects. At the second level, the project also is in dialogue with the existing scholarship in the contexts of the cases and makes specific contributions there. 


\section{Acknowledgements}

Thank you, Dr. Laura Brady and Dr. Timothy Sweet, for your advisement, encouragement, and support throughout the process of writing this dissertation. You have left an indelible mark in my thinking, and it is difficult to say where exactly your ideas end and my ideas begin in this dissertation. You don't know how good, wonderful, and inspirational you are. I'm immensely grateful to both of you. Thanks.

Thanks also to Dr. Thomas Sura, Dr. Catherine Gouge, and Dr. Scott Wible for your time, advice and comments on various stages of the research and writing process of this project.

I must thank Dr. Brian Ballentine, Dr. Adam Komisaruk, Dr. Dennis Allen, Dr. John Jones, Dr. Nathalie Singh-Corcoran, Dr. John Lamb, Dr. Lara Farina, Dr. Lisa Weihman, Dr. Michael Germana, and Dr. Gwen Bergner at the Department of English at WVU.

I'm also thankful to Dr. Shreedhar Lohani, Dr. Ananda Sharma, Dr. Arun Gupto, and Dr. Amma Raj Joshi and all my teachers and colleagues at IACER (Institute of Advanced Communication, Education, and Research) in Kathmandu. These people and the institute molded this country boy from western Nepal into somebody who could navigate the rigors of doctoral study in English in the United States.

As I write this acknowledgement, I'm thinking of my mother and father. The home that they built is deep, dear, and beautiful. As I fleet in time and space, I carry that home wherever I go. Thank you, Ba and Aama.

Of course, almost all the credit for this dissertation goes to Aagya. She did more than she needed to do so that I can work on this long project - not happily always, but with love, faith and common purpose. Love you. 
Table of Contents

Chapter 1: The Rhetoric of the Written Constitution: Genre, Authorship and Sovereignty 1

1.1 Rhetorical Genres, Symbolic World, and Social Performances 8

1.2 Constitutional Genre, Authorship and Sovereignty 12

Chapter 2: The Genre Functions of the Written Constitution, Republicanism, and the Formation of the United States of America 34

$\begin{array}{ll}2.1 \text { Introduction } & 34\end{array}$

2.2 Subjective Republicanism, the Written Constitution, and

$\begin{array}{ll}\text { the Externalization of Virtue } & 37\end{array}$

2.3 Republicanism, Constitutionalism, and the Written Constitution 51

2.4 The Constitution and Unresolved Ambiguities 55

2.5 A Move from Written/ Spoken Word to Genre 59

$\begin{array}{ll}2.6 \text { Conclusion } & 64\end{array}$

Chapter 3: The Cherokee Constitutional Rhetoric: From Eighteen-century Politics of Identification to Twenty-first Century Vision of Transterritorial Sovereignty 66

$\begin{array}{ll}3.1 \text { Introduction } & 66\end{array}$

3.2 The Rhetoric of Survival: Nineteenth-century Cherokee Adoption of the Modernity, the Politics of Identification and the Written Constitution 69

3.3 The First Phase: The Cherokee Transformation and the Politics of Identification 75

3.4 The Second Phase: Cherokee Public Campaign, the Claim of Improvement, and the Politics of Identification $\quad 82$

3.5 The Cherokee Politics of Identification on the Legal Front 99

3.6 Cass-Jackson Rejection of the Cherokee Consubstantiality 107

3.7 Late Twentieth-century Cherokee Constitutional Rhetoric:

$\begin{array}{ll}\text { From Subjection to Sovereignty } & 111\end{array}$

$\begin{array}{ll}\text { 3.8Conclusion } & 125\end{array}$

Chapter 4: Nepali Constitutional Rhetoric: Genre, Authorship and Sovereignty 127

$\begin{array}{ll}4.1 \text { Introduction } & 127\end{array}$

4.2 The 1948 Nepali Constitution and the Genre's Nation-recognizing and

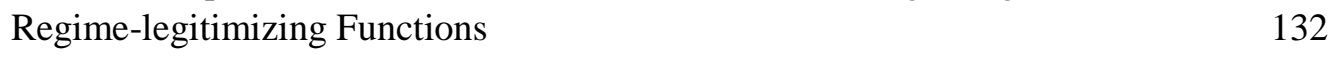

4.3 The 1951 Constitution and the Question of the Genre's Collective Authorship 139

4.4 The 1959 Constitution and the King's Claim of Constitutional Authorship $\quad 146$ 
4.5 The 1962 Constitution and the King as Constitutional Law

4.6 The 1990 Constitution and the Compromised Collective Constitutional Authorship 164

4.7 The 2015 Nepal Constitution and the Genre's Ideological Fissure 177

Chapter 5: The Genre of the Written Constitution: Where Does It Stand Now? 181

Chapter 6: Epilogue: A Short Meditation on the Pedagogical Implications of this Study 187

$\begin{array}{ll}\text { Works Cited } & 193\end{array}$ 


\section{Constitutional Rhetoric: The Genre Performances of the Written Constitution in Transnational, Transnational Contexts (The Cases of the United States, Cherokee Nation, and Nepal)}

\section{Chapter 1: The Rhetoric of the Written Constitution: Genre, Authorship and Sovereignty}

The written constitution is perhaps the most powerful genre in the modern, secular world. It rests at the zenith of many globally hegemonic concepts such as nation-state, democracy, and sovereignty. While secular and rational in its aspiration, the written constitution is comparable to religious texts such as the Bible in its formidable community-constituting and faith-generating capacity. ${ }^{1}$ Borrowing the word "miracle" from Catherine Drinker Bowen that she uses to characterize the 1787 Philadelphia Constitutional Convention and its subsequent formative impact in the United States and the rest of the world, the constitution as a genre has miraculous transformative power. ${ }^{2}$ Empires certainly existed in the past, and rulers issued laws, but the kind of participatory large-scale nation-states dominating the contemporary world would not have materialized without the written constitution - a genre claiming to be the law of laws.

One important aspect of studying the constitution as a genre is to treat it as a species, something that Zachary Elkins, Tom Ginsburg and James Melton do in their project reported in the book The Endurance of National Constitutions. They gather 935 national constitutions written between 1787 and 2005 in their archive, note the operational life of each constitution, and analyze the constitutions to identify the design factors contributing to the longevity/mortality of the documents. Given the short life span of most constitutions (19 years on average, as they

\footnotetext{
${ }^{1}$ See constitutional scholar President Barack Obama's farewell speech delivered on January 10, 2017 for the connection. The speech demonstrates the similarity in priestly sermons and ceremonial presidential addresses not only in terms of the style of delivery but also in terms of the moral imperative of following the original creeds (Christian in sermons; liberty, selfgovernance, and national solidarity in presidential speeches) involved in them.

${ }^{2}$ Bowen uses the word "miracle" to describe the 1787 Constitutional Convention in Philadelphia. Certainly, she does not use the word to expound the power of the genre that the convention and ratification process experimented for the first time at national level. "Miracle" for Bowen rested on the convention's capacity to resolve contentious issues by agreeing on the Constitution.
} 
report), and the recent phenomenon of many countries writing new constitutions, they want to discover the underlying pattern of long-serving constitutions so that the discovered deep grammar can be transplanted in the unstable places of the world. ${ }^{3}$ While they do not deny the role of environmental factors, they claim that "design factors" such as "constitutional flexibility, the inclusiveness of the constitution, and the level of detail and scope of coverage in the constitutions" significantly determine the life span of a constitution $(2,8)$. Undoubtedly, their project is valuable for any comparative study of constitutions, but their focus on finding textual pattern has undermined the role of context; the written constitution emerges as a species, but their decontextualized approach has stripped the constitutions of their rhetorical dimension. Instead of studying specific performances of a constitution in a rhetorically active context, their effort concentrates on finding the essence of the so-called best constitutional texts. They approach their study as structuralists rather than as rhetorical genre analysts.

Certainly, Elkins, Ginsburg, and Melton have not claimed to be genre theorists. Nevertheless, even the most dominant genre approach to the constitution has been to characterize a constitutional text in relation to literary genres as if only literary forms have the distinction and prestige of being genres. For instance, Ulrich Schmid finds four different Russian constitutions reflective of "drama, fairy tale, gospel, [and] performance" in their forms ("Constitution and Narrative" 431). In another study, he presents the 1814 Norwegian Constitution as poetry ("The Norwegian” 78-79). An exception in this regard is Karen Gammelgaard's book chapter: While she still focuses on textual features of four nineteenth-century European constitutions substantially, she borrows from the genre theorist Carolyn Miller in her attempts to find the

\footnotetext{
${ }^{3}$ The Longevity of national constitution is mostly a desired attribute, although Thomas Jefferson at one point in 1789 thought that each generation should write its own constitution in every 19 years to uphold the proposition of popular self-governance.
} 
functions of the constitution as a genre. Based on those textual characteristics and the political implications of those textual features, Gammelgaard discovers recurring recognizable "discursive patterns" in the constitutions, presenting it as evidence of the constitution as a "transnational genre" (106).

In this scholarly context, where the written constitution has not been studied substantially from rhetorical genre perspective, I ask the following questions: why and how did the written constitution emerge in the United States in the eighteenth-century? What functions did it perform for the founding generation? Does the foregrounding of the Constitution as a genre enlighten us with new insight about the role of the word in the foundation of the United States? How has the genre performed in non-western contexts with the written constitution's hegemonic global ascendency in the subsequent centuries? What can the writing teachers understand about the dynamics of large, public collaborative writing projects from the constitution writing processes of some of the countries analyzed in this dissertation?

What I am trying to do in this dissertation is to study the written constitution as a species, but not as a decontextualized, rhetoric-free essentialized form; as a genre performing particular functions, but not exactly as the manifestations of grand motives represented by literary forms; as a pliable text type embodying certain ideological imprints, yet not as the fixed ideology restricting its uptakers to employ it for their own purposes; and, as something brought into being by historical forces, but also as something guiding the course of history. I'm using the noun 'uptakers' above as the agents of doing "uptake" in the sense Ann Fredman has theorized. As Anis Bawarshi comments on Fredman's idea, uptake of a genre is about "selecting a set of possibilities and not others" ("Beyond" 246). This approach is akin to what Bawarshi calls "genre performances" (italic original; "Beyond" 244). Using Bakhtin's distinction between a 
sentence and an utterance, where "while sentences are defined grammatically, utterances are defined performatively," Bawarshi theorizes genre performances as the actual iteration of a genre in real time and situation ("Beyond" 244). This approach lends me an opportunity to think about the written constitution as a transnational genre with certain genre parameters yet with the variation in its uptake across time and place. Indeed, the analysis of the genre performances of the written constitution becomes incomplete without referring to the American experimentation in the late eighteenth-century because it functions as the first major yardstick in the applicationif not the origin — of the constitution as a genre.

Indeed, a long textual and generic history such as legal contracts, government ordinances, and treaties among nations propelled the birth of the written constitution. In themselves the ideas that that a piece of written text can be binding of human conduct and that violation of the oath in the text/contract is punishable are revolutionary cultural feats in human history. The ideas suggested that a written document can be instrumental in forging collective human subjectivity and in realizing large-scale communities such as the nation-state. The ideas catapulted a written text to the center of persuasive collaborative activities because it would function as the anchor, proof, and discipliner of those activities. This collective ability—or, perhaps, human fallibility to misrecognition and false identification with symbols as Jacques Lacan has theorized—-to hold faith on a written text lies at the core of how the constitution and related genres function pragmatically.

However, while it may have taken thousands of years for achieving the evolutionary collective human faith on the written text, the period between 1776 and 1787 — as Robert Ferguson notes - served as a great experimentation of the written constitution across various American states that sharpened the skills of the drafters of the federal Constitution, giving birth 
to the science of written constitution, a form that would subsequently dominate the globe (137). Americans had certain national philosophical aspirations and historical anxieties during the period. For instance, they feared that their hard-fought and newfound liberty could be shallowed by the corrupting influence of power. As Gordon Wood has analyzed, American revolutionaries borrowed the classical model of virtue, which led them to think of "a republic of equal, active and independent citizens [where]...the loss of independence and virtue was corruption" (104). The written constitution for them thus was a tool to restrict the power with a set of laws so that the virtue in the leaders could remain intact safeguarding the liberty of the people. This vision necessitated the clear codification, definition, and division of power-and perpetual check-andbalances - among the organs of the government. The practice of introducing the constitution would be gradually the norm in the world in the subsequent period.

As we can expect because of its centrality in the modern nation-states, the written constitution has been one of the most commented scholarly subjects, generating a plethora of books, articles, and conferences. However, within rhetoric and composition scholarship, the constitution as a genre has not attracted much attention. Among the limited studies, perhaps the most extended commentary comes from Kenneth Burke. He, in the last chapter of A Grammar of Motives, characterizes the Constitution of the United States of America as "a set of [idealistic] wishes more or less at odds with one another" (375). Given the impossibility of creating unanimous consensus, a constitution is bound to embody a variety of — and often contradictorywishes of its constituents for it to be an acceptable, governing document. Burke thus calls the Constitution "a calculus of motives" or an "anecdote summational in character...wherein human relations grandly converge" (Grammar 325, 324). He points out the unavoidability of contradictory impulses in the Constitution. For instance, he highlights the contradiction between 
public right and private duties: "A public right, for instance, 'necessarily implies' a private obligation or a private jeopardy; a private right 'inevitably' implies a public obligation or a public jeopardy" (Burke, Grammar 375). With this theorization, Burke emphasizes "the fiction of positive law," an assumption that the Constitution is a coherent body of laws written in stone (Grammar 363). Then, for him, the question becomes, if it is a bundle of contradictory wishes, how does the Constitution function? Since the Constitutional text becomes prominent mostly in the contexts of court litigations where both litigants in question seek evidences from the text to justify their position (otherwise there would be no case or argument at all), what wish gets to be rewarded depends on the "Constitution-behind-the-Constitution"- the body of precedents and prevailing dominant values (Burke, Grammar 362). The Constitution for Burke thus is a living document—open to new constructions, and continuously rewritten by judicial interpretations. Expanding on Burke's argument, Virginia Anderson reads the Constitution as a postmodern text, "a metonymic constellation of contingent possibilities relying on contextual interpretation for implementation and realization" (276). She further writes, "the Constitution is a bundle of incipient antitheses waiting to be highlighted rhetorically in litigation, then reconstructed rhetorically through paratactic reassociations (Anderson 276). While Burke and Anderson provide us with a rich rhetorical angle and many of their ideas are transferable to the analysis of other constitutions, their work primarily is on the U.S. Constitution, not on the constitution as a genre.

Conducted at a crucial historical moment when the conception of sovereignty was shifting from monarchy to people, the American experimentation with the written constitution established the idea that politics can be a game among sovereign citizens with their self-authored rules. Many countries followed American example, sometimes putting the genre for a deeply 
consequential performance. For instance, the written constitution may bring a country into being.

As William Warmer and his cowriters proclaim, the constitution is "the thing that invented

Norway" (21). If it does not reach to that extreme always, the written constitution as a

performative genre at least reconstitutes the government and power relationship in a country. ${ }^{4}$

While the genre still imposes some of its ideological and procedural features from its

earlier enunciations, with its global adoption and adaptation, the written constitution has

performed many context-specific functions. John Swales observes, "When these [genre]

performances proliferate, genres tend to drift through time and geographical space, partly

inherently and partly as a result of intertextual acceptance and rejections" (14). Certainly, it is

virtually impossible to analyze — let alone identify — all the functions performed by the

constitutional genre.

In the rest of this dissertation, I read the constitutions of the United States, the Cherokee

Nation and Nepal by placing them in their specific historical contexts with the view of what functions the genre performed, what purposes it served, and how the uptakers used it. My approach is symptomatic rather than exhaustive: instead of reading all articles in the selected constitutions, I highlight a few dominant functions and motivations, accentuating major tendencies rather than generating a definitive total narrative on the topic. About genre analysts, Swales writes, "The work of genre analysts is to track these textual regularities and irregularities and explain them in terms of relevant and pertinent social circumstances and the rhetorical demands they engender" (14). While I am conscious of the pitfalls of forcing texts and contexts

\footnotetext{
${ }^{4}$ See Akhil Amar's long commentary on the preamble of the U.S. Constitution (5-53). He emphasizes the performative function of the constitution by highlighting the democratic ratification process and the words in the preamble such as "do ordain and establish this Constitution." The constitution for him is akin to vows, such as 'I do' in weddings. Also, see J.L. Austin's interdisciplinarily influential, groundbreaking theorization, particularly the first chapter (1-12), on the difference between performative and descriptive functions of language.
} 
within the existing theoretical models, my approach in this dissertation certainly is that of a genre analyst - not least because the quest of the genre performances, as Bawarshi defines, relieves the analysist from any theory confirmation practices.

\subsection{Rhetorical Genres, Symbolic World, and Social Performances}

Before delving directly into the genre of the constitution, a brief compendium of Rhetorical Genre Studies (RGS) — the major theoretical tool of my study — is in order. While scholars have studied genre for centuries in a variety of contexts, Rhetorical Genre Studies developed in North America in the late twentieth-and early-twenty-first centuries - particularly in the works of K.K. Campbell, K.H. Jamieson, Carolyn Miller, Charles Bazerman, Amy Devitt, David Russell, and Anis Bawarshi—has transformed the idea of genre "from a descriptive to an explanatory activity, one that investigates not only text-types and classification systems, but also the linguistic, sociological, and psychological assumptions underlying and shaping these texttypes" (Bawarshi, Genre 17). The most influential shift appeared when Carolyn Miller defined genre as "typified rhetorical actions based in recurrent situations" (159) in her seminal 1984 essay. By defining genres as "typified rhetorical actions," Miller geared the genre theory from its traditional formal orientation to rhetorical functions, from the quest of identifying salient features of a genre form to the performative functions of a genre.

Following Miller, rhetoric and composition scholars started rethinking and redefining genre. One comprehensive and powerful articulation of the definition of genre comes from Charles Bazerman in his "The Life of Genre, the Life in the Classroom." He writes,

Genre are not just forms. Genres are forms of life, ways of being. They are frames for social action. They are environments for learning. They are locations within which meaning is constructed. Genres shape the thoughts we form and the 
communications by which we interact. Genres are the familiar places we go to create intelligible communicative action with each other and the guideposts we use to explore unfamiliar. (19)

Certainly, genres for Bazerman are "social actions," but they go beyond just being the momentbased rhetorical actions. Human beings — as "symbol-using" and symbol-living animals_ dwell in the world of meanings constructed by symbols such as language and cultural codes (Burke, Language 3). ${ }^{5}$ Such a state of existence requires us to understand, define, and act on social expectations because the symbolically constructed world is a structure made up of shared meanings and forms. From an individual perspective, individual actors may have an opportunity to modify the structure through their actions, but the symbolic world precedes the person in existence. Participating in that world entails learning and performing genres. Thus, as Bazerman defines, genres are "forms of life, ways of being", "frames for social actions", "environments of learning", "locations within which meaning is constructed", or the "shapes" of thoughts and communication. For an individual, acting in the symbolic world-knowing what to do, where to do it, whether to do it, how to do it, or even why to do it-rests on his or her acculturation with the genres that constitute the world. Even the sense of historical exigency emanates from the existence and understanding of a genre that allows the participants to think of something as an exigency. Bawarshi writes, "As cultural artifacts, they [genres] embody exigencies, and in using

\footnotetext{
${ }^{5}$ This idea is as old as it is new. Aristotle meant it when he defined men as social animals. Structuralism and poststructuralism as developed in the works of Ferdinand De Saussure and Jacques Derrida may have differences about the nature - particularly the degree of coherenceof symbolic system, the primacy of symbolic structure in the human world is their essence. When Judith Butler defined gender and sex as social performances as historically evolved and individually performed symbolic actions, she was deepening the prominence of symbolic function in human life, highlighting how even biological factors are coopted by symbolic needs in the evolutionary process.
} 
genres, we enact and reinforce these exigencies as recognizable, meaningful, consequential actions" (Genre 41). Genres are not only tools of social actions; they are also equally determining of the need of the performance of those actions.

To emphasize the same point further, genres bring the things into being. For instance, the idea of sovereignty might have gone through certain modification in centuries as it travelled through various contexts and genre conventions, but it could be a conceptual being because of certain genres articulating it. In the modern time, it is through the written constitution and other related legal genres, sovereignty became a tangible workable concept regulating people's lives and governments' behavior. Genre thus is "constitutive rather than merely regulatory" (Bawarshi, Genre 24). Bawarshi further writes, "genre does not simply regulate a pre-existing social activity; instead, it constitutes the activity by making it possible by way of its ideological and discursive functions" (italic original, Genre 24). Genre, from this perspective, is not just a tool of social actions, but constitutive of actions themselves.

Theorizing this way, as the structure shaping human actions, genre may sound like a completely deterministic force, stifling the users' creative possibilities. But, as Paul Prior writes, "genres should be understood not as templates but always partly prefabricated, partly improvised or repurposed" (17). Undoubtedly, genre — as "typified rhetorical actions based on recurrent situations"- embodies ideological imprints; being based on convention, instant recognition, and a sense of continuance characterize a genre. However, as Prior suggests, when the same genre is taken up in another rhetorical situation, the new setting adds on its own peculiarities, giving genre improvisational quality. While the fundamental purpose of using the genre in a new situation may be similar to the one from its use in earlier situation, that it has to perform context specific function repurposes the genre automatically. Metaphorically, the ideological dimension 
of genre is comparable to the DNA in a biological organism: DNA is something fundamental to an organism, defining its characteristics, but evolutionary mechanism transforms DNA as well because of the organism's adaptive process in the environment. Deepening the metaphor further, while a constitution shares the genotype of the genre, it also manifests itself in the form of a phenotype, the form influenced by the environment. Thus, genre certainly carries on its predeterministic quality, but it is equally open to modification in order to be contextually relevant in different situations.

The transformation possibilities in a genre spring from various sources. First, as Bazerman has written, a genre does not work in isolation: genres function within "genre systems" of "interrelated genres that interact with each other in specific settings" (Bazerman, “Genre Systems” 97, 99). The genres participating in a genre system form various kinds and degrees of combination and permutation depending on the dynamics of the setting. The settingas a thick context - is composed of many factors from long-term historical and cultural aspects to momentary power relationship among actors, determining how the participating genres interact among each other within the evolving genre system. ${ }^{6}$ While the genre exerts its influence from the past in the new setting, the new setting also modifies the genre, appropriating it for that setting. Bazerman writes, "It [genre performance] embodies the full history of speech as intertextual occurrences but attending to the way that all the intertext is instantiated in generic form establishing the current act in relation to prior acts" (“Systems” 99). Genres are tools "within which communicants instantiate and reproduce situated desires, practices, relations, and subjectivities" (Bawarshi, Genre 115). Second, but not entirely different from the first point, the

\footnotetext{
${ }^{6}$ See Geertz, particularly the first chapter (3-30), for the importance of "thick description" to appreciate the complex totality of a culture. Setting certainly is more than a culture because a setting adds on momentary actors, instruments and purposes in the long-standing culture.
} 
modification also comes from genre's place in what David Russell calls an "activity system," which he defines as "any ongoing, object-directed, historically conditioned, dialectically structured, tool-mediated human interaction" (510). In his intricately rich definition that borrows from Russian structuralism and Bakhtin's dialogism, Russell emphasizes on the contextualization of genre. Genres are part of human activity in the world: as conceptual and functional tools, they retain their past characteristics while undergoing change through their participation in an activity. As a part of a dynamic activity system, genres allow the system to work on them, but simultaneously, they contribute to the particular instantiation of the activity system as well. Synthesizing them together, Bazerman's “genre systems" theory and Russell's "activity system" establish genre as a context-driven dynamic functional tool that works in a system of complex combination and permutation with other genres.

\subsection{Constitutional Genre, Authorship and Sovereignty}

Exemplified first by the ratification process of the American Constitution in the late 1780s and the ideological underpinning such as popular sovereignty invested in the process, authorship has come to be a core aspect of the constitutional genre. As the main law of the land, a national constitution holds the power to de/legitimize people's actions, but the greatest test of a constitutional text rests on its ability to gain self-legitimization. Since no text is providentially sanctioned to be the ultimate law, a constitution depends on the elements of its own genre convention for its transformation from a type of a text to the legitimate authority with power to dictate the ways of the people and institutions. It is primarily through constitutional authorshipitself a constructed phenomenon within the genre convention - through which a constitutional text establishes it governing mandate. In this regard, the constitution as a genre is comparable to an official letter: while it does not always matter who writes the text exactly, both genres need 
proper signature and seal for their authentication. Indeed, whether the text passes the test of being an appropriate governing document depends on whether it is proposed, drafted and ratified by the body of people considered to be a legitimate authority for the task. Proper authorship is thus the mechanism for transforming a set of words into the hallowed document functioning as the main law of the land. However, despite this centrality, the constitutional authorship is a complex historical production that does not serve uniformly across history and locations.

The observations and claims made in the previous paragraph generate important questions: How did the idea of constitutional authorship originate? How did it become possible to think of a nation having a selfhood and authorship with the ability to write its own laws, particularly in the post-monarchial era? In what follows, I argue that the emergence of constitutional authorship should be tied with the historical transformation in the practices and conceptions of sovereignty, especially during the Enlightenment. In the process, I will also demonstrate how the analysis of the genre-function of the written constitution facilitates the understanding of such historical transformation.

Previously, in the pre-Enlightenment period, while the exact terms of practices differed from one location to the other and from one period to another within the same location, the predominant political mode accorded sovereignty to the monarch. ${ }^{7}$ Not only did the king possess sovereign immunity but also issued laws because of his divine power, an ideological disposition that made the king more a medium — an "agency" rather than an "agent," using the terms from

\footnotetext{
${ }^{7}$ Louis XIV's famous statement “The State? I am the State?" represents an interesting moment in Thomas Carlyle's history of the French Revolution (8). While the king still claims his divine authority with the statement, the world around him has moved ahead. Thus, instead of an affirmative cheering from his courtiers, the statement is "replied with silences and abashed looks" (Carlyle 8). In this historical narrative, Carlyle captures the transformative moment in the practices of sovereignty in the French court as represented both by the muted nonverbal cues and expressions of the courtiers as by the roaring thunder of the dying king.
} 
Burke's pentad - rather than the author of purported universal (because they were interpreted as coming directly from the god) political and social laws. ${ }^{8}$ In this ideological imagination, the king's sovereignty emanated directly from the upper sovereignty—-the ultimate source — placing the king at the pinnacle of the stratified feudal hierarchical order while making everybody else his subjects. In the extreme form of this practice, the monarch concentrated power without having to divide, categorize, and define it into various modern familiar terms such as legislative, judiciary or executive. Certainly, his (sometimes, her) majesty's contemporary critics and commentators remarked whether a particular monarch was an ideal one, ${ }^{9}$ and, certainly, in reality, the king delegated his power to clever courtiers, who exercised the king's power more than the monarch themselves. Nevertheless, since the kingdom was conceived to be an extension of the king's body, thus locating sovereignty in the single authority of the monarch, the dominant contemporary conception of sovereignty accorded theoretical and political unity to pre-modern nations.

The forces that led to the Enlightenment challenged this conception of sovereigntydissociating it from the king, and thus preparing for a different kind of political arrangement. ${ }^{10}$

\footnotetext{
${ }^{8}$ See Burke's Grammar for his theorization of pentad.

${ }^{9}$ The king was thought to be an executor of universal justice.

${ }^{10}$ Here is what we should not forget when we think about sovereignty. First, the predominant mode of sovereignty that we think about, theorize, and practice today in academic, legal and political settings comes not entirely, but dominantly from European tradition of kings, republicanism, and the Enlightenment. As practiced within this tradition, the current dominant practice of sovereignty, which is not fully coherent in its motives and composition, embodies contradictory impulses - one coming from the king's desire to be the imperial master with total hold upon as many people and resources as his power could amass, and the other one coming from the individual's natural rights and justice tradition that was developed to confront the king's power within national setting. In a post-monarchial phase, the state tries to assume the premodern king's sovereign power but assuring that the state's sovereignty is for securing the individual citizen's sovereignty. This version of sovereignty-rooted mostly in legal, procedural discursive and institutional framework - dominates the political imagination today because of the globalization of written constitution and the nature and ideological positions girding the genre.
} 
Now modern nation-states made up of print culture and written constitutions, as Benedict Anderson has argued, replaced the kingdom, making citizens' nationalist consciousness rather than their association with the king as the connecting fabric of the new disposition. In the modern nation-states, citizens — not the king — became the major actors. As Richard A. Ryerson has argued, the notion of modern republic with sovereignty in people itself was an embryonic idea during the Enlightenment period (qut. in Arnold 131). Thinking from the perspective of sovereignty, this new cultural imagination lost the unity of sovereignty possessed by the premodern king-centered nations. Now both the state and the citizens were conceived to be sovereign entities: the state would enjoy the power of sovereign immunity that the king previously possessed, while individual citizens also would have sovereignty with their fundamental natural rights guaranteed by the written constitution and bill of rights This discussion demonstrates that an analysis of the genre-function of the constitution help us see the connection in the construction of and relationship among citizenship, sovereignty and authorship.

For illustration, the Declaration of Independence and Abraham Lincoln’s Gettysburg Address represent two unique moments capturing this transformation and the tension between the two forms of sovereignty. The Declaration proclaims the sovereignty of individuals as inherent fundamental rights endowed by the creator, as "self-evident" truths, not requiring any

The juggernaut of this mode is so powerful that it has become almost impossible to think of other forms of sovereignty without referencing it effectively. Certainly, postcolonial and indigenous intellectual projects have tried to find, articulate and forward alternative forms of sovereignty. But, 'Once absorbed into the 'chronopolitics' of the secular West, colonized space cannot reclaim autonomy and seclusion; once dragged out of their precolonial state, the indigenes of peripheries have to deal with the knowledge of the outside world, irrespective of their own wishes and inclinations" (Miyoshi 730). Alternative vision of sovereignty and political organization demands what Dipesh Chakrabarty calls, "provincializing Europe," meaning putting the dominant western thought into its own place for imagining different forms of political sovereignties and thoughts (3-27). 
external justification. ${ }^{11}$ Since the Declaration's immediate purpose was more the colonies' independence from the British Empire rather than the formation of a new state (the United States), the document does not grant much power to the state structure. The Declaration proclaims, " to secure these rights [the unalienable rights of individuals], governments are instituted among Men, deriving their just powers from the consent of the governed; that whenever any form of government becomes destructive of these ends, it is the right of the people to alter or to abolish it." In this vision, the state's sovereignty remains subservient to the citizens' sovereignty. But the Declaration's vision of the supremacy of the citizens' sovereignty —also reflected in the 1781 Articles of Confederation-over that of the state proved to be a too idealistic proposition, a shortcoming that the 1787 Constitution proposed to overcome with the provision of an effective and strong federal government. The events between the dates of the Declaration and the Constitution's enforcement demonstrated that the viability of citizens' unalienable rights rested on the state's ability to secure them. This realization made the Founding fathers conceive the state (national government) as a sovereign body — an entity larger than the sum of its individual citizens. Lincoln's Gettysburg Address — delivered almost eight decades after the Declaration to commemorate the sacrifice of the dead soldiers in the Civil War- in a sense represents the pivotal moment when state sovereignty holds the primacy.

While Lincoln reiterates the Declaration's idealistic vision stating that the American government was "of the people, by the people, and for the people," for him the major question of the Civil War was about "whether that nation or any nation so conceived, and so dedicated, can long endure." The point is this: the state (conceived in a certain way, of course) itself was

\footnotetext{
${ }^{11}$ While the repeated political, legal and cultural assertions of this statement might have made this conception a (positively) hegemonic influence almost to the point that we may feel as if individual rights were inherent natural rights not requiring any justification, a momentary critical pause reveals that even the idea of natural right is a historically constructed phenomenon.
} 
sovereign; individual sacrifice was worth preserving the state so that it could safeguard the citizens' sovereignty. Therefore, in this formulation, the sovereignty of the state neither is the composite of its citizens' sovereignty, nor is it always defined only in relationship to its opposition to the sovereignty of other nations. In an ideal setting, in the way the Declaration wishes, the state tries to bear no sovereignty at all as if its only function were to preserve the sovereignty of its citizens. However, in practice, as the instance of the Civil War suggested, the state starts assuming full sovereignty, asking for the sacrifice of its citizens for its maintenance. From this logic, the state sovereignty serves as a structural necessity to guarantee citizen's sovereign rights. Because of such necessity, citizens' highest duty becomes their willingness to terminate their life for the sake of national sovereignty.

Giorgio Agamben in his books has influentially theorized this conundrum - the unstable relationship between the state and citizens in the practices of sovereignty. Agamben demonstrates a pattern in the responses of western liberal states when they confront political crises, particularly those that challenge their ability to maintain law and order. During the crises, the governments suspend regular laws, declaring the state of exception. Executed by using the force of the law to suspend certain other parts of the law (mostly, the fundamental rights of the citizens guaranteed in constitutions) itself, this ability of the sovereign - the state now, replacing the king in pre-modern time-represents the supremacy of the state's sovereignty over the citizens' sovereignty. The suspension turns certain people into what Agamben calls "bare life" or "life in general" or "pure being" without any legal protection (Home 66, 66, 182). The bare life is the Homo Sacer, the accursed one that the state or anybody can kill without any punishment. Deprived of any human epistemic, political, and cultural attributes, the bare life becomes an expendable "element that, in the exception, finds itself in the most intimate relation with [state] 
sovereignty" (Homo 67). During the state of exception-which occurs regularly contrary to what the name suggests - democracies convert themselves not into obvious "dictatorship but a space devoid of law, a zone of anomie in which all legal determinations are deactivated" (Exception 50). Cumulatively, Agamben exhibits how the state's propensity to suspend the protective regular laws — of those that convert bare human lives into sovereign citizens with political rights_inversely manifests the idealistic vision of sovereignty represented in the texts such as the Declaration.

This struggle expressed in the tension between the wishes of the Declaration and the spirit of the Gettysburg Address captures the ambiguity in the modern conception of sovereignty - a conception that presents individual sovereignty as intrinsically innate yet incapable of self-sustaining, thus requiring the protection of an external sovereign power. ${ }^{12}$ Emanated from the bifurcated location of the modern sovereignty, this ambiguity poses a unique challenge of connecting two forms of sovereignty into one workable system, into one agency, one will for it to be functional. I argue that one major political technology for addressing this challenge has been the constitutional authorship. In constitutional authorship — and the national governing mandates created through periodic elections - not only citizens practice their sovereign rights by participating in the creation of the laws that govern them, but also create a collective will for the nation.

Before elaborating how constitutional authorship tries to unite both forms of sovereignty into single workable mechanism, an explanation of the historical coevolution of authorship, individuation and popular sovereignty is in order. As Roland Barthes has argued, "The author is a modern figure, produced no doubt by our society insofar as, at the end of the middle ages, with

\footnotetext{
${ }^{12}$ Irony lied in the Civil War's connection with slavery; saving the Union also meant abolishing liberty, restoring the intrinsic sovereignty of the enslaved persons.
} 
English empiricism, French rationalism and personal faith of the Reformation, it discovered the prestige of the Individual, or, to put it more nobly, of the 'human person'" (142-143). Although Michel Foucault does not concede to Barthes' death of the author thesis, he concurs with the basic proposition that authorship is a modern historical construct with some functions (1628-36). Thinking from the perspective of constitutional genre and transformation of sovereignty that the emergence of the genre accompanied, I am suggesting that authorship and citizenship manifested two different facets of the same emerging sovereign individual. Being an author and a citizen assumes the inherent sovereignty of the individual assigned with the privileges of exercising and expressing one's uninfluenced core values. The two concepts evolved together: as the historical process of transferring sovereignty from the king to the citizen was undergoing, political philosophers were refining the idea of the individual's inalienable natural rights, while authorship was also seeing its formation and ascendency simultaneously. ${ }^{13}$ The same cultural forces that created the idea of a citizen endowed with sovereign free will necessitated the idea of authorship. Increasingly, the individualizing process - creating the concept of a person as an individual endowed with independent cognitive, emotional and intuitive power free from the rest of environment — revived the classical republicanism depositing sovereignty on individuals_ushering in the need of new kind of politics and culture. ${ }^{14}$ To further emphasize the point, striping sovereignty of an individual removes her citizenship as well as the possibility of having an authorship. A bare body without fundamental rights is neither a rightful witness in a court of law nor capable of accessing her rational self for authorial expression. Sovereignty therefore underpins both citizenship and authorship.

13 Think of John Locke's political treatises, for instance.

${ }^{14}$ Chapter one will demonstrate this connection extensively, especially in connection with the works of Bernard Bailyn, Gordon Wood, J.G.A. Pocock, Michel Warner, and Mark Garrett Longaker. 
However, as theorized above, the historical development in the conception of sovereignty during the Enlightenment did not transfer the earlier sovereignty of the king to the citizen alone. The state also emerged as a sovereign entity that needed the process of national individuation. In the past, the king could exercise the sovereignty of the state. Now, that means, the nation had to have a body and selfhood with the ability to make decision, with a single will. Using Cartesian paradigm, the nation needed a rational, thinking agency with the power of self-determination to be a sovereign self. Converting a nation — as massive as the United States in the Eighteenthcentury — into single-bodied thinking mechanism with the ability to make pointed decisions and deliberations needed some craft, a procedure. Constitutional authorship — and the mandate created through periodic elections for instituting governments after the enactment of the Constitution-became the mechanism of such individuation. To meet this expectation, cultural imagination would increasingly cast nation into the image of human body. ${ }^{15}$ Now, this conception - the idea of constitutional authorship and the governing mandate - could constitute oneness out of the chaotic mass of divergent people with a variety of interests, relationships, and power. For instance, the first unofficial moto of the United States "E pluribus unum" (one out of many), in a sense, succinctly captured the spirit of this transformation in 1782 . Now with this political craft, a sovereign nation could decide on thorny issues with the precision of even a

\footnotetext{
${ }^{15}$ Medical rhetoric is particularly illustrative of the metaphor of nation-state as a body. In one manifestation, medical discourse treats, "the body as nation state at war over its external borders, containing internal surveillance system to monitor foreign intruders" (Martin 410). In this imagination, human body and national body share similar kind of vulnerability: external agents can infiltrate them, jeopardizing their health and sovereignty. However, the definition of disease and externality do not always have same markers. Demagogues and fascist purists often utilize the same body-nation metaphorical vision to malign and exterminate vulnerable groups of people within the boundaries of the nation, characterizing them as diseases eating the national purity and selfhood. For instance, Andreas Musolff has demonstrated how "Nazis used [the imagery of the body-politic) to legitimize their genocidal policies [by treating a group of people] ... as a parasites" to the body of the people (2-3).
} 
single digit - mathematically by counting the votes cast by sovereign individuals. Constitutional authorship as a political technology thus becomes functionally meaningful in its capacity to bring both forms of sovereignty together for political action: It allows sovereign citizens to exercise their power in the formulation of the national law; simultaneously in the process, it also creates a national selfhood, a prerequisite for a sovereign body in the world governed by Cartesian cultural imagination.

Undoubtedly, this is not the only way through which constitutions are enacted in the modern world. ${ }^{16}$ But this view of constitutional authorship that combines the visions of popular sovereignty, democracy, and citizens' self-rule serves as the dominant ideology for modern politics. For instance, the same ideology of constitutional authorship governed Nepali revolutionaries' mindset hegemonically when they demanded for the people-written constitution as they mounted many political movements and revolutions for seven decades in the second half of the twentieth-and early-twenty-first centuries. Same ideology of constitutional authorship is evoked when Japanese conservatives characterize the 1947 Japanese Constitution "as a foreign imposition" because it works as "a strategy for depriving the document of legitimacy and undermining popular support for the provisions that formally limit country’s military capabilities" (Law 240). The idea of popular collective authorship is thus a strong legitimizing force in the genre of the written constitution.

But what is important to note is that the constitutional authorship itself is the product of what Bawarshi calls "genre function” (Genre 19-23). As Bawarshi defines, the concept of genre function avoids the limitations inherent in "author function," which Foucault theorized not as an expression of an individual's interiority, but as a function, particularly of classification of

\footnotetext{
${ }^{16}$ See the chapter three in this dissertation for three kinds of constitutional authorship practiced in South Asia in the twentieth-century.
} 
discourses and texts, and of rewarding and punishing of individuals for their expression. Bawarshi argues, since all texts, such as users' manuals, do not have authors but still exist in the world performing functions, the best way to understand the place and functions of the texts is in terms of genres rather than that of authorship (Genre 19-23). Building on and expanding the same concept, I argue that constitutional authorship itself is the function of constitutional genre because it is crafted, defined, and produced by the genre convention. Constitutional authorship is not a self-evident natural phenomenon; the written constitution procedurally produces the constitutional authorship. While the procedure tries to strike a balance for respecting both the individual sovereignty and the need of creating national legitimate selfhood, a particular actualization of the authorship differs from one context to the next because of the genre modification caused by kairotic and contextual factors in its particular instantiation.

This theorization leads constitutional scholarship to new directions at least in two ways. First, it changes the nature of debate on constitutional authorship within legal studies. Primarily, two views of constitutional authorship exist in legal studies of the U.S. Constitution. The originalist school attributes the authorship to the drafters of the text, emphasizing judicial interpretation should consult the relevant contemporary texts such as the Federalist Papers to decipher the original intention of the Constitution. This school contents that judges can maintain the sanctity and uniform interpretation of the Constitution only by associating the text with the original authorial intention. Doing anything else is to jeopardize the spirit of the Constitution. Libertarian legal scholar Randy E. Barnett, for instance, argues that the tradition of judicial interpretation has killed the Constitution as intended by the Founders. He stresses that the Constitution has been replaced by the "judges" constitution" (5). Stating "we the people" as fiction, he holds that "the most commonly held view of the constitutional legitimacy — the "the 
consent of the governed'-is wrong because it is a standard that no constitution can meet" (13, 3). He further argues that, "holding the Constitution to this untenable ideal both undermines its legitimacy and allows others to substitute their own meaning for that of the text" (3). On the other hand, the proponents of the idea of living constitution maintain that political and cultural positions of the time determine the meaning of the Constitution. Highlighting actual practices in court proceedings and interpretations, legal scholar David A. Struss, for instance, points how the actual text of the Constitution is rarely consulted, how the focus remains on collective body of precedents and tradition for making a decision, and how judges decide considering 'what is fair' and 'what works' rather than consulting the Constitution in the absence of a clear precedent.

As the legal and literary scholar Stanley Fish would maintain, it is the interpretative community — instead of dead founders - that determines the meaning of the Constitution. From the vantage point of the notion of the living constitution, the original authorship of the Constitutional text might have shaped the superstructure of the state such as the formation of governmental branches, citizens' basic rights, and government responsibilities. But so far as most of the time-pressing cases are concerned, it is the common law or the constitution with the 'c' (the collective body of precedents) that guides everyday court decisions. The originalist school thus assigns a definite group of people — such as those involved in the drafting, ratifying and amending - the attribute of constitutional authorship. However, from the perspective of living constitution, while individuals play roles, a set of documents and prevailing socio-political moors exerts the force in the construction of the constitutional meaning.

When constitutional authorship is interpreted as the genre function or product of the genre, the question should be more about how the constitutional authorship is procedurally produced within the genre convention rather than debating who the exact author is. When 
understood this way, this perspective, as theorized above, suggests that constitutional authorship is a historically constructed category that the historical forces - including human actorsbrought into being to respond to the rhetorical exigency of the moment when one conception of sovereignty was giving way to new form of sovereignty, shifting the vision of kingdom into the popular nation-state. As it stands now, the dominant form of constitutional authorship evolved first in the United States and was later globalized hegemonically. In this form, nor the ideas such as 'the consent of the governed' or 'judiciary interpretation' or 'the original text authored by the Founders' function with absolute force, nor they can be relegated into non-significance. Arguing for one at the cost of the other is either to commit intentional or affective fallacy or to neglect the role of founding intentions or affected interpretations. The constitutional authorship thus should be sought and interpreted as defined, developed and realized within the genre tradition. And, when authorship is conceived as the function of the genre, and when a genre is understood as composed of dynamic structures, we open the possibilities of the realization of various forms of constitutional authorship in the spectrum from the authorship constituted through an inclusive electoral procedure at the one end to the authorship dictatorially imposed by a military strongman at the other end.

Besides this opening, the shift of focus from author-function to genre-function also provides us with another insight about the unattainability of radical democratic wishes sufficiently through constitutional authorship. In fact, Thomas Jefferson, long ago at the time when constitutional genre convention was on the process of inception, observed the difficulty of translating the political idealism of popular sovereignty in practice. In his correspondence from France with James Madison in 1789, Jefferson, the composer of the lofty aspiration of Enlightenment such as "all men are created equal" enshrined in the Declaration, muses: "If every 
form of government were so perfectly contrived, that the will of the majority could always be obtained, fairly and without impediment. But this is true of no form. The people cannot assemble themselves; their representation is unequal and vicious" (634-35). As Jefferson states, let alone radical democratic will, often engineering a national governing mandate is just a forceful ritual instead of an organically originated condition. As Akhil Amar notes, the electoral system adopted by the U.S. Constitution in 1789 was as much inspired by the sublime political ideal such as the separation of power as was influenced by the fact of slavery. ${ }^{17}$ The democratic promise of the national authorship (as expressed in constitutional authorship or periodically established governing mandate), even the ratification of the U.S. Constitution was "heresthetic" in nature (Riker 9). As William Riker argues, drafters set up a situation "composing the alternatives among which political actors must choose" one of the alternatives because of the "structure of the situation to support the herestheticians" purpose" even when they were not happy with their choice (9). Simply put, the drafters gave a false either-or choice on the motion instead of allowing the citizens to modify the provisions within the document. As Robert Ferguson observes, the American Constitution could be ratified not only because of its "inevitable repository of epistemological ambiguities" and "philosophical uncertainties" but also because of the strategies of "careful circumvention of controversial words like 'national,' 'republic,' and 'federal'” $(130,137)$. This kind of postmodernist-deconstructionist critique hits directly at the heart of the promise of modernity, of which constitutional authorship is a major political technology. The numbers function crucially in establishing the idea of a legitimate constitutional authorship and governing mandate; and, they are also supposed to be objective and impartial staircases leading human societies to the lofty political ideals such as democracy, self-

\footnotetext{
${ }^{17}$ See Amar (148-59).
} 
rule, and liberty. But often electoral systems and the numbers themselves are less than perfect tools of translating ideals into practice. As a result, sometimes, the numbers and electoral procedures may function as the ideological façades buttressing the flimsy unattainable dreams. As Jefferson lamented, actualizing idealism in its absolute form is a hard proposition. Undoubtedly, constitutional authorship has been a formidable democratic feat from historical perspective. However, having to have an electoral procedure for constituting national authorship and the compromise of the two forms of sovereignty built in its structure always haunt the promise enshrined in the genre. After all, as Burke states, the Constitution is mostly "a calculous of [many] motives" or wishes rather than a representation of all wishes.

Until this point, the whole theorization has been on how constitutional authorship is crafted procedurally within a country for the legitimization of the document. But, the use of the written constitution as a genre also presents another interesting dimension, something not imagined to be within the boundaries of the genre of a national constitution.

Constitutional authorship is also used to claim national sovereignty. When the Cherokee Nation adopted the written constitution in 1827, certainly the constitution, as expected, brought a new form of government. However, since the prime motivation for the adoption of the genre then was to resist the impending removal, the Cherokees found in the genre-particularly their ability to author their constitution — a site of articulating, defining and demonstrating national sovereignty. The constitution for them was a tool of expressing national sovereignty, a defiant posture of having an impregnable independence posed to the external world. By including a statement on territorial boundaries of the nation and the sources of those boundaries as determined by the nation's treaties with the United States in its first article, the 1827 Cherokee Constitution also evoked the U.S. Constitution for the inviolability of the nation's territorial 
boundaries. The approach activated both the power of the constitutional genre that the Cherokees were instantiating and the exact statement in the U.S. Constitution regarding the sacred obligation of the federal government to honor the treaties. This activation not only reconstituted (because the adoption of Euromerican genre convention refashioned the nature of the Cherokee national sovereignty) but tried to defend Cherokee national sovereignty. While the circumstances were different, the 1962 Constitution of Nepal was partly internationalist in its perspective as well because its author, king Mahendra, used the genre to assert his - and thus the nation's power - to write any kind of constitution without external pressure. Not so enthusiastic to provide sovereignty to the citizens as the 1962 Constitution vested sovereignty in the king literally, this application of the genre constituted and claimed the sovereignty of the nation, defined largely in terms of the country's capacity to author its own constitution. These examples illustrate that constitutional authorship has practically become the site of articulating national sovereignty for the countries facing external pressure against their self-determination.

Being based on these theoretical positions, this dissertation examines the constitutions of the United States, Cherokee Nation and Nepal. Chapter one concentrates on the U.S. Constitution, particularly arguing that the genre of the written constitution provided the United States an opportunity to externalize the norms of republicanism, articulating them not only as the personal matter of subjective deliberation but also as objectively measurable conducts open to observation, analysis, and judgement by an external authority. Based on the idea of individual virtue, classical republicanism predominantly had a subjective spiritual dimension. As embodied in the image of Roman political leader Cato, whom George Washington admired, classical republicanism emphasized qualities such as austerity, service, and sacrifice, the qualities that could align well with New England puritan tradition in the eighteenth century. While Americans 
venerated the republican qualities, they knew that the history was not kind to republics. Power corrupted the virtue, catapulting the republics into ruin. Thus, they could not constitute a strong national government after the Independence in 1776 because the concentrated power far from their locality posed an imminent threat to their liberty. They instead stuck with the 1781 Articles of Confederation that bestowed sovereignty in the local and state governments. However, the historical exigency demanded a strong national government to protect the newfound liberty itself. The compromise was the 1787 Constitution: they could have a national government but limited by the power described in the words of the document. Now, not only the people holding public offices had to be elected periodically so that the constituents could examine whether the power had corrupted their virtue, checks-and-balances among the independent organs of the government became the norm of the new disposition. Influenced by scientific descriptivism of the Enlightenment, the constitution-based politics made public conducts objectively examinable attributes. Instead of having to contemplate internally, one could now check the words of the Constitution to determine whether they have observed the high ethos of republican virtue.

The second chapter focuses on the 1827 Cherokee Constitution. Borrowing from and expanding on Kenneth Burke's theory of identification, I argue that the Cherokee adoption of the genre of written constitution in early nineteenth-century to constitute their nation - and their use of the Constitution to claim their progress according to the spirit of the U.S. policy of Indian Civilization - was a part of the Cherokee politics of identification. By adopting the written constitution and western institutional paraphernalia, the Cherokee Nation claimed its relation of identification with the United States. The nation claimed it had progressed enough, with the logic that its resemblance with the United States required the United States to recognize the Cherokee Nation. Amidst the threat of imminent removal from their ancestral homeland and the 
increasingly influential ideology of hierarchy of civilizations that placed Native Americans at a lower rank often portraying them as incapable of rational deliberation, the Cherokees found in the written constitution a space of articulation for their national sovereignty in the terms that United States could recognize. Since the motive of the adoption of the Cherokee Constitution can be revealed only by placing it in the context, I read primary texts such as letters, newspaper articles, and public appeals. While the last part of the chapter briefly contemplates on the 1999 Cherokee Constitution, particularly to demonstrate how the written constitution allows a space for the reconfiguration of sovereignty, the chapter's main thrust lies in exploring the nineteenth century context.

The third chapter concentrates on Nepal's seven-decade experimentation with the written constitution. While the chapter discusses a range of metaconstitutional interests and effects such as how the genre was originally introduced by a threatened autocratic family regime to legitimize itself against the popular uprising in 1948, and also how the genre was also viewed as a claim of national sovereignty in the chaotic South Asian context of the 1950s and 60s, the major argument rests on the question of constitutional authorship. I argue that constitutional authorship - the question of who gets to write the national constitution legitimately — was the defining factor of political disruptions in Nepal from 1948 to 2015. Revolutionaries-a common denominator for a range of political parties and actors in a long history — from as early as 1948 internalized the idea from the international genre convention that a national constitution should be written by a popularly elected constituent assembly. While for a brief period in 1951 the king also seemed to agree with the revolutionaries, he took the constitutional authorship as his traditional prerogative - a symbolic exercise of his sovereign power, not open for compromise. The clash of these two visions of constitutional authorship and the nature of sovereignties and political 
philosophies suggested by these visions guided the seven constitutions written between 1948 and 2015. The chapter ends with a not-so-celebratory note: While the Constituent Assembly declared the new Constitution in 2015 ending the clash and abolishing the monarchy, the procedural nature of constitutional authorship with its roots in modernity could not fully satisfy the postmodernist interests of many Nepali constituents. Nepal experimented with a widely inclusive form of representation for the Constituent Assembly, but the strong opposition to the newly promulgated (and passed by an overwhelming majority of the Constituent Assembly) Constitution suggests that the respect for the constitutional authorship of popular majority itself is a matter of what Bawarshi calls "genre function." Given Nepal's constant introduction of new constitutions, the culture of organizing mass protests to demand political changes, and postmodernist identity politics together created a context that undermined the ethos of the constitutional authorship of popular majority. The debates on how the new Constitution could not respect the wishes of many communities demonstrated how the idea of national popular constitutional authorship was what Edmund Morgan has theorized a matter of "inventing people"-something discursively effected rather than a natural phenomenon unconditionally acceptable to all (13-14). However, since no equal functionally effective alternative genre exists to replace the constitution, it would be interesting to observe how the newly redefined sovereignty and national authorship would fare in the old country with the new Constitution. The fourth chapter brings the discussion of earlier chapters together and makes conclusions about the state of the written constitution as a genre in the early twenty-first century.

In the epilogue, "What does the Written Constitution as a Genre Teach Us about the Teaching of Writing?" I meditate on the pedagogical implication of this study. Genre theorists have widely commented on the significance of rhetorical genre studies to the teaching of writing 
and rhetoric (Bawarshi, Miller, Bazerman, Swale, Devitt). Genres constitute the teaching of writing, and any sustained discussion of a genre offers insights into at least the need of having to be aware of the structure, ideology and purpose of a genre. For the purpose of delimitation and precision in this section, I use the idea of threshold concept, pondering what the process of the writing of the constitution can reveal us about the nature of collaborative writing that we can use in the teaching of writing. Rhetoric and composition scholar Kathleen Blake Yancey argues that the threshold concepts of composition studies serve as the "articulation of shared beliefs providing multiple ways of helping us name what we know and how we can use what we know in the service of writing" (xix). As Yancey and the contributors in Linda Adler-Kassner and Elizabeth Wardle's edited collection, Naming What We Know: Threshold Concepts of Writing Studies, state threshold concepts are more about the articulations of ideas that we already know than about proposing anything completely new. Following their lead, I add a new threshold concept of writing as manifested by the transnational, transcultural contexts of constitution writing: a high-stake collaborative writing is complex and contested in nature - not always a friendly and smooth process as the adjective "collaborative" in the expression may connote. By "high stake collaborative writing," I am suggesting those public, professional and personal kinds of writing that would transform the lives of people writing the document. While constitutions, laws, and policy papers are some of the examples of high stake writing, many other academic and professional documents may also have high stake for collaborating writers. In a high-stake writing, collaborators bring in conflicting ideologies, identities and interests in the writing process, and they also perceive that the outcome of the writing project would significantly impact them, forcing them to maneuver the writing toward their interest and ideology, a condition that may compromise the logical progression of the writing process in the absence of a 
pre-writing agreement regarding how they would follow the process for the project's completion. In the transcultural, transnational and historically different contexts of constitution writing that I examined in this dissertation, conflict surrounded the writing process. For instance, in the United States in the 1780s, it was hard enough for the participants of the Philadelphia Constitutional Convention to come up with an agreed upon document, and the ratification process that followed the drafting of the Constitution was not less contentious. While the general Enlightenment philosophical platform provided the participants a system for exchanging ideas meaningfully in the convention, both the ideological and pragmatic differences among them made the Constitution writing process a heated business in the summer of 1787.

This threshold concept that collaborative writing is a complex and contested process requiring pre-writing agreement for the effective execution of a project builds on some of the other threshold concepts of writing studies. Victor Villanueva writes, "writing provides a representation of ideologies and identities" (57). Articulating another threshold concept of composition studies, Andrea A. Lunsford writes, "writing is informed by prior experiences" (54). Heidi Estrem states, "disciplinary and professional identities are constructed through writing" (55). Charles Bazerman and Howard Tinberg go even further and argue that, "writing is an expression of embodied cognition" (74). Placing these concepts together in the context of collaborative writing, it can be said that writers bring in different embodied cognitions, ideologies and identities. While the need of coexistence may have forced them to collaborate, often the collaboration of people with different interests and ideologies is charged with conflict. Such collaboration demands us to critically examine how the process of collaboration goes, who get to assert their agency in the process, how they negotiate what they are going to write, and how they manage their differences. Thinking collaboration by considering these factors has the 
capacity to transform the way we approach collaborative writing. In course of developing this concept, I also suggest how writing teachers can facilitate their students better by distinguishing labor-intensive and ideological collaborations. While the two categories are not completely separable in practice, having the categories and knowing differences between them positions teachers to approach collaboration with clarity and purpose, suggesting them to take appropriate pedagogical route. 


\section{Chapter 2: The Genre functions of the Written Constitution, Republicanism, and the Formation of the United States of America}

\subsection{Introduction}

As the introductory chapter established, the written constitution was a unique American invention that subsequently become a global genre ushering in a long era of nation-states built on the power of the written word. This power however was not a completely new idea for the delegates gathered in the Philadelphia Constitutional Convention in 1787: they had brought with them a dense history of experimentation with the form and procedures of drafting and adopting written constitutions. Before the promulgation of the 1789 Constitution, American states had written and rewritten constitutions, and in the process had established a political imagination that required a written constitution at the helm of a nation-state - not a hegemonic trait of the time. So, after the failure of the 1781 Articles of Confederations, the question was not about whether the United States needed a constitution, but about its fundamental nature - a thorny question that fired the debates and discussion to various directions during the framing and ratification of the Constitution. The debate highlighted that the genre had had its strong genesis and powerful currency within the political culture of the new republic, but it needed to address a host of complex and often contradictory pragmatic and philosophical demands of the new nation if the Constitution were to be the supreme law of the land - a high aspiration for the new genre that would both supplant the British tradition of unwritten constitution and place all other lawsincluding the state constitutions - within its jurisdiction.

Undoubtedly, writing about the U.S. constitution with a fresh perspective is a monumental task. Because of its centrality in American life, scholars from a variety of disciplinary and intellectual perspectives have widely commented on the Constitution. Every 
word in the Constitution and the motivations and histories behind the word are researched, debated and discussed to fulfil multitude of aims from finding a historical fact to forwarding an interest. ${ }^{18}$ Scholars also have studied the sources of thought for the Constitution and the very ideas of constitutionalism as it pertained to the framers. What has not been much discussed is how the constitution as a genre functioned in the context of late eighteenth-century America. This chapter is an attempt to answer that question.

In this chapter, I approach the Constitution from rhetorical genre perspective and ask what functions the written constitution performed for the framers. Indeed, as it does not need much argumentation now, the Constitution - as any constitution is expected to do so by nowestablished the framework of governance for the new nation. But that function alone, which appears to be a normal phenomenon for a twenty-first century reader steeped in the world of nation-states with written constitutions, represented an epochal achievement at the point when the genesis of the genre was gaining ground. What this chapter argues is that the Constitution helped the founding generation to contextualize republicanism to the United States by affording them a method to articulate a new governing system. The framers devised a government in such a way that constitutionalism would be the unalterable feature, forcing every generation of Americans either to be governed by the existing constitutional text or to amend it as per their aspirations. This promise came with the stipulation that the future generation would not be able to replace the Constitution itself. This focus on the codification of governing principles in the written form transformed the nature of politics. Now with the written constitution as the required governing code at the zenith of a nation-states, citizens could tally their civic behaviors with the externalized codes written in the Constitution. With this experimentation, republicanism entered

\footnotetext{
${ }^{18}$ See Akhil Amar for the textual interpretation of the Constitution, particularly for the meaning
} and motivations of the words in the document for the framers. 
into a new phase of history: during the Revolutionary War, classical republicanism was primarily a subjective phenomenon; the followers of republicanism during that phase introspected within to judge their behavior whether they had observed the virtuous conduct of republicanism as found in the character such as Cato. But with the written constitution as the definer of American republicanism, the followers of this lofty historical quest could see outside and evaluate whether they were conducting themselves with virtuously. To recapitulate the same point, I argue that the main genre function of the written constitution for the United States in 1780s was to formulate, contextualize, and externalize the idea of republicanism. The written externalized the idea of republicanism but without restricting the possibility of its redefinition. The Constitution would remain immortal freeing the people from the possibility of any whimsical human rule, but the people themselves would have the power to amend. This idea — the immortality of constitutionalism but the possibility of endless rethinking the best from of governance—in the Constitution opened a space for public rhetoric: the citizen would be exchanging persuasive ideas to change the Constitution so that they could have a "more perfect Union."

To make this argument, I refer to interdisciplinary scholarship from history to literature to legal studies. Approaching this way, my objective is not to create a thorough narrative of the entire process of the transformation of republicanism as manifested in more than one dozen constitutions drafted between the dates of the Independence and the inauguration of George Washington as the first president. What I'm doing is a symptomatic reading of the texts and context to suggest how the written constitution was the major player of the transformation of republicanism and the formation of the United States. With this argument, as it would be manifest in the later part of the chapter, I invite early American scholarship of that period to shift the focus from the written/spoken words to genres to understand a more definite role of the 
words in the inception of the United States.

In what follows, the chapter has four sections. The first section recounts the place of republicanism in early American scholarship, how republicanism' hermeneutical plasticity made it a formidable force in the Revolutionary War, and how the same interpretive elasticity opened it to be used in justifying many interests creating discordances in the newly independent nation. In this section, I propose, define and plain the notion of subjective republicanism to argue that the written constitution helped to transform the republican elasticity into a more definite governing structure. The next section highlights the debt of classical republicanism to the written constitution: not only the written constitution helped the United States to contextualize republicanism for it, classical republicanism's advocacy against a person's arbitrary rule provided the written constitution its main ideology — constitutionalism. The last section discusses the significance of this argument for early American scholarship particularly by highlighting how genre — not the word — should be the focus of scholarship that aims at excavating the formative influences of signs and symbols for the inception of the United States. Arguing that public sphere, written and spoken words, and eloquence were more the part of the activity system of the genre of written constitution than the definite shapers of the new governing system, the section insists on the need to foreground the role of the written constitution as a genre- not merely as a bundle of a printed words - in the formation of the United States.

\subsection{Subjective Republicanism, the Written Constitution, and the Externalization of Virtue}

Scholars have established that republicanism was the dominant political philosophy that inspired and guided the aspirations and conducts of the founding generation of the United 
States. ${ }^{19}$ Based on his archival research, primarily the personal letters exchanged among colonists during the mid-eighteenth-century, historian Bernard Bailyn has found the antiauthoritarian strand embedded in British Whig philosophy had prompted the colonists to interpret the British presence in America as an assault on their liberty(22-54). Gordon Wood thinks that the American revolutionaries borrowed the classical model of virtue, which led them to think of "a republic of equal, active independent citizens [where] . . the loss of independence and virtue was corruption" (104). J.G. A. Pocock thinks of the Revolution as a reenactment of a Machiavellian moment whose intellectual roots can be traced to Florentine Renaissance culture, where people realized that they can build the ultimate temporal society based on universal, republican values (-506-10). Robert E. Shalhope has termed the understanding formed around these historians as "a Republican Synthesis" pronouncing it as the formative intellectual and cultural force of the Revolutionary and early national period (49). In this synthesis, republicanism — with its roots in classical Roman tradition — entered the American colonies primarily through Scottish Enlightenment tradition and dominated the contemporary American imagination with a few key words such as liberty, virtue, and corruption.

It is also firmly established that Americans did not just adopt republicanism from European traditions but mostly adapted it to make it contextually relevant to the new nation. Constitutional scholar Dan T. Coenen argues that Hamilton and Madison "stamped the notion of republicanism with a distinctively American meaning" (93). He highlights three distinctions of the American contextualization of republicanism: "(1) the ultimate sovereignty of people, (2) the republican nature of all branches of government, and (3) the idea of distancing operations of their

\footnotetext{
${ }^{19}$ Joyce Appleby thinks that John Locke's liberalism was an equally powerful social thought in colonial America, particularly in intensifying the colonists' dissatisfaction with the British rule that added fuel to the Revolution.
} 
government from future control of the Constitution itself” (93). M.N. S. Sellers-with the advantage of his studies in classics, history, and legal studies_-argues, "Americans used their European predecessors selectively to advance a different, less democratic and distinctly American ideology" (xi). James Madison's notes from the Constitutional Convention, private letters among founding fathers, and the texts of debates surrounding the states and federal constitution in the 1780s represent the fact that the adaption was a deeply deliberate and arduous process. The sheer number of words exchanged during the process represent an enterprising American mind intent on solving a problem, particularly not repeating the mistakes of Roman and English republican experimentation. As the events in the first decade following the Independence - particularly the failure of the Articles of Confederation-suggested, the adaption was challenging and difficult; it involved complex processes and structures to create a collective view on governance.

I'm arguing that the most innovative and consequential of this process was the invention of the written constitution. The process involved all those experimentations with the genre carried out at state and federal levels, including the first major amendments of the Constitution codified as the Bill of Rights. The experimentations with the form provided Americans a conduit to think about a government plan that could uphold the basic attitude and motivation associated to republicanism. This process that culminated in the drafting of the Constitution defined republicanism for the United States. Willi Paul Adam has studied the history of the state constitutions drafted between the Declaration of Independence and prior to $1787 .{ }^{20}$ His study suggests that the states practiced diverse ways of drafting and promulgating constitutions. For them, no single form of republican constitution-making procedure existed as a reference. Some

${ }^{20}$ See Adams (pp. 61-114) 
of the drafters could discuss classical practices, but they were more abstract conjectures than the guiding principles of a genre convention. In most states, existing provincial congresses drafted new constitutions without recognizing the distinction between their traditional legislating functions and the new work of drafting and approving a constitution. The states of Connecticut and Rhode Island continued their colonial charters with a slight modification to note the Independence. Massachusetts' 1779 experiment primarily installed the ideas of constitutional convention and ratification. In the state's second attempt to write the constitution after the independence, Massachusetts organized the constitutional convention solely for the purpose of drafting its constitution, and the convention later presented the newly drafted constitution to the people for ratification - the procedure that served as a model for the Union. This history suggests that while republicanism was a widely respected and internalized political ideology of the time, it was through experimentations with constitutions at state and federal levels that an agreeable republican form of governance could be articulated. The written constitution as a genre thus provided a forum or a platform or a way to systematize the idea of republicanism in the way it could meet the expectation of the majority of the people in the United States at that time.

Explaining this thesis demands a theorization of subjective republicanism. By attributing the adjective "subjective," I'm trying to highlight two principal traits of republicanism in the way it was understood and practiced during the Revolutionary and pre-Constitutional phase of the new republic. First, it focused heavily on a person's virtue, placing the whole burden and responsibility of preserving oneself from the corrupting influence of power on the individual. From this perspective, republicanism was the political morality that individuals were free to exercise and would be honored for doing it in the best way possible for them. It became an individual ideal, following which could and would garner respect for a person from their society, 
but this political/social morality did not have any external authority to impose the republican virtue onto the individual. Indeed, in this vein of thinking, the external supervision of someone's conduct for assessing the republican conduct stood against the very core of the republicanism.

From this perspective, republicanism remained a quasi-spiritual political philosophy that individuals could use to preserve their liberty and to serve their life for the betterment of humanity. Central to this tenet is the idea of sovereignty. ${ }^{21}$ Subjective republicanism emphasized the idea that an individual is naturally sovereign to exercise his or her innate liberty. Thus, the subjective version of republicanism also placed significance on the individual's personal responsibility and virtue to safeguard one's sovereignty. In a sense, republicanism in this version was a religion without any punishing god overseeing a believer's conduct. Sovereign within, a propertied and self-sufficient human being would make the best call and judgment for herself. Stating another way, this version places the whole burden or responsibility of upholding one's virtue - whatever way it is defined — on the subject herself. Introspection, austerity, and sacrifice define republicanism in this version.

So, instead of looking for any legal systems outside, the followers of the subjective republicanism received inspiration from historical or legendary figures idolized for their republican virtue. Roman Republican figures such as Cato and Cincinnatus flared American imagination. Joseph Addison's 1713 tragedy Cato, for instance, was one of the most staged dramas in America in the second half of the eighteenth-century - a fact that demonstrates how predominant the republican legendary idols were during that time. That the play was so popular also suggests that subjective republicanism was not merely a philosophy of handful of elites; it

${ }^{21}$ See the introductory chapter for an account of how traditional sovereignty of the king bifurcated in the new republic and the citizen. 
formed a strong presence in the popular culture. ${ }^{22}$ Even in May 1778, General George

Washington authorized to stage the play in his military camp in Valley Forge, Pennsylvania. The staging neglected the Congressional ban on such kind of theatrical production. Historican

Bernard Bailyn notes the popularity and impact of Cato the character this way: "So popular and influential had Cato's Letters become in the colonies..., it gave rise to what might be called a "Catonic" image, central to the political theory of the time, in which the career of the halfmythological Roman and the words of the two London journalists merged indistinguishably" (44). ${ }^{23}$ It is well-documented that figures such as Benjamin Franklin, John Adams, and Patrick Henry adored the figure of Cato as the role model for stoic personal sacrifice, honorable public life and an example of republican virtue. Washington's letters were peppered with the quotes from the play. Within his lifetime, Washington was often compared to Cincinnatus. ${ }^{24}$

With the desire to have a clarity of thought, some scholars have tried to define the republicanism as practiced during the Revolutionary and early national period as something definite, something that would undercut my understanding of subjective republicanism. For instance, Sellers emphasizes how Americans "differed less about the nature of republicanism than the means of preserving it" (6). Sating that American republicanism was influenced from the Roman tradition and that the founding generation was well-versed in Roman political philosophy and history, Sellers identifies the following eight characteristics of republicanism practiced during the time: "(1) pursuit of justice and the common good, through (2) the rule of

\footnotetext{
${ }^{22}$ See Dr. Rob Hardy's note in this link: http://www.mountvernon.org/digitalencyclopedia/article/cato/. Hardy includes the number of significant studies on Cato and its impact on the formation of the character of the major founding figures of the United States. 23 The two journalists were John Trenchard and Thomas Gordon who wrote the letters under the pseudonym of Cato. So, besides the play, magazines and newspapers circulated the image of Cato in eighteenth-century America.

${ }^{24}$ See Lantzer (33-52) for the impact of Cincinnatus on Washington.
} 
law, under (3) a mixed and balanced government, comprising (4) a sovereign people, (5) a deliberative senate and (6) an elected magistracy" (6). The other aspects included "the patrician vision of (7) orderly liberty and (8) public virtue it sought to preserve" (Sellers 6). Undoubted, the existence of these features of republicanism at that time cannot be denied.

In forwarding the notion of subjective republicanism, I'm not arguing that these characteristics of republicanism did not prevail. Indeed, the framers of the Constitution and public of the time could identify and associate the characteristics enumerated above as republican traits. Mostly, these republican characteristics represented an attitude and ideal about what kind of political society Americans during the founding period wanted to have. What I'm arguing is that the republican attitude and ideal formed by these characteristics did not easily translate to a government plan that could address the challenges facing the United States. To assume that the commonly-held republicanism had the capacity to automatically translate to a governing form in that period has some implications: First, when we agree that the republicanism was the dominant thought of the Revolution, it should also be agreed that the Article of Confederation, which was the first constitution drafted immediately after the Revolution, must be said to hold the republican thought in its full intensity. This assertion can be made not because two temporary adjacent events always involve a cause-and-effect relationship, but because the Articles was thought to be the best expression of local sovereignty and individual liberty. If we agree with the proposition that the Article embodied the best form of republicanism because it embodied the Revolutionary spirit, the understanding implies that republicanism could not address the contemporary American need-particularly in the context of the failure of the Articles. Republicanism was just a quasi-spiritual political flare that could ignite the fire for the Revolution but did not have dimension of relevance for the post-Independence governance and 
nation-building. Thinking that way also implies that the 1789 Constitution is somewhat diminished in its observation of republicanism because of its difference from the Articles. Thus, instead of agreeing with any these important propositions and their implications, the more accurate way of understanding early national American republicanism would be to see it as a major but a flexible and quasi-spiritual political motif open to multiple interpretations.

With this line of reasoning, I'm not trying to argue that the Constitution does not bear the mark of republicanism. Nor I'm suggesting that republicanism was any less a powerful influencing thought. As Sellers argues, certainly, the influential figures of the founding generation had studied Roman history and the political thought associated with it in their school and college curricula, and the republicanism - along with other influences and historical, religious and personal inflections — served as the dominant ideology. The people immersed in this ideology could identify something that was against the basic tenets of this attitude and ideal. But republicanism - no matter how powerful it was - in itself did not have a ready-made governing program that could be installed in the new republic. Had it that kind of definite form, Americans did not need the complex transition of more than a decade before the ratification of the Constitution.

Indeed, this motivational aspect of subjective republicanism proved to be the most powerful potent force during the Revolution. The possibility of the plasticity of interpretation embedded within subjective republicanism could speak to a host of interests and aspirations, triggering a wide participation of colonists in the Revolutionary war. Mark Garrett Longaker has identified three versions of republicanism — millennial, manufacturing, and agrarian — prevalent in late eighteenth-century America: Rooted in puritan values that "advocate[d] community over self-interest," Timothy Dwight’s “millennial republicanism” aligned easily with a "federal 
theology" in the sense that the new nation would analogically serve as "a covenant between God and the American republic" (25). Alexander Hamilton's "manufacturing republicanism" advocated for strong federal government for safeguarding the Americans' liberty and sovereignty. Thomas Jefferson's "commercial agrarian republicanism" insisted on the independence of small state holders from the encroachment of a big federal government (Longaker 28-32). Longaker argues that the value of republicanism primarily rested in providing the founding generation a common set of vocabulary to articulate and exchange various positions in a language that they could share. But if somebody really tried to pin-point to a single, universally defined republicanism, none existed. As historical Mercy Otis Warren noted in her 1805 book, the way "interested and ambitious men [used], ... republicanism was an indefinite term. ... This was indeed, more the language of art than principle" (quoted in Sellers 3). Given republicanism's cultural capital, the people from different walks of life could use republicanism for their purpose in a positive way.

While the republicanism's plasticity helped mobilize large sections of Americans to participate in the Revolutionary War, the Cato-inspired subjective nature of liberty could not convert into a government structure needed for independent colonies. After the Independence, Americans did not agree easily on the kind of new government. Heated discussions and discordances prevailed. Ultimately, the republican antipathy towards a far-flung centralized government forced them to be settled with the 1781 Articles of Confederation that assigned practical power to the states, without positing any meaningful authority on the federal government. As it was revealed within a few years, the arrangement made in the Articles could not address the issues of national security and federal debt payment incurred during the Revolutionary war. The document — that would have a vaulted prestige today in par with the 
Declaration and the Constitution if it had worked — had failed. The failure made the founding figures realize that they needed to write a new constitution that could uphold the spirit of the Revolution as well as address the pragmatic concern of the new nation. The realization lead to the framing of the Constitution in 1787. But the rancorous debate on the Constitution during the ratification process fought in the public sphere often using the pseudonyms also suggested that republicanism could be brought to forward arguments in both sides of the proposed Constitution.

James Madison made a passionate remark regarding the limitations of subjective republicanism for the new republic at the Constitutional Convention on June $6^{\text {th }}, 1787$ :

In all cases where a majority are united by a common interest or passion, the rights of the minority are in danger. What motives are to restrain them? A prudent regard to the maxim that honesty is the best policy is found by experience to be as little regarded by bodies of men as by individuals. Respect for character is always diminished in proportion to the number among whom the blame or praise is to be divided. Conscience, the only remaining tie, is known to be inadequate in individuals: In large numbers little is to be expected from it. Besides, Religion itself may become a motive to persecution \& oppression. These observations are verified by the Histories of every Country antient \& modern. ${ }^{25}$

At the surface, this remark may sound only as a comment on the form of a government. But when examined closely, especially by thinking about the early American context suffused with the language of subjective republicanism, the statement implies how the new republic could not

${ }^{25}$ From James Madison Speech at the Philadelphia Convention, 6 June 1787; The Papers of James Madison Digital Edition, J. C. A. Stagg, editor. Charlottesville: University of Virginia Press, Rotunda, 2010. Original source: Congressional Series, Volume 10 (27 May 1787-3 March 1788). 
be formed solely based on the assurance that the common people would act virtuously. Madison thinks that while a few giants like George Washington could embody the Cato-like character in ethically challenging situations, it would not be practical to ask most of the people the same virtuous behavior without any external system of accountability. Thus, building a new republic on the assumption that people will behave honorably by themselves would be a pragmaticallycompromising idealistic proposition.

In the remark, he also highlights that it is not just a few people, but an elected majority could lose the "character." Influenced by an interest instead of the character, a majoritarian mobocracy — manufactured by a democratic electoral process — could jeopardize the rights of an individual. For Madison's audience at the convention, the claim did not need any example. The very need of the new Constitution arose from the fact that the states had failed to honor their pledge voluntarily. According to the Articles of Confederation, the Congress did not have the power to levy taxes on the people; the states that generated revenue through taxation did not contribute to the federal government to pay for the credits incurred during the Revolutionary War. Madison's audience had known this fact and had carefully studied many historical examples of how virtuous individuals had become victims of powerful majority. Thus, the genteel founding republican heroes gathered in Philadelphia for drafting the Constitution were not fans of democracy - especially in the way they understood the term. A thoughtful sovereign individual like Cato mattered significantly for them and saving the possibility of the existence of such individual with full integrity in the new Constitution remained their high priority for the health of the new republic. A majoritarian government and dependence on the people's virtue alone would not ensure such protection.

This kind of understanding was not an aberration in the long sweltering summer of the 
1787 Philadelphia. That the voluntary virtuous behavior - the cornerstone of the classical republicanism — could not serve the new nation was a widely shared view. Reporting the results of the Convention to Thomas Jefferson, who as the U.S. minister for France was taking his residence in Paris, James Madison notes,

A voluntary observance of the federal law by all members [states], could never be hoped for. A compulsive one could never be reduced to practice.... Hence was embraced the alternative of a Government which instead of operating on the States, should operate without their intervention on the individuals composing them; and hence the change in the principle and proportion of representation. ${ }^{26}$

By the time of the Convention, the delegates had understood that the virtue-based subjective republicanism could not pragmatically deliver to the people a political environment to exercise their liberty freely. For the framers of the Constitution, restraining the power of the majority and respecting the individual liberty become fundamental objectives in "the new plan of government." 27 The new Constitution thus needed a system of check-and-balances where the party or the person in power would not be able to violate the individual rights. ${ }^{28}$ For that purpose, the delegates envisioned an independent and stable judiciary with the power to interpret the

${ }^{26}$ The Documentary History of the Ratification of the Constitution Digital Edition, ed. John P. Kaminski, Gaspare J. Saladino, Richard Leffler, Charles H. Schoenleber and Margaret A. Hogan. Charlottesville: University of Virginia Press, 2009. Original source: Commentaries on the Constitution, Volume XIII: Commentaries on the Constitution, No. 1)

${ }^{27}$ The framers were thinking more about the new plan of government rather than the genre of the written constitution. In the contemporary writings, the two expressions are almost interchangeable, but "the new plan" is used more extensively.

${ }^{28}$ Certainly, the notion of individual did not include many human beings residing in the United States at that time. Enslaved persons were treated as property of proper individuals. Although many people found it abominable, the idea of an individuals' property rights sanctioned slavery. That only propertied white man could exercise his sovereignty without self-interest a powerful concept for the founding generation. 
Constitution. This same interest led to voluntary term limits for the Supreme Court Justices so that they could function without the any apprehension of firing from the elected governmental authorities. The point is this: while virtue-based and liberty-granting aspiration embedded in subjective republicanism could rally wide participation during the Revolutionary War, it was insufficient to offer an effective governmental framework in the post-Independence America. Only systematically delineated government plan could save the country and help the republic to sustain its republican aspiration. The written constitution become the tool to achieve that goal.

The written constitution however did not just translate classical republicanism into American context. The weight of the pragmatics was so heavy that the genre had to reconfigure republicanism in the image that would fulfill multiple interests in the prevailing context. With the progression of the 1780 s, the founders had started to feel that the Article had failed to address the need of the new nation. The 1781 Articles represented the republican spirt as it emphasized the sovereignty of states. As scholars have widely written, direct participatory local systems were the best forms of republic in the classical republican system; although the states were not as small as the classical republicanism suggested, their relatively smaller size in comparison to the Union made sense. But, as the events after the promulgation of the 1781 Articles suggested, the arrangement did not work. Now, the Congress needed to come up with an alternative plan if the United States were to remain viable. One challenge on the way remained re-contextualizing republicanism to meet the challenges facing the new republic. If the new nation were to sustain, republicanism - in whatever way it was understood - had to be adjusted with the pragmatics of the context. The new government plan had to preserve the motives and aspirations of republicanism that had inspired the Revolution. This was partly also because there was no other equally powerful alternative political philosophy that could be used to justify a new plan. So, 
adjusting the pragmatic concerns of the new republic and spirit of subjective republicanism was the prime objective of the new Constitution. To understand how different the discourse of republicanism had become and how far the pragmatics had taken lead during the drafting and ratification, we have to turn to Hamilton. In the article "Conjectures About the New Constitution," published sometimes between September 17-30, 1787, he writes:

The new constitution has in favor of its success these circumstances-a very great weight of influence of the persons who framed it, particularly in the universal popularity of General Washington - the good will of the commercial interest throughout the states which will give all its efforts to the establishment of a government capable of regulating, protecting and extending the commerce of the Union - the good will of the most men of property in the several states who wish a government of the union able to protect them against domestic violence and the depredations which the democratic spirit is apt to make on property; and who besides anxious for the respectability of the nation - the hopes of the Creditors of the United States that the general government possessing the means of doing it will pay the debt of the Union — a strong belief in the people of the insufficiency of the present confederation to preserve the Union and of the necessity of the Union to their safety and prosperity. (9)

While he justifies how the proposed Constitution would function in the best of the republican spirit in some of his federalist papers, this almost private conjecture demonstrates that the fate of the constitution rested on its ability to fulfil the commercial and military interest of the powerful elites. Undoubtedly, the Constitution gained favorable weight from the ethos of Washington and many other statemen, and it mattered that the people could trust Washington to lead the nation. 
But, as Hamilton conjectures, the republicanism of the new Constitution had a chance of ratification only if it could fulfill other, not-so-republican interest themselves. In other words, the spiritual virtue-based purity embedded in subjective republicanism was undergoing transformation through the Constitution. And, it had to go through that process if republicanism were to serve the new nation meaningfully. Thus, the written constitution transformed republicanism for Americans so that the political view could meet the interests of the time.

\subsection{Republicanism, Constitutionalism, and the Written Constitution}

While legal traditions had existed for thousands of years in many civilizations and certainly the United States was looking back to a long western tradition dating back to GrecoRoman time, the absence of written constitutions in the past raises the question: how did the U.S. Constitution or the state constitutions written during that period gain the kind of functional currency at a time when the genre convention was not developed enough to warrant such power? I argue that while the Constitution helped define republicanism for the United States, prevailing republicanism - no matter how subjective it was - also provided the context for the emergence of the genre. As Arthur E. Sutherland documents a long European history from the "Great Charter of $1215 "$ to many English experiments with Cromwellian Revolution and the 1688 Glorious Revolution prepared for the conceptual dawn of constitutionalism. ${ }^{29}$ Undeniably, these precedents of contracts and laws showed way to constitution. Maybe republicanism of some sort must have had some role in the case of those precedents for those charters, laws and contracts to be operational. But in the case of the United States in the eighteenth-century, republicanism played significant role in the advent of constitutionalism. Republican opposition to a person's arbitrary regime required a nation an objective set of rules for its functioning. If Americans did

${ }^{29}$ See Sutherland (1-10) 
not want a new British-modelled king, they needed a powerful governing tool with an ability to run the state, operate politics, and legitimize and delegitimize political activities. The written constitution answered that need. If no single person or divine authority were to be trusted with the ultimate power, a procedurally framed and ratified hallowed text could be agreed as the anchoring legitimizing force. Thus, it is this eighteenth-century American republican intellectual and cultural atmosphere that offered the written constitution the kind of genre power that it enjoys now. So, to recapitulate the argument, while Americans had a subjective and thus a multifaceted understanding of republicanism that hindered an easy and automatic emergence of a national government, the fact that republicanism was widely shared and valued provided an intellectual and ideological fertile ground for the genesis of the written constitution as a genre.

This point is important to accentuate because the analysis of the function of a genre needs an understanding of its ideology. As Amy Dewitt has argued, a genre embodies an ideological disposition. In the absence of an ideological or functional core, a genre becomes unrecognizable or stops performing in the way its convention dictates it to function. While exact functions of a genre can be different in various contexts, the genre imposes its ideology to a degree in all contexts and knowing the ideology can help a genre analyst to understand how a genre imposed its governing ideological disposition differently in different contexts.

The ideology of the written constitution is constitutionalism, the idea that written constitution holds the supreme position in a nation-state, that all political decision-including the amendments of the Constitution — should be made in reference to this text. The written constitution has been used for a variety of purposes for the last two centuries, and by now the genre has become so fundamental to the institution of the nation-state that even dictators deploy constitutions to legitimize their regimes even though they may not always observe 
constitutionalism to its core. This attraction to the written constitution comes from the genre's power of legitimization. But the question comes, since the legitimizing power of the written constitution does not emanate from constitutional texts themselves, what is the source? Certainly, for now, after more than two hundred years' history, the international genre convention that originated with the American experimentation accords the new constitutions their authority to legitimize and delegitimize activities within its jurisdiction. But in the eighteenth-century when such convention did not exist, republicanism provided the written constitution the functional power that other non-constitutional text cannot claim.

As Timothy Sweet has noted in his comments on the previous draft of this chapter, one fundamental characteristic marked the difference between Cato, the Roman republican legend discussed earlier, and the founding American generation. Cato chose suicide to uphold his republican virtue; for him, dying a worthy death triumphed over living a philosophically compromised life. While republicanism was still subjective in character, the republicanism that Cato crafted for him was a definite honorable code of conduct without much leeway for different courses of action: If one could not live virtuously, suicide remained one of the best alternatives. An honorable death sanctified a gloriously lived life. Indeed, dying untainted — that is, remaining uncorrupted until the end of one's life — held the most prized yardstick of traditional republicanism; remaining untainted needed the most challenging task-remaining sovereign over one's own disciplines. This yardstick tested one's ability to will the virtuous course of life, and to discipline oneself for remaining true to the will. So, while this kind of austere self-disciplinary republican mechanism provided some determined persons a spiritually guided secular course of life, republics failed constantly because republicanism rested mostly on personal ability to uphold the virtue. Ensuring the longevity of a republican political system thus remained 
secondary to living a virtuous life or dying a horrible death for this political imagination.

But American founding generation wanted a system of republican governance geared towards longevity rather than suicide. ${ }^{30}$ The generation constantly thought about the failure of the past republican experiments, taking the historical burden to themselves to correct the trajectories of republics. ${ }^{31}$ If they were to respond to this historical burden effectively, the founding generation had to be creative, going beyond merely adopting the Cato-styled republican belief. They had to devise a way to create a sustainable republic that would live long and pragmatically align the republican virtue with a multitude of multigenerational interests and fundamental human tendencies.

They responded to this historical burden by formulating the collective national selfhood through the written constitution. They created "we the people": Now, certainly it mattered that individual citizens conduct themselves in a virtuous manner, but even more important for the new republic became the preservation of the national selfhood by following constitutional procedure. What is interesting is that this national selfhood was more than the sum of the people; it was a constitutionally produced abstract idea that needed to be saved for the functioning and longevity of the republic. An individual citizen was theoretically a part of this

${ }^{30}$ Lincoln's Gettysburg Address is particularly remarkable in this connection. In the address, he highlights how the outcome of the Civil War was directly relevant to the historical burden expressed by the founding generation. Saving the Union for Lincoln was about whether the republican experiment could remain viable on the face of the planet. As Lincoln presents, the outcome of the Civil War would suggest whether the United States was a historically different kind of republic - one destined to last longer than to have vanished with the caprices of some players.

${ }^{31}$ That the new republic might not last longer was a constant theme during the formative phase of the United States. In the absence of an anchoring institution such as monarchy, the United States seemed an idealistic proposition liable to corruption. The continental size of the nation added further enigma. Given the fact that no public document like the Constitution in the way we understand it today existed prior to the American experimentation did not foreground the written constitution as the kind of anchoring institution in the way it emerged to be. It was a unique idea that the citizenship and public office would be based on an oath to uphold and protect a text. 
collective selfhood, could contribute to the construction of this selfhood by participating in the elections and other national ceremonies and events, and would automatically remain under the jurisdiction of this abstraction. But this collective national selfhood itself, however, was impersonal in nature. No single individual could assume or replace it. As explained in the introductory chapter, this collective national selfhood replaced the tradition monarch.

The construction of collective national selfhood - a concept that Lincoln was trying to preserve in the Civil War-was of paramount significance for the transformation of republicanism in the United States. Now, the people could be governed from outside, but the governing agency would not be the human arbitrary rule-like the one Americans experienced prior to the Revolutionary War. They would be governed by collective sovereign national being secularly crafted through their own participation. They could assume that this collective selfhood could be judicious, virtuous and republican in nature because they would themselves participate in its formulation. This formulation automatically incorporated the concept of the consent of the governed. While the agency was externalized in the Constitution with all the procedures and system of power delegation system codified by it, the people technically were governing themselves. The spirit remained truly republicanism.

Thus, while the written constitution helped the United States to contextualize republicanism, republicanism provided the written constitution the power to be the supreme governing agency of the land.

\subsection{The Constitution and Unresolved Ambiguities}

The claim that the Constitution defined republicanism for the United States does not mean that the document resolved all ambiguities and differences within republicanism. The text provided a workable framework so that an effective national government could be formed, 
sovereignties of the federal government and states could be settled for the time, and the division of power among the branches of the government could be determined. The Constitution also included specific provisions such as the term of office for the president, the number of members in the congress, and the process of constitutional amendment. But the power of the text originated from its flexibility of interpretation: The people ratified it because the document could bring-if not all—at least the differences between Hamilton and Madison together prompting them to advocate for its ratification. Not only the text included the provision of its amendment, the Constitution opened the door for judicial interpretation. It claimed its immortality and irreplaceability to the point that all future sovereignties and amendments would be dictated by the Constitution. ${ }^{32}$ But the promise of its immortality rests on the idea of an unending possibility of amendments. Indeed, the words in the preamble, "We The People of the United States, in Order to form a more perfect Union," which must have had a different meaning for the framers, captures the spirit of flexibility of the text. ${ }^{33}$

Indeed, the ratification could be materialized because the document could speak to the interests of the majority of the people. To garner that support, not only the framers inserted the unanimity of voice among them, but also carefully selected the words to avoid ideologically contentious dictions. Some ambiguity in the Constitution was part of the strategy. Literary scholar Richard Ferguson comments, "the unanimity injected into the language of the constitution. ... enforce[d] [internal] allegiance" and posed the unity to external powers (134). Only by the "epistemological ambiguities" and "philosophical uncertainties," and by the "careful

\footnotetext{
${ }^{32}$ The Constitution can be amended by adding new text but cannot be replaced by another text. Amendments function as additions on the existing texts. Even after the certain provisions are amended, the provisions continue to exist in the Constitution, although they stop functioning. ${ }^{33}$ The expression stood for the failure of the Articles of Confederation and hoped for the document to address the pressing concerns of the time.
} 
circumvention of controversial words like 'national,' 'republic, and 'federal," the drafters managed to pass the Constitution (Ferguson 130-137). Rhetorician Kenneth Burke in his $A$ Grammar of Motives characterizes the Constitution as "a set of [idealistic] wishes more or less at odds with one another" (375). Burke thus calls the Constitution "a calculus of motives" or an "anecdote summational in character...wherein human relations grandly converge" (Grammar $325,324)$. Repeating some of the ideas from the introductory chapter, Burke highlights the unavoidability of contradictory impulses in the Constitution for it to be acceptable for a large mass of people. To illustrate his point about the contradiction within the Constitution, he writes: “A public right, for instance, 'necessarily implies' a private obligation or a private jeopardy; a private right 'inevitably' implies a public obligation or a public jeopardy" (Burke, Grammar 375). Virginia Anderson characterizes the Constitution as a postmodern text, "a metonymic constellation of contingent possibilities relying on contextual interpretation for implementation and realization" (276). She further writes, "the Constitution is a bundle of incipient antitheses waiting to be highlighted rhetorically in litigation, then reconstructed rhetorically through paratactic reassociations (Anderson 276).

While these rhetoricians and postmodernists might see the contradictions in the Constitution as structures needed to craft a governing mandate and may attach a particular court verdict to a certain side of contradictions within the Constitution, the proponents of the idea of a living constitution find the document not performing that role. As the proponents of the idea of living constitution have argued, the functionality of the Constitution remains in its capacity to accommodate the changing historical perspectives. As they describe, the Constitution does not even have to be amended for such accommodation. David A. Strauss, a powerful voice for the living constitution, opines the value of the Constitution rests on proving "the common ground" 
for judicial interpretation (111). It does not mean that the Constitution does not have specificities. But on the contentious philosophical issues, the Constitution has an abundant "generality" that offers the possibility of attaching court decisions to the Constitution. He writes, "the genius of the U.S. Constitution is precisely that it is specific where specificity is valuable and general where generality is valuable" (112). Certainly, originalists reject this proposition and argue that the words of the Constitution as written during the Philadelphia Convention holds the capacity to direct judicial interpretation. They maintain that judges must refer to the intension of the framers of the Constitution and the amendments to make their decisions; doing otherwise would transform the judges into unelected legislators. While the originalists have a point and that the Constitution continues to shape American political and social life far deeper ways than many living constitutionalists may agree to, the fact that the nuances in the meaning of words change from one historical context to another suggests that clinging with the originalist interpretation may be a pragmatically unattainable hermeneutic wish.

So, all this discussion boils down to the following conclusion: While the written constitution helped the United States to define the terms of republicanism, it did not completely fix and settle the definition for always. The framers offered the frames of governance, for which details could be supplied later according to the spirit of the succeeding time. The Constitution provided a general framework on which every generation would have the opportunity to insert its idea of republicanism or an acceptable principle of governance by legislation, judicial interpretation, and constitutional amendments by following the procedures in the Constitution. This flexibility not only helped for the ratification, but also structured the possibility of the Constitution's growth — ensuring the longevity of the Constitution and the country in the process. In the absence of any traditional anchoring institution such as a monarchy, the Constitution thus 
became the core of the state that not only provided the United State a stable reference point but also the promise of growth.

\subsection{A Move from Written/Spoken Word to Genre}

Then the question becomes this: what is there to be gained by foregrounding the role of the written constitution as a genre in the externalization of republicanism and the formation of the United States? The role of the word in the formation of the Revolutionary culture and the republic is well-documented. Michael Warner's sophisticated book, for instance, has placed the written word at the foundation of the United States. Borrowing from Jürgen Habermas, Warner argues that print culture in mid-eighteenth-century United States created a public sphere that could comment on both the domestic and governmental spheres with an independence never seen so dominantly in the history before. All those intense deliberations during the ratification of the Constitution would not have materialized in the absence of the public sphere. He argues that the modern conception of citizenship that emerged during that period relied on the silent consumption of printed material, a process in which the reader could imagine as a member of what Benedict Anderson terms an "imagined community" built on the strength of print technology and the political and ideological apparatus that accompanied it. On the other hand, Sandra Gustafson and Christopher Looby in their separate works have highlighted the significance of the spoken word and eloquence for the large scale democratic participation of the time. ${ }^{34}$ Madison's documentation of the speeches delivered during the Constitutional Convention justifies Gustafson's argument that the direct oral exchanges of ideas was key to the negotiating process through which the framers could agree on a draft of the document to be sent for the ratification. While these scholars may disagree on the degree of significance in the mode of

${ }^{34}$ See Gustafson (140-99) and see Looby (3-10). 
delivery, they have collectedly established the primacy of the word in the creation of the United States. Indeed, this assertion cannot be denied; the United States is the republic built with the words.

But what I'm arguing is this: the words could be formative to the way the history of the United States unfurled subsequently because of the genre of the written constitution. Merely establishing the significance of the word or its deep and wide-ranging use does not explain how they formed the United States. In many ways these conditions prevailed in other European locations contemporaneously, a prevalence that did not automatically lead to the constructions of the nation-states. Indeed, the print culture brought about deep transformation in the political subjectivity of the people and the idea of modern citizenship became conceivable on this platform. But these factors, such as the existence of public sphere, the technological and economic infrastructure for the dissemination the printed word, and eloquence themselves served more as parts of what genre theorists David Russell terms as "activity system" for the written constitution. ${ }^{35}$ Russel argues that genres do not function independently; they need an entire system of activities for them to be functional. Unquestionably, these factors - print culture, public sphere, and eloquence — were not only parts of the activity system of the written constitution; they had their own impacts and must have been parts of other genre systems as well. And, indisputably, the written constitution as it developed in the United States could not be conceived without these factors. The written constitution could not have originated or got experimented or become functional in the absence of these factors such as the newspapers for printing federalist and anti-federalist polemics, coffeehouses for deliberating the consequences of proposed constitutions, and public addresses generating response from the common citizens.

${ }^{35}$ See the discussion of Activity Theory in the introductory chapter. 
These variables provided an indispensable supportive role for the wide-ranging experimentation of the written constitution at the state and federal levels. But their formative impact on the United States as a nation-state can only be explained by relating them with the genre of the written constitution. The nation could be conceived in a deliberate fashion because the genre provided a mechanism for such enterprise.

Thinking from the vantage point of Lincoln's Gettysburg address can clarify this point. The whole point of the Civil War as stated in the address was whether "a new nation, conceived in liberty, and dedicated to the proposition that all men are created equal...shall not perish from the earth." In the address, he uses the 1776 Declaration as the point of the new nation's origin. The United States might have gained independence and emerged as a new nation in 1776 and its Revolutionary ideals might have directed its future course, but the United States that he was trying save came from the Constitution. All conditions including the words, public sphere, and other documents such as the Declaration of Independence established the condition, but it was the written constitution that gave the government.

To state the same idea differently, the written constitution shaped the governing structure of the United States giving a concrete operational form to republicanism. Although the United States was conceived in the 1776 with republicanism serving as its governing ideology, both concepts remained oppositional semiabstract phenomena that could be highly effective in combating the British empire but proved short in details and functionality when having to address the governing needs after the Independence. Indeed, the Revolutionary ideals and republicanism offered the ideological foundation for the experimentation with the written constitution. But what is equally significant is that in the absence of this genre, some form of monarchy or a loose confederacy of not-so-fully-defined states or nation-states would have been 
the fate of the United States. The experiment that Lincoln was trying preserve originated from the written constitution.

To accentuate this point, we need some discussion of genre - particularly how genres create an environment for the possibility of an action. As rhetorical genre theorists have established, institutions, thoughts and social actions do not originate by themselves. ${ }^{36}$ While genres are not completely deterministic because the user uptakes of a genre can vary from one situation to another producing situation-specific result, how we act in certain situations are mostly shaped and made thinkable by the existence of a range of genres in our disposal. As Anis Bawarshi argues the availability of genre for a social action makes its existence possible; a typical recurring social action anticipates the existence of a corresponding genre. This idea implies that any theorization of the formation of the United States entails the recognition of the roles of genres. Words themselves do not make institutions; they need to be structured in genres for creating recognizable, recurring situations. Undoubtedly, the United States in eighteenthcentury did not ready-made genre convention except some motifs offered by classical republican references. The whole experimentation with the written constitution in the two decades following the Independence not only gave the world the genre in which a secular, republican nation-state could be imagined, but also served as the formative genre for the United States.

To highlight the genre-function of the written constitution, it would be important to discuss how the written constitution was different from the genres associated with it in the past. ${ }^{37}$ The Constitution embodied a remarkable departure mainly in two regards - its immortality and the ability for amendment. The Constitution played with an interesting structural puzzle: almost

\footnotetext{
${ }^{36}$ See the introductory chapter for an extensive discussion of how genres shape actions.

${ }^{37} \mathrm{I}$ 'm grateful to Dr. Timothy Sweet for pointing me to this direction, particularly asking me to think about the difference between the legal contracts and characters of the past and the written constitution.
} 
everything written in it can be changed, but the Constitution itself could not be replaced. ${ }^{38}$ The spirit of the time could modify the text but the constitution itself could not be discarded. This condition equips the constitution with a unique genre power; it places the idea of constitutionalism at the center of the new republics' policy. Now, the people-common citizens and people holding the public offices - were accountable to the Constitution. The allegiance to the Constitution — not the king — thus become the central tenet of this new political imagination. ${ }^{39}$ Indeed, the genres performing some functions of the written constitutions existed throughout human history. The functioning of an organized community needed governing laws; even despotic rulers who loved to present themselves as the rule required to issue decrees for governance. No matter how severe, brute power alone never organized human society. Often, such power was used to enforce the law people did not find conscionable. Within the European tradition, non-autocratic laws existed; the whole history of republicanism in a sense was about the practice and quest for such kind of law. For instance, the 1688 Glorious Revolution of Britain constitutionalized monarchy and established the supremacy of parliament. New laws were passed

${ }^{38}$ The functional efficiency of this conundrum could be understood with the example of the 1990 Nepali Constitution. Widely touted within Nepal and aboard, this constitution was a compromised document that ensured constitutional monarchy and parliamentary democracy. In one unique way, the constitution differed from the American Constitution. It not only claimed its immortality but also presented certain features of the constitution as inalterable. That provision of inalterability - while it worked perfectly within the power dynamics of time when the Constitution was framed - created resistance against it. Given the idea of certain things' inalterability, even the proponents of the constitution could not speak in the document's favor, requiring the country to write a new constitution. The longevity/immortality of a constitution requires a limitless transformability. It is in this structural conundrum rests the genius of the American Constitution.

${ }^{39}$ For a twenty-first century American, who grew up reciting "the Pledge of Allegiance" in her school, this notion may appear to be a simple, everyday phenomenon. But it is in this capacity to be so common and applicable in everyday life lied the unique historical innovation involved in the emergence and function of the written constitution. Previously, allegiances used to be either to the god, a king, or to organizations - not to a text. The puritan foregrounding of the Bible as the text must have had its influence in this development, but again such sources should not undermine the innovation and formation of the genre itself. 
for that effect. But what is unique with the American Constitution was the idea of amendment. The Constitution did not have to die for the new ideas to be incorporated: This promise of constitutional immortality and ever-lasting growth established the idea that a country could be anchored around the text while the text itself could go through modification.

\subsection{Conclusion}

Thus, the written constitution externalized subjective republicanism in such a way that republicanism could be continuously redefined through constitutional amendment. The Constitution promised the people the inalterability of constitutionalism that there would be no human dictator lording over them. The genre also promised that the people could forge their rules collectively by codifying them in the Constitution. The written constitution thus served as the major tool for the United States to transform the subjective form of republicanism into a governing political structure, a structure that provides a solid anchoring framework for the governmental operation but also is flexible enough to incorporate changing historical perspectives. The printed words, public sphere and eloquence were necessary conditions for the emergence of the genre of the written constitution; they therefore functioned as parts of infrastructure for the written constitution but were not in themselves sufficient to define republicanism as a governing form and to formulate the United States as the kind of nation-state as it came to be. The written constitution assumed the pivotal challenge of contextualizing an ancient subjective political ideology into a governing thought — a process that also inaugurated a new kind of secular politics of nation-states in the world.

Although this chapter has established the leading role of the written constitution in formulating republicanism to the United States, the project would benefit further from a research on how the experimentations with individual state constitutions in the early national period led to 
the possibilities for the federal Constitution. That the art and genre of the written constitution emerged from the rich and extensive experimentation with state constitutions is well-documented fact in scholarship. But a nuanced research on how republicanism articulated in the Constitution itself was slowly fine-tuned with different state constitutions and what aspects of which constitutions became formative structures for the federal experimentation would add details and insights in my argument. 


\section{Chapter 3: The Cherokee Constitutional Rhetoric: From Eighteenth-Century Politics of Identification to Twenty-first Century Vision of Transterritorial Sovereignty}

\subsection{Introduction}

In 1827, the Cherokee Nation promulgated its first written constitution, creating a western-styled centralized government that undermined its traditional system of independent towns. ${ }^{40}$ Faced with the crisis of removal from their ancestral homeland and prospect of annihilation, the Cherokees at that time needed a one-door political authority to negotiate with the United States in their attempt to save their land. Amidst their relatively dwindling fighting power compared to the growing U.S. military strength, their only meaningful recourse for protecting their land was to use the discourse that the United States could understand. In a sense, the Cherokees entered that phase of history when they had to fight for their survival and sovereignty rhetorically — persuading the United States on the value of their continued existence in their land instead of winning the enemy by warfare. This need and ability to respond to the shifting national and international context has remained a potent instrument of resistance, survival and sovereignty for the Cherokee Nation historically from its first adoption of the written constitution in 1827 to this day, making the Nation a rich field of rhetorical actions.

As the introductory chapter describes, the major thrust of this dissertation rests on understanding the genre functions of the written constitution. Keeping that interest in mind, the question for this chapter becomes, what function does the written constitution perform for the Cherokee Nation? Focusing primarily on the two phases of the Cherokee history - the first third of the nineteenth-century and the last quarter of the twentieth-century because of the Nation's

\footnotetext{
${ }^{40}$ See Boulware for how the Cherokees maintained independent upper and lower towns before the emergence of the Cherokee Nation. See Conley (75-80) for Cherokee matrilineal clan system: every Cherokee belonged to one of the seven clans, but the clans themselves did not make a political unit because one could find people from different clans in a town.
} 
intensified constitutional activities during the periods - I demonstrate that the written constitution as the most powerful legitimizing political genre of the secular west provided the Cherokee Nation with a dominant space for articulating its sovereignty. Amidst the imminent removal from their ancestral homeland in the early nineteenth-century, the Cherokee elites realized that they could make a compelling case in their favor only by identifying with the discourses, genre conventions and institutions of western modernity if they were to survive the massive imbalance of power between themselves and the United States. They launched a rhetorically powerful program that I—drawing on Kenneth Burke—call 'the politics of identification' for which they transformed themselves into a modern nation-state, used their transformation as the proof of their progress in the way demanded by the Washington Administration's Indian policy, and appealed to a range of the entities of the United State from public sphere to the Supreme Court to recognize its sovereignty and independence. The 1827 written constitution, where they asserted their sovereign ownership to their ancestral land as specified by the treaties with the United States, remained at the core of this entire process. This claim that the nineteenth-century Cherokee adoption of the written constitution and discourse of civilization was a part of politics of identification designed for national sovereignty directs the scholarly conversation beyond assimilationist-traditionalist paradigm.

While the 1976 and 1999 Cherokee Constitutions still accentuate the idea of the written constitution as a major legitimate space for articulating national sovereignty and its internal distribution, the documents also demonstrate that sovereignty is not an ahistorical phenomenon. Practices of sovereignty are historical formations produced with the use of genres in rhetorically active situations. For instance, while the 1976 Constitution does not include strong statements on the Nation's sovereignty, the mere fact it was issued after a long history of powerlessness 
displayed the idea of the Cherokee Nation as a distinct and separate identity. The 1976 Cherokee Constitution's mandatory provision of its revision by every generation opened the space for the 1999 Constitution that dramatically redefines the contours of a nation's internal sovereignty:

Faced with the limited land-base and the need to address the representation of dispersed population outside its territorial boundaries, the 1999 Constitution envisions what I call a "digitalized deterritorial sovereignty." In this vision, the citizens of the nation residing outside its formal territory can send their representatives to the National Council without having to register with any of its territorial districts. To use the possibility of synchronous presence afforded by the digital media, the constitution requires the government to maintain a continuous system of publication and contact with its citizens. While other old systems remain functional, the Nation maintains the required connection now via its official website, catapulting the vision of a nation beyond territoriality to the digital deeper space. I argue that the further articulation of this vision can serve as an example to other nations with deep ramifications to how we think of the nation-state and its relationship with territory.

While the visions of sovereignty in the 1827, 1976 and 1999 Cherokee Constitutions may be different, what grants them the position of legitimacy is the function of the written constitution. Legitimizing function of the written constitution has become such a hegemonic ideology by now that stating it seems almost like a redundant, all-known, unnecessary fact. But it is by stating the all-known, too obvious to be told, that we come to realize the constructiveeven deterministic - ideology of a genre. The written constitution as a genre might have remained fundamentally similar (not identical) in its form in its existence for more-than-twocenturies, but its power does not lie always in shaping the exact nature of the nation-state or 
sovereignty — but in providing a space for articulating them. The deployment of the genre in the Cherokee Nation's history testifies this fact.

What follows is divided in main two parts. In the first part that covers early nineteenthcentury context, I read the 1827 Constitution, laws, lawsuits, court verdicts, memorials, editorials, and other primary documents to demonstrate the logic, nature and effects of the Cherokee politics of identification. My aim in establishing the broader context of the politics of identification - instead of merely dwelling on the 1827 Constitution alone - is an attempt to manifest how the function of a genre such as the written constitution can be understood only by placing it in the entire system of activities in which it participates. Besides rhetorical genre theories discussed in the introductory chapter, I also use rhetorical concepts from Kenneth Burke and Homi K. Bhabha, cultural theories of digital technology, and various theories of sovereignty in course of my interpretation. In the first part, I hope to demonstrate that the Cherokee Nation appropriated the discourse of modernity — the written constitution and the institutions and political procedures instituted by such constitution - to establish the identification effect with the United States, and, in the process, exposed the ambivalence of U.S. colonial discourse that exerts its force even today with new intensity_ often in the language of formal apologies. In the relatively shorter second part, I focus on the 1976 and 1999 Cherokee Constitution to particularly highlight the innovation in the conception of sovereignty and how the written constitution has served as the generic locus of such innovation.

\subsection{The Rhetoric of Survival: Nineteenth-century Cherokee Adoption of Modernity, the Politics of Identification and the Written Constitution}

In the early nineteenth-century, the Cherokees found themselves in such an existentially threatening situation that their traditional structure of internal politics and method of conducting 
foreign relationship could no longer sustain them in new international political order. In the context of the disappearance of many other Native American tribes and the mainstream United States' prognosis that the Cherokees also would follow the suit, the Cherokees needed a survival strategy. Since they could not fight a traditional war with neighboring states or the federal government, the Cherokee elites realized that they could survive only by appropriating the master discourse of Euro-American modernity. They transformed themselves into the image of the United States by constituting a centralized national government, of which the declaration of the 1827 written constitution that was modeled after the U.S. Constitution was a pivotal moment. In a powerful rhetorical study of the 1830 Indian Removal Act and the two memorials submitted to the Congress by the Cherokee Nation and its citizens against the removal, Arnold Krupat analyzes the nature of Cherokee argument. He writes, "Cherokee removal, as emplotted by the Cherokees, is not the tragic story of the Whites would tell of the sad-but-just-punishment meted out by the God, fate, or even the progress of history" (161). It would instead be "the story of ironic victimization" (italic origina,161). The Cherokee emplottment "will not allow their dispossession to be seen, as savagist ideology would have it, as inevitable or necessary, neither God's will or Nature's law" (161). It would rather be "the result of no more than the force of American imperial power" (161). In the rest of this section, I hope to demonstrate that the Cherokee emplottment of the story as the "ironic victimization" rested on the rhetorical strategies of adopting and identifying with the discourses of the west so that they could establish themselves as the victims within the category comprehensible and recognizable to the United States.

This rhetorical move of combating the existential crisis by adopting the master discourses of the enemy can be best characterized as the politics of identification — using Kenneth Burke's 
well-known theory. Instead of opposing the basic character of the United States as the intruding inimical force into the Cherokee territory, the politics of identification allowed the Cherokees to appeal to the moral and legal foundations of the United States for their sovereignty. In adopting modernity, the Cherokees tried to transcend wartime strategies and confrontational politics "of scramble, of insult, bickering, [and] squabbling" (Burke, Rhetoric 20). ${ }^{41}$ They could instead "look beyond this order [that of traditional war], to the principle of identification" — a process through which they could forge a cooperative, communal and recognizing relationship with the United States by "mimicking” (in Bhabha's sense of the term) the western discursive and political patterns (Burke, Rhetoric 21). ${ }^{42}$ Speaking the same language could help them to establish a subliminal connection with the United States, a connection that they would use to assert their existence as a distinct political entity — a relationship of equal fraternity and understanding: "you persuade a man only in so far you can talk his language, tonality, order, image, attitude, idea, identifying your way with his" (Burke, Rhetoric 55). By transforming themselves into the discursive and institutional pattern of the United States, the Cherokees tried to strike a communicational cord that would require the parties in the conversation to recognize one another's basic existence, dignity and sovereignty.

${ }^{41}$ One major tendency among Burke scholar is to rhetoricize the idea itself, particularly by placing it in the historical, cultural and biographical contexts of its origin. M. Elizabeth Weiser thinks that the idea was the theorist's response the twentieth-Century World Wars and philosophical conundrums. Richard Graff and Wendy Winn think of identification as a cognate concept coevolved with Perelman and Olbrechts-Tyteca's notion of communion. They think that the identification and communion as rhetorical concepts serve as New Rhetoric's master terms with some resonance with Aristotelian enthymeme. On the other hand, John W. Kirk thinks that identification is not merely an extension on Aristotle's idea of persuasion, but "an essentially a new term" that "can no longer be profitably grouped within classical tradition" (414).

Jay Jordon (265-269) chronicles the evolution of Burke's understanding of identification.

Edward G. Berlinski argues that Burke borrowed the term from Freudian psychoanalysis and was a novel contribution to rhetoric because of its focus on unconscious intersubjective process of exchange based on the participant's identity (30-67).

42 See Bhabha's “of Mimicry and Man: The Ambivalence of Colonial Discourse." 
The attraction of this self-transformation in the image of the other for the Cherokees rested on the identification's promise of consubstantiality. On consubstantiality, Burke writes,

A is not identical with his colleague, B. But insofar as their interested are joined, A is identified with B. Or he may identify himself with B even when their interests are not joined, if he assumes that they are, or is persuaded to believe so. Here are ambiguities of substance. In being identified with B, A is "substantially one" with a person other than himself. Yet at the same time he remains unique, an individual locus of motives. Thus he is both joined and separate, at once a distinct substance and consubstantial with another. (Rhetoric 20-21)

In being identified as a modern nation-state with a written constitution, the Cherokees could claim that they were "substantially one" with the United States. However, this identification or unity with the western modernity was valuable for them only because the United States-the consubstantiated other - could recognize the Cherokees "at once a distinct substance and consubstantial with another." Therefore, here was an attempt by an existentially threatened tribe to establish a subliminal communal connection with its counterpart through the adoption of foreign discourses, institutions and culture. In the process, they created what Timothy Sweet calls a "counternarrative," not opposing the white discourse itself, but using it to argue how they had "improved" as per the attributes expected of "civilized" persons and culture from the standard of contemporary mainstream white discourse. ${ }^{43}$

43 As Sweet argues, the Cherokees formulated a counternarrative with the claim that "Indians themselves could participate in the movement of progress, or, in contemporary language, 'improvement"' (124-25). As he notes, the Cherokee counternarrative appropriated the white discourse of "improvement" that valued the image of "sedentary farmers," making pro-Removal whites difficult to argue "that Indian 'savages' were not making the best use of the environment and its capacities to ground 'Civilization"' (123). But, as Sweet demonstrates, the Cherokee 
Such appropriation of modernity — an attempt at identification with the warring partycould be a rhetorically influential politics for the Cherokee Nation because of the particular nature of the United States' Policy of Indian Civilization of that time. As the policy's name encapsulates, when the Washington administration, particularly Secretary of War Henry Knox, formulated the plan in the late 1700s, the administration's intention was Indian containment through the Cherokees' Christianization, participation in trade, and conversion from hunting to agriculture. Putting it another way, the policy planned for the construction of an amenable and recognizable Indian, someone who could be controlled "disciplinarily," if not assimilated fully. ${ }^{44}$ However, the Cherokee elites saw an opening in the policy for their own politics; they could appropriate the policy thoroughly directing it beyond the project's original purport. They could transform themselves in the image of "civilized Indians," but the transformation would be used to forward their own cause instead of fulfilling the policy's intended original intention. As Andrew Denison writes, “The creation of a new Indian government was hardly what Knox had in mind when he made Indian Civilization a goal of federal policy. For the Cherokees who led the fight against the removal, however, the tribe's written laws and political system were among the highest expressions of Cherokee progress" (20). Instead of assimilating themselves to the United States, Cherokees turned the U. S. policy into their own project. For them, the value of the project rested on the fact that it could be a "persuasive discourse as a discourse of cooperation through identification," where "the writer attempts to identify or define in the entire course of discourse...in relation to her audience" (Mao, "Persuasion" 137, 138). In this politics of

counternarrative was not designed for assimilation; the Cherokee spokesmen "insisted on separate nationhood and national sovereignty" (125).

${ }^{44}$ In the sense of Michel Foucault uses term in Discipline and Punish: The Birth of Prison. Disciplining for him is transforming habits using the discourses so that people start governing themselves according to norms. 
identification, the subjects appropriated the foreigners' project to the point of exceeding its original purpose. Using Homi K. Bhabha's term, the project was a politics of "mimicry" in which the Cherokees camouflaged themselves in the dominant discourse while not allowing it to totalize them within the parameters set by the policy. Through the project, they tried, as Burke describes, "producing assent by such appeals to character and emotion as [to] arouse the audience's confidence in the speaker and his cause" (quoted in Wible 272). In a sense, the Cherokees developed the United States' civilizing interest to an ironic level by claiming that they have become the whites themselves in terms of civilizational value. For instance, their appeal submitted to the U.S. Supreme Court against the state of Georgia in 1831 claimed, "They were willing to submit to a comparison [in terms of the progress they had achieved] with their white brethren around them" (Peters 27). The value of such claim of equivalence with the whites rested on the assumption that it would deprive the white establishment's justification of the Indian dispossession based on Native savagery. Theda Perdue writes, "The rapid acculturation of the southeastern Indians in the first three decades of the nineteenth century weakened old justifications for dispossessing 'savages,' so states whose chartered boundaries contained Indian land began to insist that tribal governments threatened their sovereignty" (Perdue 1980, xxi). Thus, by turning the U.S. policy of Indian Civilization into their sovereignty-protecting project, the Cherokees projected themselves as a "rational" nation-state instituted in the tradition of modernity and thus worthy of participation, dignity and rights in the international system.

Their politics of identification can be theorized as having three phases. In the first phase, they organized themselves into the Cherokee Nation in the image of the United States. In the second phase, they used their transformation as an evidence of their "improvement" to generate the United States' public opinion against the removal. In the third phase, they appealed to the 
U.S. court system to stop the White encroachment into their land when their public campaign could not garner enough support in the Congress against the Indian Removal Bill. The entire process was the politics of identification designed not for assimilation in the way anticipated by the contemporary federal Indian policy but a calculated move for claiming difference and independence by the tribe that had exhausted other instruments of effective resistance.

\subsection{The First Phase: The Cherokee Transformation and the Politics of Identification}

The first part of the Cherokee politics of identification involved the self-transformation in the image of the United States. As Cherokee historian Robert J. Conley writes, the "push toward remaking the Cherokee Nation in the image of the United States" turned the "the period between 1819 and 1827 [into]...the single most remarkable period in Cherokee History" (103). As he sums up, the major motive for this unprecedented, "concerted effort at culture change" emerged from "a powerful impulse to hold the line against any further incursions on the Cherokee land base" (103). This degree of exigency behind the transformation can be gauged by the fact that the Cherokees were trying to replace a civilization "that had developed over countless generations and was especially suited to the needs, beliefs, and circumstances of the Cherokees" and that had "provided a safer and more secure environment for women and children" (Conley 103-104). But the love for the traditional way of life weighed lesser in significance compared to the existential crisis brought about by the prospect of removal. The Cherokees therefore devoted to the change so deeply that "for any group of people to consciously remake themselves, to reshape their social and governmental institutions according to a set of foreign beliefs and forms, and to do so thoroughly, so well, and so quickly is remarkable occurrence in the history of the world" (Conley104).

Undoubtedly, this dramatic attempt for the swift modification of a whole culture did not 
emanate from the Cherokees' sheer love of western civilization. The incessant ceding of the land with an ever-new treaty with the Euromericans had forced them to reckon on their historical condition and to take an appropriate action if they were to survive at all. Almost all treaties signed earlier with the British government and later with the United States included a clause that the treaty would be the last one and the remaining land "shall forever" be protected for the tribe. However, the perpetual pressure for a new treaty and the federal government's 1802 promise to Georgia that it would help extinguish the Cherokee title to the state essentially cast the shadow of doom for the Cherokees. As John Ridge, an influential young Cherokee political leader wrote in the mid-1820s, "Their existence was in danger \& the Remedy was within themselves \& this could be affected in the amendment of their government" (37). It was not that the Cherokees did not have a government before, but "their chiefs were numerous and their responsibility was trifling. Lands then could be obtained of them at a price most convenient to the U. States" (Ridge 37). Ultimately, "the eyes of our Nation were opened to see their [the Cherokees'] folly" (Ridge 37). During this period, they formed a centralized government both to create an internal order as well as to find a single legitimate authority to negotiate treaties with the United States. They also introduced Euromerican constitutional and institutional apparatus designing themselves into a recognizable entity adapting the western legal tradition, an attempt at what Bhabha calls "mimicry" to ward off the danger by an existentially threatened people.

To understand the persuasive force in this argument for the adoption of modernity, we should turn to the Cherokee Nation's internal politics, particularly to the question of how the reformist section ultimately won over the forces that insisted on continuing with the traditional life style and political organization. As it can be expected in an old culture with engrained personal, political and civic patterns, there was formidable resistance to the adoption of western 
political structure and mode of living within the Cherokee Nation in the early nineteenth-century. Acculturation in the image of white civilization and the forging of Cherokee identity based on this "improvement" was not a smooth, automatic sail. Historian Theda Perdue writes, "In the 1820s a major controversy erupted between progressives, who wanted Cherokee society to mirror that of Anglo-Americans, and traditionalists who wanted to preserve aboriginal practices and beliefs" (159). The conflict become intense with "the proposal that the Cherokees write a republican constitution" (Perdue 159). With the promulgation of the 1827 Constitution, local communities would lose their traditional power as it would be delegated to elected officials and centralized government. As William G. McLoughlin recounts, the introduction of national laws and the adoption of a written constitution in the 1820s also instigated "a widespread popular uneasiness" particularly because of "persistent efforts by the acculturated elites to please the missionaries by denigrating the customs and pastimes of the majority" (366). Despite this opposition, the progressive wing - made up mostly of mixed blood citizens with the skills to navigate white cultural world relatively effectively — could garner enough support within the nation because it demonstrated that transforming the Cherokee identity into the image of white civilization was the best politics available for maintaining their existence and sovereignty during that historical juncture.

Major Ridge, one of the most influential Cherokee leaders of the time, exemplifies the spirit of the politics of this macro tribal transformation at the personal biographical level. He was fundamentally a traditionalist in his political and cultural beliefs in the first decade of the nineteenth-century; he fiercely opposed to any further ceding of the land, particularly as seen in the revolt of the young chiefs in 1808 of which he was a major voice. But his engagement in the tribe's politics as well as in wars - even in the ones that he fought along with Andrew Jackson in 
the late $1810 \mathrm{~s}$ - must have taught him that the Cherokees needed a dramatic transformation within themselves and their style of engagement with the whites if they were to survive the impending removal and the existential threats posed by it. By proposing John Ross, a young mixblood Cherokee in a culture that prized age and war experience in its leader, for the leadership in 1818, Major Ridge placed someone at the helm who could not only be the face of the changed Cherokee Nation but also could lead the politics of identification effectively. In a sense, his shift represented the win for the progressive wing within the internal politics of the Cherokee Nation.

Certainly, the progressive wing itself was not of a single unified view regarding the place of the United States in the Cherokee identity. As the post-1830 events would play out, Elias Boudinot, the founding editor of Cherokee Phoenix, for instance was at one end of the spectrum regarding the Cherokee Nation's relationship with the White world: he had 'genuine admiration for the United States as a model or culture and government," believed that "civilization grows from savagery to civility," and disdained "any definition of Native culture that might include traditional practices and beliefs" (Schneider 151). While he was against the removal originally, he signed the Treaty of Echota that allowed the United States to claim the legality of the removal and the Cherokees' willingness for the action. Principal Chief John Ross however was against the treaty as he differed from Boudinot in his assessment of how far the Cherokee Nation could save its sovereignty against the removal policy. Despite this difference, they did not differ in terms of the politics of identification. The progressive camp, mostly represented by mixed race Cherokees, could become dominant within the Cherokee power dynamics because they could demonstrate the logic of the politics of identification in the acculturation process.

Then the question becomes, was the "civilization" not a genuine interest of the Cherokees? The motivation in their rhetorical maneuvering of resistance becomes obvious if we 
analyze the whole situation by using the categories agent, agency, scene, purpose and attitude as presented in Burke's dramatistic pentad-particularly to remove the confusion between "agency" and "purpose." Was modernity the "purpose" for which they organized their loosely associated independent town governments into a bureaucratic nation-state, or an "agency" through which they tried to preserve their sovereignty by remaining in their contemporary homeland? First, as the state of Georgia and the United States started to pave the way for removing them, they refused to be a passive "scene" or ineffective waiter of the doom that engulfed most of the other Native American tribes. Rather they actively tried to be the "agent" of their fate through the "agency" of civilization and modernity. Thus, their embracing of the instruments, discourses and institutions of western modernity did not entail the purpose itself; It rather was an agency-a tool-for a different purpose. Although many Cherokees saw value in modernity and civilization themselves, the major impetus (as embodied in letters, memorials and legal briefs) behind the whole project of identification and self-transformation was a collective strategy for preserving their sovereignty, particularly the land base as specified by the 1785 treaty of Hopewell.

The 1827 Cherokee Constitution particularly presents the purpose of the adoption of modernity in two ways. First, as Lewis Cass observed then, the declaration of the Constitution itself made the statement that Cherokee embracing of the "civilization" was not designed for assimilation. The Cherokees wanted to be like the United States, but not a part of the United States itself. An epitome from the perspective of identification project, the Constitution was almost the replica of the Constitution of the United States: it introduced a republican form of government with check-and-balances among the three branches of government, and divided the nation into eight territorial districts for government services and electoral representation. The Constitution transformed the Cherokee nation into a procedurally oriented western-styled 
rational government—not a global phenomenon in early nineteenth-century world.

Second, despite modelling the Cherokee government after the United States, the Cherokee Constitution departs significantly from the U.S. Constitution in one major way. Unlike in the U.S. Constitution, the very first article of the Cherokee Constitution makes the statement on the boundaries of the nation's territory: "The Boundaries of this nation, embracing the lands solemnly guaranteed and reserved forever to the Cherokee Nation by the treaties concluded with the United States, are as follows; and shall forever hereafter remain unalterably the same to wit." Technically, a statement on the boundaries of a nation in a national constitution is redundant because while a constitution as the main law of the land aspires to hold complete influence within the nation's borders, its jurisdictional capacity does not extend over the boundaries or lines of the nation separating it from others. National boundaries in practice are determined by war or treaties or the combination of both. Nations, such as the United States, also expect to grow and thus tend not to limit themselves with a statement on the fixity of their territorial boundaries. But introducing the U.S. styled written constitution and the institutions associated with it was not only about adopting a certain form of governance for the Cherokee Nation; it was as much a calculated rhetorical move designed to resist the removal lurking over their head. As McLoughlin writes, "By 1827 [with the adoption of the written constitution], the Cherokees had learned so well the ideology of their conquerors that they were able to use it against them" (xviii). The territorial statement — while redundant from the scope of the constitutional genreembodied the purpose of the whole identification project that the Cherokee Nation was launching during that period. Given the history that the Cherokee Nation itself often was not recognized as a legitimate entity largely because agents of the United States could sign treaties with their favorable chiefs with inducements and bribery meant that the article would send a strong signal 
to both the Cherokee citizens as well as the outside audience: now, the Nation would not shed any land at all, and involving in the transaction would be automatically void, given the power of the constitutional genre. Certainly, the Nation had introduced a law for the same effect earlier in 1822 as well, but the inclusion of the statement in the epitomical genre of secular politic would bear a higher claim of legitimacy and power.

Scrutinizing further, the article on the territorial boundaries represents the depth of identification project at a new level. Instead of claiming the ownership of the land on the basis of the Cherokee's primordial association, which they would do later in their appeal to the United States Supreme Court, the article points to "the treaties concluded with the United States," as the source of their ownership. While such statement does not necessarily undermine the indigenous land ownership as not stating something is not equivalent to its absence, ${ }^{45}$ by using treaties - the privileged writings of the time- as the source of its ownership, the statement presents the Cherokees as a nation of writing formed in the tradition of Euromerican modernity. Besides, the reference to the treaties with the United States in the article also placed the moral responsibility of upholding the sanctity of the treaties - thus, of the territorial integrity of the Cherokee Nation - on the United States as well. Such politics of identification emphasized that the destabilization of the Cherokee land would not thus only be a disaster for the Cherokees but would also be a moral failure on the part of the United States as well.

\footnotetext{
45 The term "indigenous" holds different meanings in different historical contexts. It did not suggest the same kind of power in the early nineteenth century that the term embodies now, largely because of the postcolonial and indigenous movements of the late last century.
} 


\subsection{The Phase Two: Cherokee Public Campaign, the Claim of Improvement, and the Politics of Identification}

Besides transforming themselves into the image of the United States by constituting a nation-state and forming apropos cultural, institutional and public apparatus, the Cherokee Nation campaigned to influence the public opinion of the United States. As the debate on the Indian removal started, the Cherokees thought that persuading the public in the United States on the Cherokees' right to their land would lead the Congress to pass laws favorable to them. To that purpose, they systematically organized the campaign that "included sending Elias Boudinot and John Ridge out on speaking tours of northeastern cities, publishing the Cherokee Phoenix, submitting memorials to Congress, and drawing on aid of missionary organizations" (Konkle 44). ${ }^{46}$ The whole public campaign attempted to prove that the Cherokees had dramatically improved in civilization following the introduction of the Knox-Washington policy of Indian civilization and that removing them from their homeland would jeopardize the civilizing process itself. In the campaign, they also used their improvement as the counterclaim to the growing clutch of scientific racism that tried to project Native Americans as biologically unfit for the institutions of modernity and rational deliberations. They also appealed to American founding tenets such as republicanism and Christian morality, arguing how removing the Cherokees from their homeland would be against the moral fabric of the United States itself.

While the public campaign would intensify in the late 1820 s with the election of President Andrew Jackson, the Cherokees already had the threat of removal from as early the

\footnotetext{
${ }^{46}$ Boudinot and Ridge were young men well-versed in the Cherokee as well as white cultural norms. Both of them were educated in an English school located in Connecticut where they fell in love and later married with local white girls, irrupting controversy that led to the closure of the school itself. The education and experience made them effective "spokesmen" for the Cherokee cause (Sweet's term).
} 
1802 Georgia Compact that was becoming increasingly imminent in the 1820 s. Coinciding this development, the Cherokees had already started using any available opportunity for convincing the United States how removal was a bad idea. A case in point for instance is John Ridge's February 27, 1826 letter to Albert Gallatin, who had served in the Jefferson Administration as the Secretary of Treasury earlier and now was collecting information on American Indian tribes for his 1836 book. In the letter, Ridge compares the Cherokee past and present diachronically, and also the Cherokee's contemporary condition with that of neighboring whites synchronically. He then declares the progress that the Cherokees now "are farmers and herdsmen, which is their real character," as he "take[s] pleasure to state, tho' cautiously, that there is not to my knowledge a solitary Cherokee to be found that depends upon the chase for subsistence" (36). Now, as he insists, the Cherokee difference from his white neighbor had eroded as "their farm[s] are conducted in the same style with southern white farmers of equal ability in point of property" (41). He notes the marvelous swiftness with which the Cherokees had experienced the transformation: "And many a drunken, idle \& good for nothing Indian has been converted from error \& have become useful Citizens" (41). While the Cherokee syllabary was a recent invention, Ridge highlights how enlightenment had dawned on the Cherokees because of education: "I suppose that there are one third of our Citizens, that can read \& write in the English Language" (42). And the Cherokee ladies are as comparable as any elegant white middle class women: "Two Cherokee female have recently completed their education...they would pass for the genteel \& wellbred ladies in any country" (42). Most of this information, when read in the particular context of the correspondence between Ridge and Gallatin, is redundant for Gallatin's language-dominant ethnological project. But the macro historical context where Ridge found the threatened existence of his tribe catapulted him to go beyond the specifics of the Gallatin's book 
project. He used the opportunity instead to present a progress report so that he could change the public opinion of the United States through Gallatin's project. The closing section of the letter collects all the strength of the narrator's voice and presents the compelling reason behind the transformation of the letter into a progress report:

I draw to a close. Solemn \& gloomy is the thought that all the Indian nation who once occupied America are nearly Gone! Powerful in War and Sage in peace, the Chiefs now sleep with their heroic deeds silent, in the bosom of the Earth! It was not their destiny to become great. Their council fires could not be united into one, as the Seat of a great empire. It was for strangers to effect this, and necessity now compels the last Remnants to look for its protection. It is true we Govern ourselves, but yet we live in fear. We are urged by these strangers to make room for their settlement \& go farther west. Our National existence is suspended on the faith \&honor of the U. States, alone. Their convenience may cut this asunder, \& with a little faint struggle we may cease to be. (44)

Ridge's progress report ends appealing to the good "faith and honor of the U. States." His argument insists that the Cherokee had materialized themselves into the image devised by the Knox-Washington policy of Indian Civilization, and that now the moral responsibility of safeguarding the transformed Indian rested with the United States itself. Breaking the faith would not only undo the Cherokee civilization but would also be a failure of promise on the part of the United States. Protecting the Cherokee nation thus was as much in the interest of the Cherokees as was in the moral wellbeing of the United States itself.

If John Ridge's letter was a direct progress report, Elias Boudinot's editorials written for the Cherokee Phoenix took the ironic stance on the consequences of the Cherokee improvement. 
Instead of trying to prove that the Cherokees had progressed in the preceding decades, he assumes the progress a self-evident truth, and argues how the Cherokee attainment of civilization itself was the cause behind Georgia's decision to extend its laws over the Cherokee land. In his June 17, 1829 editorial, he writes that the extension of such law "might have been a matter of charity" in the past "when we were governed by savage laws." But the Georgian laws are extended now that the Cherokees "have established for ourselves a government of regular law" as "being fostered by the U. States, and advised by great and good men." He accentuates how the Cherokees had walked exactly on the footsteps of the United States, and for which "the aid and protection of the General Government have been pledged to us; when we, as dutiful "children" of the President, have followed his instructions and advice." Now that we "have established for ourselves a government of regular law; when everything looks so promising around us, that a storm is raised by the extension of tyrannical and unchristian laws." Boudinot, with dismay and sorrow, repeats the same idea forcefully in another editorial published on November 12, 1831: "But alas! No sooner was it made manifest that the Cherokees were becoming strongly attached with their land to the ways and uses of civilized life, than was aroused the opposition of those from whom better things would have been expected." He is convinced that, "the promises of Washington and Jefferson have" been aborted and that, "the policy of the United States on Indian Affairs has taken different direction, for no other reason than that the Cherokee have so far become civilized as to appreciate a regular form of Government." While the Cherokees had attained the state of civilization to appreciate and use their legal rights, "they are now deprived of rights they once enjoyed."

Boudinot's assessment of the cause of the extension of the Georgian law now, especially after the promulgation of the Cherokee Constitution where the nation claimed its complete 
sovereignty using the most powerful western genre of legitimization, touches the inner nerves of the white motivation. White America envisioned the natural attrition of Native American sovereignty. The Knox-Washington policy of Indian civilization expected that the Native Americans would either assimilate completely or sell their land and vanish in the wake of many other tribes. But the promulgation of the 1827 Constitution and the formation of a sovereign government by the Cherokees posed a unique challenge — an unexpected impediment on such belief. This attainment of the Cherokee modernity, as Lewis Cass-who would later serve as Andrew Jackson's Secretary of War-forcefully presented in his academic essays, needed an immediate action if the United States were to justifiably question the Cherokee sovereignty. Cass writes,

It is evident, that if this pretension [the Cherokee adoption of the constitution and their claim of sovereignty] be not resisted now, resistance hereafter will be in vain. It is of those questions, eminently practical, which a few years' acquiescence would settle. What might now be the assertion of a just and proper jurisdiction by the civilized communities, might then be an unjust claim to be enforced only by war and conquest. (119)

Cass understands the dynamics involved in the Cherokee politics of identification: The Cherokees were not transforming themselves into the image of the United States for their acquiescence, but rather were adopting the western methods of legitimization that would be difficult for the United States to resist after the solidification of the practices. The only way to prevent such option would be to delegitimize the 1827 Constitution and to remove the Cherokees from their land itself. Waiting longer to act would engrain the documents and practices of legitimization further, compromising the moral authority of the United States to question them as 
it is the similar genre conventions and practices through which the United States has instituted itself. Cass and Boudinot, though placed on the opposite isles of the struggle, understand the motivations involved in the identification project and responded accordingly.

From that perspective, Boudinot's editorials — while they present the Cherokee improvement as a self-evident truth requiring no further claim — took a more sophisticated angle rather than merely repeating the Cherokee public campaign's mainstream claim of the attainment of civilization. His approach is more rhetorically nuanced in the sense he calibrates his editorials in response to the intellectual developments in the western world, particularly on the nature of race and race relations. For instance, besides explaining how the Cherokee attainment of civilization was the cause of the Cherokees' imminent removal, his editorials also try debunk the scientific racism that, as Konkle demonstrates, was increasingly taking hold in nineteenthcentury western imagination. ${ }^{47}$ When Knox-Washington formulated the Indian Civilization policy, it assumed that the Native American cultural inferiority was the result of particular historical circumstances that could be ameliorated through specific programs. "Knox and Washington believed that the obliviously 'uncivilized' characteristics of Indian life existed because Native people knew no better. In other words, their 'inferiority' was cultural, not racial. Indians, therefore, were fully capable of becoming 'civilized' and assimilating into American society as functioning citizens" (Perdue \& Green 2005, 11). But as the nineteenth-century picked up, the western intellectual milieu started to establish the doctrine of Native Americans' innate racial inferiority, suggesting that Native American tribes were biologically incapable of civilization. Such sweeping doctrine automatically consigned all tribes into a single box, freeing the minds of having to dwell on the specifics of a tribe's progress for making any position. From

${ }^{47}$ See "Introduction" in Konkle's book. 
this new perspective, judging on the Cherokee civilizational progress had become a redundant exercise.

Boudinot perceives the monumental danger of this new doctrine to the efficacy of the Cherokee politics of identification and thus presents counterargument asking the readers to observe the specifics of the situation, cautioning them not to jump to stereotypically influenced, lazy and hasty conclusions. In his November 12, 1831 editorial, he notes the "customary charge" that Indians could not be civilized: "We have on more than one occasion remarked upon the difficulties which lie in the way of civilizing the Indians. Those difficulties have been fully developed in the history of the Cherokees within the last two years [difficulties arising from the Georgia's encroachment].” He claims that,

$[\mathrm{N}] \mathrm{o}$ one can now mistake the source[s] [of Native American wanting of Civilization] .... They are not to be found in the "nature" of the Indians, which man of high authority once said was as difficult as to change as the leopard his spots. It is not because they are, of all others, the most degraded and ignorant that they have been brought to enjoy the blessings of a civilized life.- - But it is because they have to contend with obstacles as numerous as they are peculiar.

He presents the success of the Indian Civilization program as the evidence against the doctrine of biological determination of racial progress. He reports, "With the commendable zeal of the first Chief magistrate of the United States undertook to bring the Cherokees into pale of civilization...his successor followed his example...The attempts of those good men were attended with success." The evidence of transformation is everywhere now: "Instead of wild and ferocious savages, thirsting for blood, they [the Cherokees] have become the mild "citizens."' This evidence - the evidence of Cherokee progress in the recent decades — univocally leads to 
the fact that "we have no example upon which we can build the assertion, that it is impossible to civilize and Christianize the Indian." Given how consequential the implication of the new racial doctrine would be to the Cherokee attempt to maintain its sovereignty, the editor relentlessly argues, "We have instances of nations, originally as ignorant and barbarous as the American natives, having risen from their degraded state to a high pitch of refinement." As he repeats in another February 19, 1831 editorial, it was not the biological or natural causes that would stymie the Cherokee process of improvement but the extension of the Georgia's law as "it forces from them the vary means of their improvement in religion and morals, and in the arts of civilized life."

As the Committee on Indian Affairs reported the Indian Removal Bill to both houses of the Congress in the early 1830, the Cherokee Public campaign took a tone of urgency. Now, unfortunately, the Cherokees realized that the fate of their sovereignty rested on the Congress' decision on the bill. To garner the support against the bill, they intensified their effort, often producing powerful statements through their newspaper that circulated in major American cities outside the Cherokee territory as well. For example, a Cherokee Phoenix article published on March 17, 1830, notes the bill and writes, "The question is therefore now open for discussion, and soon we shall hear what is to become of us." The article continues, "Crisis is at hand. Will justice prevail?" This question of justice was no more an abstract deliberation of after-life consequences or about the determination of petty everyday conundrum. It was about the "momentous questions which must in vary short time receive a practical answer." It was the question about justice: "If Justice prevails, the Indians will assuredly be protected. But if treaties are disregarded and declared of no validity, as many high in office have already done, then indeed shall we be delivered over to our enemies." The article adamantly opposes any attempt of 
the removal, "If therefore we are to be scarified, let the bloody tragedy be accompanied here on own native soil around the graves of our fathers \& in view of the people of these United States." Then comes the powerful final challenge to the people of the United States:

The good people of this boasting republic may stand and gaze on the oppressive acts of Georgia, consenting or not, as they please, to our destruction. It will not require their aid to destroy us - they need only stand still—Georgia can accomplish her design easily_But there will be reckoning hereafter.

Written amidst the compelling time with existential threats hovering over the Cherokees, the carefully chosen words in the statement for the maximum rhetorical impact reminded the people of the United States their principle of republicanism and their antipathy with any form of oppression. Just boasting about their republicanism would not be sufficient after reading the article; the article challenged the reader to actively exercise their principle by standing with the Cherokees. Passivity was not an option. Only by standing against the removal bill, the "good" people could fight the oppression exactly in the way their earlier generation had fought against the British tyranny. The characters and contexts might have changed, but the principle was not different at all. Not participating actively against the bill represented a serious breach in the ethos of the United States, but it also would lead to a "reckoning hereafter." The voice was as much of otherworldly Christian challenge to someone about to be derelict of a pious duty as was about the rupture of secular moral philosophy on which the nation was founded. The statement tried to touch the moral heart of the not-so-old nation, challenging it to be true to its "boasting" republican principles. The article further reminded the readers the hypocrisy of using one means instead of another to violate the Cherokee existence. "It is said, however, that the general Government and the state of Georgia, do not contemplate using force. We have never intimated 
that open force will be resorted to - this would be too barefaced." All legislative maneuvers and the pretension of just treaties to remove the Cherokees were merely feel-good factors for the removers:

The object is our removal, and if it is ever accomplished, it must be done contrary to our wishes and inclinations, by means which honor and justice forever reprobate. It makes no difference whether we are ousted at the point of the bayonet, or by indirect and oppressive measures - it is the same thing with us, and we wish the public know it.

Then, after the long explanation how the Cherokees and the people of the United States could not morally and legally accept the removal, the article directly addressed the people of the United States: "People of the U.S. our appeal is to you-Will you, with relentless hand, extinguish all our rising expectations?"

Responding to the Cherokee appeal, many white Americans took the Cherokee cause for themselves. They devoted themselves against the Indian Removal Bill by holding meetings, publishing memorials and pressurizing their representatives. While they used various lines of argument, the most striking and common among them was the idea that the Cherokees had progressed in civilization and thus they deserved the protection, respect, and sovereignty. In the abundant number of memorials written by the white supporters across various cities from Boston to Baltimore, the Cherokee politics of identification had caught on the fire-catapulting the Cherokees-coming-to-civilization a compelling case within the public sphere of the United States. For example, "the Representatives of the Religious Society of Friends, in the state of New York, and parts adjacent” singed a memorial on January 5, 1830 to the United States Congress against the proposed Indian Removal Bill. They highlighted the Cherokees' transformation 
"from a dependence on the precarious subsistence which the chase affords, to habits of civilized life, and have made great advancement in agriculture and domestic economy." Citing the Cherokee situation that the United States "threatened violation of their rights and privileges as distinct and separate people, recognized in numerous treaties of the government of the United States," the memorialists pointed to the moral fabric of "our beloved country." Characterizing the Indian removal plan as full of "injustice," the memorialists pointed at the reprobation that the United States would face if it commits the proposed injustice against the Cherokees.

We anticipate the opprobrium which will cast upon it in the eyes of the world, if it [the Indian Removal] should be consummated. And as national sins have, under the just government of a righteous Providence, drawn down national punishments, we tremble, lest when the Most High shall arise at the cry of the poor and oppressed, his arm shall take hold of vengeance. ..To avert these fatal results, and to prevent the total extermination of a much injured people, we... solicit the two houses of Congress to interpose their authority for the protection of the Cherokee nation in its just rights.

While the state might have been constitutionally separate from religion, the memorialists coalesced the theological and rational to make the case against the removal. In this fusion of traditions, the white campaign for the Cherokee cause become as much about the Cherokees' fate as about the soul of the United States.

"The citizens of Philadelphia, on behalf of the Cherokee" singed a memorial on January 11, 1830 that literally reinforced the Cherokee politics of identification. While their memorial strongly opposed the removal, it did not see the Cherokees possessing their own independence in the future. Certainly, the memorial highlighted the inviolability of treaty commitments, but the 
focus rested on the idea that the Cherokee would be assimilated if they were allowed to remain in their own land. Quoting the Cherokee "address to the President of the United States dated at Washington 12 March 1825," the memorial argued,

A few years the progress of civilization, and increase of knowledge, would of necessity change their [the Cherokee] character, modify their laws and customs, and finally prepare them [further] for the amalgamation with the white population. They would gladly receive the rights of citizenship, the duties of which an improved education would teach them to appreciate and perform. That this is the ultimatum of the hopes and wishes of the Indians themselves.

From this perspective, the Knox-Washington policy had remained effective; the Cherokee were working hard in transforming themselves to be worthy of the citizenship of the United States. For such grand attainment, the Cherokees were equivocal: "for the sake of civilization and the preservation of existence, they would willingly see the habits and customs of the aboriginal man extinguished." They have come a long way from their savage and barbaric past:

[T] he Cherokee, by the express recommendation, nay, by the aid and assistance of the Government of the United States itself, have, for a series of years past been rapidly advancing civilization - that they have relinquished the habits and pursuits of the savage, and have become possessed of houses and mills, flocks and herds, schools and printing presses.

And thus, it was not the time for turning the wheel of progress backward. What was missing in this argument were the governmental institutions, including the 1827 written constitution that the Cherokees had adopted for claiming their independence and sovereignty. Although this elapse was critical, it did not matter much because the memorialists were against the removal, and that 
was what the Cherokees wanted at that point.

In another memorial written against the Indian Removal, "the Citizens of Massachusetts, residing in all parts of the Common Wealth" did not see the assimilation a requirement for the United States to respect the Cherokees' continued existence in their homeland. The citizens certainly highlighted the recent Cherokee improvement, but they primarily concentrated their argument on the legitimacy of the Cherokee sovereign nationhood itself: The first treaty "made between the United States, and the Cherokees, the latter are not only called and considered as being a nation; but they actually exercise every one of the powers which we had enumerated, in the Declaration of Independence, as the highest attributes of national sovereignty." The way they framed the argument, the whole point of the Cherokee transformation into civilized lifestyle was to establish them as sovereigns in their own land. So, while the Cherokees had taken the United States' mission into their own heart, the main agent of transforming the Cherokees from wandering savages to nation-holding sovereign was the United States itself. What mattered now was the will of the Cherokees themselves, and on the question of the removal, "your Memorialists feel bound to say, that they have seen no reason, which satisfy them, that the removal of the Cherokee would be for their benefit." With the removal, "they would be thrown into a state of anarchy, and would lose the benefit of improvement already made by some of them, in practice of government." All attributes of civilization such as "subordination and public spirit" would disappear, and again "improvidence, contention, idleness, intemperance, and general profligacy" replacing the progress made recently. "The Progress of the education also, we fear must be interrupted." So, In conclusion, our " Memorialists do humbly entreat the National Legislature to interpose and deliver the country from all apprehension of violated faith, to redeem the sacred pledges of our national government. -to protect the defenseless aboriginal 
tribes." As the executive had failed to honor the past treaties, the Congress - the sovereign body of the people's representatives that had declared the Independence from tyranny in 1776 - had to act again according to the principle, honor and faith.

Perhaps the most important white campaigners against the Indian Removal from historical perspective were women. The cause gave white women the first major public voice in the history of the nation. ${ }^{48}$ Influenced primarily by William Penn essays, Catherine Beecher and Lydia Sigourney drafted the first petition against the removal that prompted thousands of other women from across the country to write memorials for the same effect. ${ }^{49}$ These women campaigners, the republican mothers, who were expected to mind their domestic duties instead of engaging in public discourse, found the boundaries between the two spheres blurred because of the moral question involved with the Indian removal. Protecting the hapless tribes was the matter of as much domestic as public morality. But again, despite many tribes facing the removal, the main example for the women's anti-removal argument became the Cherokees' progress itself: the Cherokees had progressed recently and that protecting the striving tribe was the moral responsivity of the nation built on republican principle and Christian cultural foundation. For instance, in Beecher's 'Circular Addressed to Benevolent Ladies of the United States" reads like a progress report on the Cherokee condition-not much different from the one written by John Ridge a few years ago. The circular insisted that Americans had to change the dominant perception about the Native Americans. Citing the Cherokees, the document stated that they were no more "naked and wandering savages." The differences among the Cherokees was not that of savage and civilized, but rather like the one among white population: "The various grades of intellect and refinement exist among them as among us; and those who visit their

\footnotetext{
${ }^{48}$ See Tiya Miles for the connection further.

${ }^{49}$ See Hershberger (25-28) for the wide range of appeals.
} 
chieftains, and families of the higher class, speak with wonder and admiration of their dignified propriety, nobleness of appearance, and refined characteristics as often exhibited in both sexes." The Cherokees had also progressed in political, economic and cultural realms substantially: "Among them are men fitted by native talents, to shine among statesmen of any land, and who have received no inferior degree of cultivation. Among them also, are those who by honest industry, have assembled around them most of the comforts, and many elegancies of life." So, while the imperative behind the women's participation in the campaign emanated from their traditional gender role as the guardians of morality that they tried to extend beyond the domestic sphere, it was the Cherokee progress that provided the impetus for the justification of their action. Not supporting a striving and improving group of people from punishment would be the breach on the moral fabric that gave the women a higher cause even when they were deprived of public political participation, including suffrage. In these women's petitions, the Cherokee politics of identification had come to bear a full force, gaining them the recognition of parity with the whites.

While an influential part of the Cherokee public campaign, particularly to generate the support from various Christian denominations, including the women petitioners organized around the benevolent ladies' organization, Jeremiah Evart's (written in the pen name William Penn) essays on the front appeared to be an exception. William Penn essays mostly focused on the Native American tribes' inherent right to their native land and the history of legal recognition of those rights by the whites. In his argument, he went to the extent that though the white establishment had recognized the sovereignty of the Cherokee nationhood, "such admission is in no sense necessary to the perfect validity of the Indian title" (106). For him, violating the already approved Cherokee nationhood and sovereignty by the United States and the state of Georgia 
would be "an instance of gross and cruel oppression..., and therefore entirely unjustifiable," irrespective of what the Cherokees did or where they stood on the ladder of civilizational hierarchy (107). His appeal to the idea of oppression deeply resonated to different sections of society in early Nineteenth-century American cultural imagination: Puritans automatically associated the idea with Roman persecution of early Christians and the pain and suffering of the Protestants during European Reformation that catapulted their emigration to America. Within the public sphere dominated with the ideas of republicanism, which was not completely antithetical to puritan views, ${ }^{50}$ the term 'oppression' not only reminded Americans the Revolutionary era emotions against the British oppression of American colonists but also intensified the unsettled questions of sovereignty between the states and federal government in antebellum America. The rhetoric of oppression touched the inner political and cultural nerve of American public sphere. It is notable that increasingly a dominant national cultural character that would see its full articulation in the mid-century letters by the giants such as Emerson and Thoreau, was forming around this theme that asked the people to assert their independence and to stand to power. Evarts' argument of unjustified oppression to the hapless tribe thus mobilized American public's ingrained pathos, reminding it of its historical victimhood in the past from oppressive government, and asking it to imagine itself in the place of vulnerable American tribes ready to be sacrificed at the clutch of an unjust power. And, it also reminded that such unjust sacrifice was not without consequences for the perpetrators. Even in the most oppressed condition, American Christians had hoped that divine wrath would ultimately balance the natural law, establishing ultimate poetic justice. But Evarts' essays suggested that now the oppressor would be the United States if it failed to honor the Cherokee sovereignty. Individually, only by participating in the

\footnotetext{
${ }^{50}$ See Longaker (pp. 24-28) for the contemporary connection between New England puritanism and republicanism.
} 
anti-removal campaign, people could atone the sin their country was about to commit.

But despite his attempt not to make the Cherokee improvement as a justification for the recognition of the Cherokee sovereignty over their land, Evarts cannot help himself:

Again, it is supposed, that the existence of a little separate community of Indians, living under their laws, surrounded by communities of white, will be fraught with some great and undefined mischief.... when the case is accurately examined, however, all the fog clears away, and nothing appears in the prospect but little tract of country full of civilized Indians, engaged in their lawful pursuits, neither molesting their neighbors, nor interrupting general peace and prosperity. (109)

Not only does the statement suggest that the Cherokees had made the progress by responding to the missionary and governmental civilizational efforts, it also imagines the future of a model community that could serve as an example of what could result from the active benevolence of the good people. Evarts' vision of just society emanated from both his Christian zeal as well as the sacred legal documents of the nation that he prized because of his role as a missionary and a lawyer.

Even after it was evident that the Cherokee politics of identification had failed to achieve its goal as the United States prepared for the removal that would lead to the Trail of Tears, many white northeasterners continued to publish letters asking the United States to rethink about the plan. Ralph Waldo Emerson for instance wrote a letter to President Martin Van Buren in 1838 opposing the Cherokee removal. Illustrating the picture of the imminent removal and the suffering it would generate for the Cherokees, Emerson faulted the United States for recognizing the "sham treaty," the 1835 Treaty of New Echota that accorded the façade of legality for the removal even when the overwhelming majority of the Cherokee Nation had rejected it. He 
painted the U.S. stratagem as "a dereliction of all faith and virtue, such as denial of justice, and such deafness to screams for mercy, [that] were never heard of in times of peace" (30). Representing "the heart's heart in all men" from Maine to Georgia, he wrote, "Sir, does the Government think that People of the United States become savage and mad? From their minds are sentiments of love and of a good nature wiped out?" (30). The letter reached the climax when Emerson characterized the U.S. government as committing a crime that had denied both the citizens of the United States and the Cherokee Nation of their country. In his conceptualization, a country was not merely a bounded territorial structure with a governing institution, but a moral superstructure safeguarding the spirit of the American Revolution as sanctified in the Declaration. In the Cherokee case, the government had failed the people: "We only state the fact, that a crime is projected that confounds our understandings by its magnitude - a crime that really deprives us as well the Cherokees a country; for how we could call the conspiracy that should crush these poor Indians our government?” (31). In this line of argumentation, the Indian Removal deprived not only the Cherokees of their sovereignty, but, even more significantly, the United States its republican values upon which it was founded. Now, the country had lost its own soul, degrading itself into a mercenary, colonial power.

This argument was not made outside the Cherokee public campaign, especially its politics of identification. In the very beginning, Emerson framed the letter discussing how the Cherokee had transformed themselves into a civilized community warranting his praise and an appropriate treatment by the United Stated for their achievement:

Even to our distant State, some good rumor of their worth and civility has arrived. We have learned with joy their improvement in social arts. We have read their newspapers. We have seen some of them in our schools and colleges. In common 
with the great body of the American People, we have witnessed with sympathy the painful endeavors of these red men to redeem their own race from the doom of eternal inferiority, and to borrow and domesticate in the tribe the inventions and customs of the Caucasian race. (29)

Although it is difficult to gauge how far the Cherokees themselves thought of the civilizing mission as the process of "redeem[ing] their own race from the doom of eternal inferiority," it is apparent that Emerson and other white Americans who opposed the removal based their argument primarily on the progress made by the Cherokees. The Cherokees' system of government, their constitution, and their education served as the major hallmark for supporting the cause. As the quoted passage above suggests, the Cherokees campaigned against the removal using newspapers and public speeches where they claimed their improvement, turning the United States' policy of Indian civilization into a politics of identification, which not only consolidated power within the Cherokee Nation, but also garnered support from many white Americans like Emerson.

\subsection{The Cherokee Politics of Identification on the Legal Front}

Once the Congress narrowly passed the Indian Removal Act that Andrew Jackson signed into law on May 28, 1830, the Cherokee Principal Chief John Ross submitted a lawsuit on behalf of the Cherokee Nation to the U.S. Supreme Court requesting the injunction against the federal government and the state of Georgia from executing the Indian Removal Act. The lawsuit claimed that the Cherokee Nation was an independent foreign country, requiring the United States to respect its treaty obligations and the Cherokee Nation's sovereignty. Chief Justice John Marshal delivered the consequential Cherokee Nation v. the state of Georgia verdict stating that the court did not have the jurisdiction on the case, while simultaneously defining the Cherokee 
nation as a "domestic dependent nation." However, in the 1832 Worchester v. Georgia case filed by the U.S. citizen Samuel Worcester, the Supreme Court affirmed the status of the Cherokee Nation as a foreign nation, with the ruling that the statues of Georgia could not be applied in the Cherokee territory. As it is well known, President Jackson did not respect the verdict as he did not change his mind of removing the Cherokees from their ancestral land even after the ruling. Scholars have widely commented on the Marshall's verdicts on Native American cases. However, not much have been written on the text of the lawsuits submitted by the Cherokees themselves. In what follows, I foreground the Cherokee side of the case and argue that both the Cherokee action of going to the Supreme Court and their text collectively perform the rhetoric of identification. With their move to the court, the Cherokees certainly further emphasized their attainment of civilization, but now their major line of argumentation also tried to establish themselves as a recognizable body within the western legal system. In the process, they transformed their vision of sovereignty, nationhood, and even identity.

From the perspective of the Cherokee politics of identification, their submission of the appeal to the U.S. Supreme Court itself represented a statement of where the Cherokees had arrived from the point of the drafting of the U.S. Constitution and the formulation of the federal Indian policy by the Washington administration. As Marshall's verdict on Cherokee Nation v. the State of Georgia states, Native Americans were the afterthought in the mind of the drafters of the Constitution gathered in Philadelphia. It never occurred to the framers that Indians would bring their cases to the U.S. Supreme Court. The Constitution thus held a huge blank space regarding the place of the Native Americans in the United States polity, leaving substantial room for judicial interpretation in the future. Backed by the nation-building work and public campaign that the Nation had accomplished in the previous decades, the petition mustered the courage and 
skills needed to be involved in the United States' constitutional and political apparatus. With the lawsuit, the Cherokee had hired the best available lawyer and had started a constitutional war to justify their sovereignty in a new political order, using the discourse of modernity. What they wrote in the lawsuit was certainly important, but the act of going to the court and using the privileged genre convention, processes and concepts represented a new zenith in the politics of identification. They could lose the case, but the action of inserting themselves within the western legal system claimed them as a party worthy of judicial protection. While the public campaign tested how far U.S. public could withstand its moral ground, the legal battle tested the strength of the country's founding principles such the separation of power, guarantee of a disinterested hearing at a court, and redressing of the harm caused by the power.

The submission of the petition marked the dramatic transformation in the way Cherokees conducted their international relations. Traditionally, the Cherokees did not solve the international or intertribal conflicts using Euro-American style of legal process; by submitting the lawsuit, the Cherokees embraced a new kind of international politics based on western constitutional and legal discourse. With the new move, the Cherokees spoke in the specialized language that the United States could understand and required to respond. Using our contemporary language, with the lawsuit and the whole politics of identification, the Cherokee Nation insisted on its participation to the same discourse community that white America belonged to. But the objective was not their submission to the master discourse in totality as the federal Indian policy anticipated. The assumption of the white discourse hinged on an understanding that "one is [and, could be] always simultaneously a part of several discourses, several communities, [and] is already always committed to a number of conflicting beliefs and practices" (Harris 19). Indeed, they realized that they could maintain their sovereignty only by 
deploying the discourse that was not originally theirs. They demonstrated the confidence they could master of the discourse of western modernity for the politics of identification. As Bakhtin argues, discourses do not belong to anybody automatically; they are acquired with hard efforts. ${ }^{51}$ Although the use of the discourse did not "guarantee that our utterances will be interpreted adequately or that we will interpret adequately the utterances of others," the Cherokee use of the western legal discourse insisted on the proper hearing (Kent 442). Participating in the discourse community of the United States by using the discourse of modernity for the Cherokees meant that while their national identity may be different, the underlining values that they practiced were similar with the United States. Therefore, while the lawsuit might bear the claim for an alternative sovereignty or non-allegiance to the United States, the underlying logic of the identification required the U.S. to recognize the voice of the Cherokees. Not recognizing the Cherokee voice in this context would be self-shattering - a kind of homicide, killing of one's own kind — on the part of the United States.

The politics of identification cast the Cherokees in Euro-American terms. For instance, they present themselves as the first discoverer of the land at one point in the lawsuit. They deploy western legal, cultural and economic concepts and structure of argumentation systematically first to delegitimize the white claim to the Native American land, and then to establish their ownership. For instance, the lawsuit engages with the history and process of granting land titles in colonial and national periods. Since European settlers' claim to the Indian land originated from the title they received from their king, the Cherokee argument resorts back to the origin itself first by directly rejecting King George II's legal authority to grant the title of the land that did not belong to the crown.

${ }^{51}$ See Bakhtin (294-95). 
That, in the year of the Christian era one thousand seven hundred and thirty-two, the monarch of several islands on the eastern coast of the Atlantic ocean, under the name and style of George II. King of Great Britain, by a charter to the company of his own subjects there residing, affected to grant them all the country on this continent lying between the Savannah and Alatamaha rivers. That this country was, at that time, occupied and owned by several distinct sovereign and independent nations of Indians, and among others, by the Cherokee Nation; and that the monarch who affected to grant it had no title to it whatever. (qtd. in Peters 26)

Structured in the binary between "distinct sovereign and independent [Native American] nations" and the European king "who affected to grant" the title without his proper authority, the lawsuit questions the source of white claim to the Indian land. The petition further indulges in the context of European encounter with Native Americans and uses the context to highlight how it did not warrant the king an authority to grant the title and how the people receiving the title did not fulfill the conditions required of a discoverer.

These complainants are informed, and believe, that the only title to which he pretended was derived from circumstances, that a ship manned by his subjects had, about two centuries and half before, sailed along the coast of the western hemisphere, from the fifty-sixth to the thirty-eighth degree of north latitude, and looked upon the face of that coast without even landing upon any part of it. (qtd. in Peters 26)

This compact sentence makes a number of statements simultaneously: first, it presents the complainants as informed people cognizant of Euro-American line of arguments. In the 
nineteenth-century context of the hierarchy of civilizations, such claim mattered, especially in the context where colonized people were denied their full rational, human agency. The cognizance in par with the European man or a claim to it established rational human self.

Second, the sentence reinforces its earlier statement regarding the king's lack of authority to grant title for Native American land. From the petitioners' perspective, it was just a "pretension," not a real ordinance worthy of a sovereign's prestige - thus unrecognizable by any rational court. Third, even if the king had the power to grant the title to the first discoverer, his subjects did not discover the Cherokee land in the proper sense of the term as they did not land upon any part of it. Not only does the lawsuit here present facts, but also questions the definition of discovery itself. The fact that the explorer did not land upon the land would resonate with the nineteenthcentury audience, particularly in the contemporary context infused with the discourse of improvement. The ideology of improvement emphasized that only those who improvedcultivated - the land had the moral and legal authority to own it. ${ }^{52}$ So, the discovery, from the perspective of this lawsuit would not mean merely obtaining a title from the monarch but inhabiting the land as well.

With this background, the suit deploys the doctrine of discovery for its own purpose. ${ }^{53}$ "This, we are informed and believe, has been called a title by first discovery; which is not true, even in point of fact, as against the Cherokee nation and other Indian nations: for they had discovered and occupied it long before the European ship had ventured to cross the Atlantic ocean" (italic original, qtd. in Peters 26). Given the indigeneity of the Cherokees, "discoverers"

\footnotetext{
${ }^{52}$ Both 1827 and 1839 Cherokee Constitutions use the language of improvement. In the absence of individual ownership, the claim to a land depended on one's investment on "improving" the land. So, the land ownership — while defined differently — emanated from the evidence of improvement.

${ }^{53}$ See Wilkins and Lomawaima (9-63) for the indigenous perspective on the doctrine of first discovery.
} 
would not be a proper designation for this Native American tribe. But they assume the mantle of discoverer in their attempt to establish themselves as proper subjects identifiable by EuroAmerican legal culture, particularly to claim the ownership of the land. The assumption of this designation is symptomatic of the Cherokees' larger politics of identification at deeper conceptual level.

Besides adopting the doctrine of first discovery, the lawsuit also foregrounds the instances from Euro-American legal and legislative history that respected the Indian sovereignty to expand on their argument. It, for instance, highlights how the Charter of George the Second never claimed "that the grantees had the right to disturb the self-government of the Indians who were in possession of the country" (qtd. in Peters 26). The petition further reiterates the recent developments, particularly the treaties between the United States and the Cherokee Nation, including the one signed in 1816, that the United States Congress "duly ratified and confirmed ..., and became thenceforth, and still are, a part of the supreme law of the land" (Peters 26). The lawsuit also narrates the long history of treaties in which the United States promised "the Cherokee to a greater degree of civilization" (Peters 26-27). Then the suit recounts how the Cherokees have established a republican form of government for which they borrowed the main characteristics from the Constitution of the United States. As a contemporary Supreme Court reporter describes,

They have formed a code of laws, civil and criminal, adapted to their situation.... they have established schools for the education of their children, and churches in which the Christian religion is taught; they have abandoned the hunter state and become agriculturalists, mechanics and herdsmen; and under provocations long 
continued and hard to borne, they have observed with fidelity, all their engagements by treaty with the United States. (Peters 27)

The lawsuit reaches the pivotal moment when the plaintiffs claim that they have reached—or surpassed — the project of civilization designed for them. They had progressed to the point that they could assert "they are willing to submit to a comparison with their white brethren around them" (Peters 27). Now, with this scaffolding of evidence and arguments, they request the court for the injunction against the executive branch of the United States and the State of Georgia from enforcing the Indian Removal Act.

While the Cherokee public campaign failed to garner enough support in the Congress,

they won the legal battle. In the 1832 Worcester vs. Georgia verdict, the Supreme Court affirmed the Cherokee sovereignty. Jackson administration had to compel the Cherokee Nation for another treaty if it were to maintain the façade of legality for the removal. Thus, there was the 1835 Treaty of New Echota. After the 1835 treaty was approved by the senate with one vote and the United States and the state of Georgia started the removal process forcibly, a large section of the public interpreted the treaty as fraud ( Fleischmann 35-45), including the foreign press ridiculing the United States “cynically about 'a government founded upon such lofty principles' having its 'deviations exposed to public scrutiny"' (Fleischmann 47), prompting representative Horace Everett of Vermont to propose the amendment on the senate's treaty resolution.

\subsection{Cass-Jackson Rejection of the Cherokee Consubstantiality}

Even those who did not want to acknowledge the Cherokee politics of identification had to respond to it, largely because of the storm with which it swarmed the public sphere of the United States during the Andrew Jackson Administration. The politics of identification was so powerful that the administration needed to nullify the claim of the Cherokee improvement to 
justify the removal. Stepping to this exigency, two of the most prominent contemporary politicians Andrew Jackson and Lewis Cass offered powerful rebuttals to the Cherokee claim of civilizational attainment. Lewis Cass, who would be Jackson's Secretary of War in 1831, wrote an "extended reviews of books and articles" (Perdue and Green 115) in the January 1830 subscription of the North American Review. Designed to debunk the "exaggerated representation" that "the constitution of the Cherokee, their press, newspaper, and alphabet, their school and police, have sent through all our boarders the glad tidings, that the long night of aboriginal ignorance was ended, and that the day of knowledge had dawned," the essay sets to keep "the truth" straight (117). The truth is that the "wish [of Indian civilization] is vain" (116). Cass praises the efforts of white "zealous and pious men" to the cause of Indian civilization, and their "generous ardor to the task of instruction, as well as in agriculture and mechanic arts, as in principles of morality and religion" (116). But he declares, "Unfortunately, they are monuments also of unsuccessful and unproductive efforts" (116). The failure does not originate from "the nature of experiment" or "the character, qualifications, or conduct, of those who have directed it" but "some insurmountable obstacle in the habits or temperament of the Indians, which has therefore prevented, and yet prevents, the success of these labors" (116). The truth is that "existing for two centuries in contact with a civilized people, they have resisted, and successfully too, every effort to meliorate their situation" to the point that "their moral and intellectual condition have been equally stationary" (118). Thus, the recent Cherokee assertions of the attainment of civilization - particularly the nation's declaration of constitution "claiming legislative, executive, and judiciary powers, and all essential attributes of sovereignty" - are merely "pretensions" (119) or a "scheme" (121) or "a false conception of their own interest" (119). Assuming that any Native American claim of civilization univocally ends with the tribe's 
submersion into the body politic of the United States, Cass challenges the Cherokees to submit to the laws of the state of Georgia if they were truly civilized: "If he has advanced in knowledge and improvement, as many sanguine persons believe and represent, he will find these laws more just, better administered, and far more equal in operation, than the regulation which the chiefs have established and are enforcing" (120). The failure to submit thus is tantamount to the absence of civilization and claim of sovereignty: "If these Indians are too ignorant and barbarous to submit to the state laws, or duly estimate their value, they are too ignorant and barbarous to establish and maintain a government which shall protect its own citizens, and preserve the necessary relations and intercourse with its neighbors" (120).

Unlike the Cass essay aimed at white academic readers, President Andrew Jackson's letter signed on March 16, 1835 directly addresses "the Cherokee Tribe of Indians East of Mississippi," urging them to remove from their ancestral homeland with the disapprobation that the Cherokees had failed to civilize themselves. Not germane to the occasion of the letter itself, yet demanded by the broader context, the letter stacks evidence to counteract the Cherokee claim of civilization and equality.

Most of your people are uneducated, and are liable to be brought into collision at all times with their white neighbors. Your young men are acquiring habits of intoxication. With strong passions, and without those habits of restraint, which our laws inculcate and render necessary, they are frequently driven to excesses which must eventually terminate in their ruin.

Besides this absence of education, restraint, proper impulses and appropriate neighborly manners, the letter also points to the factionalism within the Cherokee Nation: "a divided people you now are, arrayed into parties bitterly opposed to each other.” Also, lacking among the 
Cherokee is the cornerstone of civilization - the property: "a large portion of your people have acquired little or no property in the soil itself, or any article of personal property which can be useful to them." Then finally, comes the moral indictment: The Cherokees had exceeded the "the reach of moral evils which are hastening your destruction." Jackson continues, had you removed earlier following the "wisdom of this [my] council" you "would have been governed by your customs and laws, and removed from the effects of a white population." But since the Cherokees did not heed to the council, "Where you now are, you are encompassed by evils, moral and physical, \& these fearfully increasing." Your condition has worsened, "and you will ultimately disappear, as so many tribes have done before you." So, the only option for the addressees again is to "listen to me" because "I tell you that you cannot remain where you are now. Circumstances that cannot be controlled, and which are beyond the reach of human laws, render it impossible that you can flourish in the midst of a civilized community." Summarizing the whole argument, Jackson, the ultimate political clout to recognize literally the Cherokee attempt at identification with western modernity, refuges the recognition phrasing the Cherokee's transformed way of life "your peculiar customs" instead of appreciating their mimicry of U.S. inspired republican form of government: "Your peculiar customs...have been abrogated by the great political community among which you live; and you are now the subject of the same laws which govern the other citizens of Georgia and Alabama." Subtly playing within the logic of hierarchy of civilizations and denying the Cherokee argument of improvement and request of recognition from the United States on the basis of that improvement, Jackson's letter refuses to acknowledge the Cherokee adoption of modernity. 


\subsection{Late Twentieth-century Cherokee Constitutional Rhetoric: From Subjection to}

\section{Sovereignty}

For the Cherokee Nation, being responsive to shifting reality and transforming its politics to match the historical need for its survival, sovereignty, and self-determination was not merely the nineteenth-century phenomenon. As the drafters of the 1976 Constitution envisioned, particularly by introducing the provision of mandatory constitutional amendment by each generation, the Cherokees articulated themselves as a nation of growth-not something frozen in the past or totally shaped by the dictates of the ancestors, but as a living and self-perpetuating people. Indeed, at the core of this spirit lies the instinct for self-translation, the ability to contextualize its cultural values and history for new situations. Rennard Strickland captures this essence succinctly: "Each generation has created and re-created the Cherokee in the image of that age.... Ironically, this mythical Cherokee looms so large today that the real one is in danger of being forgotten by many Indians and by much of white society that has come to believe many of these often-contradictory myths" (qtd. in Justice 1). As Strickland points, the mainstream dominant narrative often portrays the Native American cultures in mythical terms without recognizing their historicity — and the human agency involved in that historicity. But, as Leslie Marmon Silko writes of Native Americans, if they were to survive, their ceremonies should grow (105). "The genius of Native American culture was its ability to persist shifting regimes and the conditions imposed by colonialism" (Hoxie 138). Although the theory of linear progressive history from ignorance to enlightenment as enshrined at the core of modernity, and the evolutionary narratives that this vision encourages, may not characterize this transformation, the Cherokee constitutional history-particularly the experiments of the last quarter of the twentieth century — presents them as a culture defined by the being-in-becoming, the idea that their being 
or identity is marked by the awareness of historical context and the will and practice of transforming themselves to make the best as afforded by the context. ${ }^{54}$

True to the spirit of the name of the Nation's first official newspaper Cherokee Phoenix, the Cherokee Nation's constitutional accomplishments of the last quarter of the twentiethcentury that culminated in the introduction of the 1976 Constitution and its amendment in 1999 reemerged from the ashes: the Indian General Allotment Act of 1887 that distributed the Cherokee Communal land in Oklahoma for their private ownership virtually destroyed the Cherokee Nation already devastated by the U.S. Civil War. After the United States started handpicking the Cherokees' Principal Chief in 1907, any semblance of the Nation's sovereignty perished. The mid-twentieth century Indian termination policy attempted to relinquish Native tribes' special recognition as they were tried to be brought under the complete jurisdiction of the states. But the 1960s — with its own multiculturalist spirit — also witnessed the movement for the Native American self-determination, embodied mostly by AIM (American Indian Movement) and other Native activist organizations. As a result, Congress passed many legislations, including the 1975 Indian Self-determination and Education Assistance Act, to terminate the mid-century policy of Native American assimilation. It is in this historical background, the Cherokee Nation introduced a new written Constitution in 1976 that was amended in 1999.

In this section, I read the 1976 and 1999 Cherokee Constitutions by placing them in their historical contexts. As stated in the introductory chapter, while a genre exerts some of its traits in almost all situations, context shapes the genre functions, making them rhetorically nuanced performances. Adopted under the aegis of the Bureau of Indian Administration, the 1976 Constitution embraced the prototypical constitutional form recommended to the Indian tribes by

54 “Being-in-becoming” is LuMing Mao's term theorized in Reading Chinese Fortune Cookies. 
the U.S. Promulgated without a constitutional convention, the 1776 Constitution was selflimiting, particularly in its provision of the approval from the president of the United States for its amendment. ${ }^{55}$ Despite this subjection to the United States and the Nation's history of powerlessness, the Constitution itself however was an expression of the Cherokee sovereignty: it did not only remind us that the Cherokees are a distinct people with own history, but also served as a harbinger of the new time; having the written constitution symbolically manifested a distinct Cherokee identity. Besides this function, the 1976 Constitution also included the Article IV, Section 9 with the provision that the question of the constitutional amendment "shall be submitted to the members of the Cherokee Nation at least once in every twenty (20) years." The provision opened a space for the Constitution to transcend its own limitation; the 1999 Constitutional Convention, for instance, annulled the provision of the United States' approval requirement for its amendments, added a new statement of sovereignty, and envisioned a new form of nationhood that would enhance the opportunities of representation for its citizens. Because of these changes, the 1999 Constitution embodies the power of revision, a shift from the state of subjugation to a declaration of sovereignty. The 1999 Constitution goes even further: Using the affordances offered by new communications media, the Constitution envisions a deterritorialized nationhood in which non-residential Cherokees can also participate in the Cherokee Nation's government without having to give up their engagements in their locations. While the vision is still embryonic, the 1999 amendments sufficiently gesture toward new form of digitalized deterritorialized sovereignty and nationhood that can be an inspiration for many other nations mulling over the porous boundaries brought about by the forces of globalization.

55 See Lemond (313-14) for Ross Swimmer's reflection on the context of the 1976 Constitution. Swimmer, Principal Chief in that period, highlights Cherokees' own understanding of the tribe's imitated power even in handling its own issues. 
Before elaborating on digitalized deterritorialized sovereignty conceived in the 1999 Constitution, a close examination of the difference between the two Constitutions regarding their statements on sovereignty is in order. No provision in the Constitutions speaks better than their preambles on the state of the Nation's sovereignty. When sent for the ratification, the Nation provided the citizens with both the 1976 and 1999 Constitutions along with the summative information on the amendment. Commenting on the revision in the preamble, the document notes, "No substantive changes, just stylistic changes." Here is the preamble from 1976 Constitution:

We, the People of Cherokee Nation, in order to preserve and enrich our tribal culture, achieve and maintain a desirable measure of prosperity the blessing of freedom, acknowledging, with humility and gratitude, the goodness of the Sovereign Ruler of the Universe in permitting us so to do, and imploring his aid and guidance in its accomplishment do ordain and establish this Constitution for the government of Cherokee Nation. The term "Nation" as used in this Constitution is the same as "Tribe."

The 1999 Constitution revises it in the following words:

We, the people of the Cherokee Nation, in order to preserve our sovereignty, enrich our culture, achieve and maintain a desirable measure prosperity and the blessing of freedom, acknowledging with humility and gratitude the goodness, aid and guidance of the Sovereign Ruler of the Universe in permitting us to do so, do ordain and establish this Constitution for government of the Cherokee Nation. While claimed as merely a stylistic change, the amended preamble not only includes a powerful statement of sovereignty but also eschews the self-limiting "tribal" adjective by adopting a 
broader identity of nationhood. When viewed in the legal context, the accentuation of tribal identity in 1976 Constitution reinforced the regulatory parameters established by the United States. By preferring nation to tribe, the 1999 Constitution sets the tone differently for the Nation's sense of itself and its relationship with the United States of America. When theorizing the sovereignty statement of a "domestic dependent nation," we should not merely consider the actual material condition prevailing at the time or the declarative statements for their denotative meanings alone, but also the connotations suggested between the lines. Only by being attuned to those suggestions, we can understand the notion of sovereignty as a dynamic, protean phenomenon as much practiced at present as is wished differently for the future. By striking down "tribe" for "nation" and by including a powerful statement on sovereignty, the amended preamble encapsulates not only the Nation's sense of its past and present, but also its dream for the future. Reading in this manner, it can be said that the Cherokee vision of sovereignty is an unfinished business, a work-in-progress. In a sense, the amended preamble reminds us of the Cherokee Nation's 1831 Supreme Court petition to be recognized as a foreign nation. While the "constraints" in their rhetorical situation-being within the boarder of the United States and the historical fact of their subjugation and occupation — does not allow them in 1999 to declare the kind of sovereignty that the 1831 Supreme Court petition demanded, the amended preamble gestures toward that desire. ${ }^{56}$

More instructive on the new Constitution's spirit of sovereignty is the Article no.1 (one), immediately following the preamble. The article in the 1976 entitled "Federal Regulation" reads, "The Cherokee Nation is an inseparable part of the Federal Union. The Constitution of the

\footnotetext{
${ }^{56}$ I'm using "constraints" in the sense as theorized by LIoyd Bitzer in his consequential 1968 article "The Rhetorical Situation," in which he characterizes exigency, audience, and constraints as three major components of the rhetorical situation.
} 
United States is the Supreme Law of the land; and therefore, the Cherokee Nation shall never enact any law which is in conflict with any federal law." The revised article in the 1999

Constitution shifts the title from "Federal regulation" to "Federal relationship," and redefines the nature of relationship from that of the regulator and regulated to the one between two equal partners: "The Cherokee Nation reaffirms its sovereignty and mutually beneficial relationship with the United States of America." Cumulatively, the amended preamble and the Article 1 (one) make a powerful statement on the state of Cherokee sovereignty as something that is not subservient to the sovereignty of the United States.

Scholars have emphasized that Native American sovereignty should be analyzed in terms of white colonialism, Native resistance, and tribal peoples' effort for their self-determination. ${ }^{57}$ It is thus understood to be relational with the United States. Because of this reason, as Scott Richard Lyon has demonstrated, Native American sovereignty is rhetorical in nature, and only by having "rhetorical sovereignty" with "a people's control of meaning" that can be "found in sites legal, aesthetic, and pedagogical" (447) that Native American tribes can ensure their selfdetermination. As Alyosha Goldstein states, tribal sovereignty "is not a question of having or not having some transhistorical or universal thing," but "a necessarily relational and interdependent

\footnotetext{
${ }^{57}$ For Fredrick E. Hoxie, "the term [sovereignty] is perhaps best understood not as a fixed legal status or condition but as a category of analysis" (141). For him it is about the "condition of autonomy that might apply to any area of life" rather than "simply ... condition of political life" (140). In the same vein, Jodi Byrd thinks of sovereignty as "the force and rule of law whether it is bound to spiritual deity, an individual, and entire population, or a piece of land" (131). For her Indigenous sovereignty is "the power and capacity to dictate selfhood in the face of settler colonialism and across four centuries of liberal enlightenment" (131). Joseph William Singer thinks that the map of the United States has erased the Native sovereignty as it does not reflect the 566 federally recognized tribes (1-18). Manu Vimalassery argues that tribal sovereignty is something primal that existed from pre-contact era against which United States makes it sovereignty claims, which he terms as "counter-sovereignty" (142). Sovereignty is also about "a political entities externally recognized right to exercise final authority over its affairs" (Biersteker \& Weber 2).
} 
set of claims and strategies that are made and mobilized in specific times and circumstances with regard to particular antagonism" (148). In the tradition of Euro-American modernity, the sovereignty of a nation is expressed by the sanctity of its territorial boundaries. Its direct implication can be seen in the international borders - particularly, unresolved fault lines - that nations police for stopping any infiltration. Even when an infiltration does not create any pragmatic difficulty, such encroachment generates high nationalist furor as it is interpreted as a direct assault on the nation's sovereignty. Ideologically, an individual ownership of property and the national claim of territory have similar roots in modernity. Given the rationality involved in the conception of modern nation-state that required it to stand above ethnic and linguistic bases, the territoriality served as the determining factor for the nation-states. As stated above, Native Americans did not practice property ownership in the way European modernity - as in John Locke's treatise - conceptualized it. Native Americans have had a spiritual and indigenous relationship with the land, a connection that should have been translated into European conception of sovereignty comfortably, especially from the European perspective. But Native Americans did not have the identical conception of territorial sovereignty, a reason that many Native American tribes shared their land with early colonial settlers. But as they lost their land substantially and the fear of losing all land emerged, some of the tribes saw the value in constituting them as territory-based nations. As a part of their politics of identification, the 1827 and 1839 Cherokee Constitutions, for instance, stated the territorial sovereignty as their major characteristic, although the Constitutions did not embrace the full spirit of a territorial nationstate as only the people with the Cherokee ancestry could be its citizens. While selfdetermination is still at the core of the Cherokee struggle in the early twenty-first century, the factors in the new context such as dual citizenship, dispersed population, limited land-base and 
digital technology have instigated the need for new vision of nationhood and sovereignty, leading the Cherokee Nation to be rhetorically creative in its articulation of its sovereignty.

Thus, because of having to redefine its sovereignty according to the broader historical context and the rhetorical exigency and kairotic opening available in that context, Cherokee Nation in the 1999 Constitution not only presents strong statements on sovereignty, but also expands it to a more nuanced form, one marked with the spirit of deterritorialization and digitization. The Article VI, Section 3 allocates two seats at the National legislature, National Council, to be elected "by those registered voters residing outside the boundaries of the Cherokee Nation voting at-large in according with this section." Before the 1999 amendment, the Cherokee Nation's nonresidential citizens could vote for the National Council only being registered in a territorial district. Lifting of that requirement freed the citizens from having to be artificially registered to a territorial district. As it can be expected, this development did not come in vacuum; it suggested the availability of communicational and connective infrastructure among the people and the Cherokee government. The Article VI, section 10 states, "The Council shall establish a continuous system of permanent publication of all laws of the Cherokee Nation and judicial opinions of highest court. The system shall provide for regular updating, indexing and digesting and shall be of public record of all times." In the historical context where the constitution was amended, the significance of this article transcends the traditional "right to information" kind of interpretation. Understood in the context of the existence of an active official website of the Cherokee Nation and its ability to bring its citizens, irrespective of their residential condition, on a single space, this article represents the shifting conception of nationhood - a deterritorialized, virtual nationhood. While attributing the quality of deterritorialization to the sovereignty of a Native American Nation with its aboriginal claim to 
the land may induce an automatic opposition, my theorization rests on the digitizing trends in the Cherokee Nation's practices and the provision of non-resident citizens' representation to the Nation's legislature in the 1999 Constitution. In a sense, the virtual platform that the Cherokee Nation is using supplements the territorial limitation imposed on the nation. Through the platform, the Cherokee citizens - irrespective of their geographical location — can participate with the activities of the nation, an imagined community collectively formed by the shared history, language and culture. While the Cherokee Nation may not have articulated this new conception of nationhood in clear words and the Constitution itself may not have fully exhausted the possibilities inherent in such conception, the provision of non-residential representation in the National Council and the use of virtual platform to bring the Nation's citizens in a single space point to that direction-something other nations could follow, particularly in a globalized world with flowing population.

Two contextual aspects inspired the digitalized deterritorialized sovereignty in the 1999 Constitution: dispersed population and digital affordances. From the time of the promulgation of the 1976 Constitution, the Cherokee Nation had faced a puzzle of how to ensure the representation of non-residential citizens to the Nation's structure. Triggered by the Dawes Act of 1887, which allotted the Cherokee Nation's communally held land for individual ownership, the Cherokee population has dispersed widely from one coast to the other, often making small satellite communities. Had the Cherokee Nation been a completely a standard territorial nationstate, the dispersal would have ruined the possibility of its reemergence as a Nation. Ancestral relationship, interpreted in terms of blood quantum, has been the basis of the Cherokee Citizenship. ${ }^{58}$ Even amidst the wide dispersal, the people-nation nature of the nation always kept

${ }^{58}$ See Sturm (2-4) for challenges facing a blood-based nation in the context of increasing 
the nationhood for the Cherokees even in the most powerless condition. A note of explanation is order here: the notion of a blood-based nation and the practice of blood quantum in identifying people may evoke an essentialist, non-rhetorical image, often pointing to a purist, atavistic tribal desire. But, as the 1999 Constitutional Convention - in course of discussing the blood quantum qualification for the candidate of Principal Chief that finally decided against any specific

interracial marriages. As Sturm's ethnographical study suggests, the blood-based nationhood rests on certain historically constructed conception of ancestry. Blood, when used as a source of citizenship, becomes rhetorical in nature as an applicant to citizenship has to persuade the authority for one's eligibility using the existing blood-based criteria. The Resolution issued by the Joint Council of the Cherokee Nation and the Eastern Band of Cherokee Indians on April 9, 2008 is particularly relevant here: while it acknowledges that hundreds of groups claim themselves as Cherokees and does not dispute many of their Cherokee ancestry, the resolution states, " any individual who is not a member of federally recognized Cherokee tribe, in academia or otherwise, is hereby discouraged from claiming as a Cherokee, or on behalf of Cherokee citizens, or using claims of Cherokee heritage to advance his or her career or credentials." As Todd Crow reports in Cherokee Phoenix on February 2, 2012, "According to a Jan. 25 U.S. census release, people claiming Cherokee linage on their census forms increased by more than 89,000 to 819,105 since the 2000 U.S. census." So, the blood for the citizenship is not so much about the ancestral Cherokee blood as is about the particular Cherokee blood discursively produced by the federal recognition and reinforced by the 'privileged' Cherokees themselves. The blood line with the access to the Cherokee citizenship thus rests on the writing established in legal, economic and cultural discourse, polishing the boundaries of the Cherokee identity. As Robert Wald Sussman argues, racial and ethnic identity does not withstand the rigor of scientific analysis. From one perspective, such kind of claim may empower the races and ethnic communities deemed to be intellectually inferior by the nineteenth-century pseudoscience of racial biology that was used to justify colonization and subjugation. Race, as Stuart Hall argues, is a "floating signifier" discursively produced by language, power, and history, with different inflections in its meaning and impact in different socio-economic and historical contexts. Even the liberal discourse of meritocratic individualism may find the collective racial identity antithetical to its non-discriminatory philosophy, often interrogating affirmative provisions. But, as Cornet West boldly entitles his book, "race matters," particularly for those underprivileged whose identity needs to be redefined for their liberation and self-determination. As the Rachel Dolezal — who allegedly claimed African-American identity despite both of her parents' European ancestry - case demonstrated, the constructed nature of race or ethnicity does not mean that it is open for assumption to anybody (Victor, Daniel. "Spokane N.A.A.C.P Leader Posing as Black, Parents Say" New York Times, June 12, 2015.). Indirectly commenting on the case, President Obama, in his Amazing Grace Eulogy delivered on June 17, 2015, connoted that "grace," which many heard as "race" of African Americans is given, not earned (https://www.youtube.com/watch?v=x9IGyidtfGI). 
quantum requirement - displayed, the purity and degree of blood itself is the matter of convention. While a few delegates repeatedly evoked a particular image of Cherokee appearance saying that they don't want somebody not-looking-like-a-Cherokee to be their Principal Chief, the Convention deliberated on the future of any ancestry-based blood formula and highlighted the possibility of ever-reducing blood quantum of its citizens because of the increasing interracial births. Given the dispersal and the contact with the people from other ethnic and racial backgrounds that the dispersal brings, specifying the blood degree would be exclusionary as well.

By introducing the provision of representation to the National Council from the citizens residing outside the Nation's boundaries, the 1999 Constitution instituted a new form of sovereignty that would participate in the virtualization introduced by digital technology. The Cherokee blood may be in itself a rhetorically produced historical formation, it is the basis of the Cherokee citizenship. As the Cherokee Nation's website states, for the current form of the Cherokee citizenship "it requires that the applicant to the citizenship has at least one direct Cherokee ancestor listed on the Dawes Final Rolls, a federal census of those living in the Cherokee Nation that was used to allot Cherokee land to individual citizens in preparation for Oklahoma Statehood.” But this condition also poses a challenge for the Nation as it has to incorporate all interested Cherokee citizens in its nation-building process. While philosophically a people-nation, the Cherokee Nation also operates like a territorial state in its governmental structure and services; its limited land-base and the scattered population outside the base does not allow it to bring all citizens within a single territorial boundary. The advent of digital technology provided a new structure through which people could engage with an organization or a cluster of activities synchronously irrespective of their geographical location. Given the nation- 
people nature of the Cherokee Nation and its scattered population, the new digital virtual platform with its ability for "time-space compression" provides the Nation with a functional imagined community of collective identity and politics, by complementing to the Nation's limited land-base. ${ }^{59}$

Virtual supplementation is something fundamental to human existence. As Jacques Lacan theorized, human difference from the rest of the primates depends on human capacity to associate itself with the symbolic other. ${ }^{60}$ Or, drawing on rhetorician Kenneth Burke, human beings are primarily "symbol-using animals." Writings, arts, and other human endeavors do not merely represent the world, but also create their own reality. Twenty-first-century digital platform accentuates the human capacity for virtualization to a new level, disrupting old concepts such as territorial-sovereignty, while inaugurating new forms. Theorizing virtualization, Pierre Levy writes, "the virtualization can be defined as the movement of actualization in reverse. It consists in the transition from actual to the virtual, an exponentiation of the entity under consideration. Virtualization is... a change of identity, a displacement of the center of ontological gravity of the object considered" (26). He further writes, "virtualization fluidities existing distinctions, augments the degrees of freedom involved, and hollows out compelling vacuum" (27). Commenting on the impact of information technology, he writes, "taking a profoundly actual constraint (time and space) and making it a contingent variable clearly involves the creation of an effective solution to a problematic and thus of virtualization" (30).

Deterritorialization is the natural impact of virtualization: "It was therefore to be expected that deterritorialization, the escape from 'here' and 'now' and 'that,' would be encountered as one of

\footnotetext{
${ }^{59}$ See Harvey (pp. 260-307) for the concept as it relates to modernist and postmodern time. Also see Warf (pp. 194-199) particularly for the Internet's impact on time-space realignment. ${ }^{60}$ See Lacan, pp. 3-9.
} 
the roads of virtualization" (Levy 30). Expanding on Marshall McLuhan's thesis that technology shapes human cognition, John Tinnell writes, "mobile world browsers make possible a way of seeing that we might call Internet vision — seeing the world through the lens of an immense range of Web Writing/media that has geotagged to the places we inhabit." Pointing how "the Age of Print is passing," and how the process of virtualization started with the technology of telegraph has intensified with the advent of the Internet, Katherine N. Hayles writes, "the interactions are dynamic and continuous, with feedback and feedforward loops connecting different levels with each other and cross-connecting machines processes with human responses" $(2,13)$. This new way of seeing, intensified virtualization, and deterritorialization have collectively ushered in the possibility of deterritorialized sovereignty in which people could effectively associate themselves with an organization, community and nation-state without necessarily being geographically in the place where the entity of association physically exists. The virtualization of nation opens itself to the people located beyond its territorial boundaries, facilitating the participation of people to the virtualized deep space. From the perspective of sovereignty, the classical version of which indicates human ability to participate in public organizations beyond their own personal affair, the virtualization enhances the possibilities of new connection and participation, especially of those located far-flung from the land-base of the nation.

The ubiquity of virtual presence of organizations and businesses now may blind us in noticing this grand transformation, the new kind of national imagination based on new forms of communications technology. As Benedict Anderson argues the modern nation-states are imagined communities with their roots in the print culture; people sharing the language could imagine themselves as the members of new community even without having to engage in a faceto face communication. As he interprets, the roots of territorial nation-states lay in the explosion 
of writing, printing and reading in vernacular languages. Putting it differently, nation-states, their sovereignty, and the vision of citizenship have been the forms of human imagination contingent upon particular historical formation. Arjun Appaduari contends that electronic capitalism revolutionizes the possibilities involved in what Anderson called "print capitalism." Not only it accelerates the flows of all kinds - from finances to ideas to people themselves - from one place to the other, electronic capitalism also provides the platform for synchronous presence and connection for territorially far-flung populace in its virtual realm. (For instance, my family scattered across continents is localized in a Viber page where all members communicate and share photos, videos, and messages. Despite the temporal and spatial differences among us, the instantaneous communication and sharing gives us a sense of familial togetherness and immediate connection.) It ushers in the new forms of imagination that do not have to comply with the boundaries of geography and time. As an illustration, Appaduari points at the new forms of diasporic experiences in which new immigrants - unlike the immigrants from preelectronically mediated communication era-keep their contact with their native communities intact, bypassing the old temporal and spatial distances.

But this development does not erase the importance of territoriality. Surfing the Cherokee Nation's website and participating in the national discourse using the virtual platform may provide users a sense of deterritorialization. But the virtualization of the nation - the use of interactive communications platform and the participation opportunities that it offers-does not erase or replace the nation's geographical territory; it only adds on a new dimension of activities or a field of actions. In a sense, the added virtual dimension is a deep space, grounded on real time-and-space. As scholars have noted, the online virtual platform — despite its deterritorialized nature-depends on global digital hubs, the metropolitan centers with cybernetic infrastructure 
that control and develop the platform. ${ }^{61}$ The digitization of nations has opened new avenues and new forms of challenges - like the ones posed by cyberattacks — in preserving the security of their information, but it hasn't reduced the significance of territorial control. In line with this understanding, the drafters of the 1999 Cherokee Constitution added a new article-article no. II (two) — with a statement on "territorial jurisdiction," a provision prominently present in the 1827 and 1839 Constitutions but missing in the 1976 Constitution. This reiteration of territorial sovereignty reinforces the idea how Nation's trans-territorial possibilities depend on national territory, analogous to the relationship between the metropolitan nodal points and the global digital platforms they operate.

\subsection{Conclusion}

Reading the Cherokee Constitutions in the boarder Cherokee constitutional history from rhetorical and genre perspective provides us with at least two insights. First, it makes evident that the written constitution remains the dominant legitimate space for the Cherokee Nation in its articulation of the vision of nationhood and sovereignty differently according to their kairotic horizons. Second, this difference establishes sovereignty as naturally rhetorical in nature that the forces of history and writing conventions bring into being. The constitutional genre's embedded capacity to form a nation offered the Cherokee Nation an opening to adopt the politics of identification in the 1820 s. Bereft of military power, they could use the written constitution and other genres, discourses and institutions of modernity as rhetorical instruments in their struggle for survival and sovereignty. At the turn of the millennium, the Cherokee Nation uses the written constitution not only to redefine its relationship with the United States but also to reorganize its internal vision and distribution of the sovereignty that is attuned to the spirit of

${ }^{61}$ See Malecki and Moriset (36-61). 
deterritorialization and digitization. What this deployment of the genre suggests is that the written constitution as a genre has served as a sovereignty generating agency—replacing the premodern divine authority, conceived differently in diverse cultures, on whose name sovereignty was predicated previously. This emergence manifests that any practice and conceptualization of sovereignty is rhetorical in nature, including those claims of non-rhetoricality attached with divinely ordained sovereignties. ${ }^{62}$ Therefore, while the function of the written constitution is contextually driven and thus is particularly inflected in a specific historical juncture, its ability to legitimize nations, to provide the space for the articulation of sovereignty, and to act in concert with other genres and field of activities are something fundamental.

${ }^{62}$ I'm using Jacques Derrida's insight here. Of Grammatology demonstrates how even the claims of non-textuality has textual nature; oral exchanges are written structures. The deconstruction of oral-written binary is of significance for my project because rhetorical sovereignty, as Richard Scotts theorizes, emphasizes on the sovereignty as conceived in the writings of and about the Native Americans in the post-contact period. Not only has rhetoric its roots in oral culture, the strength of the term lies in its ability to transcend oral-written binary. Sovereignty thus has always been rhetorical both in pre-contact America as well as in the traditions where sovereignty is claimed to have emanated from non-rhetorical divine source. 


\section{Chapter 4: Nepali Constitutional Rhetoric: Genre, Authorship, and Sovereignty}

\subsection{Introduction}

Padma Shumsher Rana announced the first written constitution of Nepal in 1948-180 years after King Prithvi Narayan Shan conquered Kathmandu Valley in 1748--setting the stage for modern Nepal. The year 1948 also marked a century since Padma Shumser's predecessor Jung Bahadur Rana took control of the state from the king and started the era of autocratic Rana family regime. Because of opposition within the ruling Rana family, however, the 1948 Constitution never came into effect. Instead, King Tribhuvan ordained a new constitution in 1951 in response to the popular uprising against Rana oligarchy, abrogating not only Padma Shumsher's constitution but also the Rana regime itself. Four more constitutions followed in 1959, 1962, 1990, and 2007, each accompanied by decades of political revolutions, movements, and armed revolts. In September of 2015, the Constituent assembly — the elected body of people's representatives - approved the present constitution. While a tradition for the legitimization and functioning of the government existed in Nepal prior to any written constitution, the adoption of the constitutional genre and its associations with western modernity has had deep transformative implications for the country, starting from the mid-twentieth century.

The constitutional history of Nepal generates interesting questions: What did Padma Shumsher expect the genre of a written constitution to perform for him and the country? Why did Nepal first adopt the genre in 1948 - 132 years after the 1816 treaty of Sugauli largely stabilized the present territory? Why did the 1948 constitution fail, necessitating Nepal to rewrite its constitution multiple times? Why did each of the revolts from 1951 until 2006 make the election 
of a constituent assembly a major demand? Why did the King, who had originally favored such an assembly in 1951, eventually rescind it?

With few exceptions, writers who discuss Nepali constitutions fall into three categories: native Nepali informants writing in English to interested western readers; western writers who present themselves as Nepal experts or consultants on the subject; and activist academics or researchers who analyze the situation and documents with the aim of changing the context itself, largely for further "democratization" of the country. While there is no possibility of any neutral and objective position because of my own inescapable acculturation, this article is an attempt to analyze, conceptualize, and explain the constitutional rhetoric of Nepal without falling into one of these categories by default.

While constitutional forms, historical events, and political concepts serve as the building blocks of this chapter, I approach the constitutional history of Nepal from the perspective of Rhetorical Genre Studies (RGS) as developed in the works of Carolyn Miller, Amy Devitt, David Russel, Charles Bazerman, and Anis Bawarshi, among others. Carolyn Miller's 1984 seminal essay oriented the study of genres away from typified features or forms and toward social and performative functions of a genre. As Devitt summarizes, rhetorical genre studies equips us to see that "genres are created, dynamic, ideological constructs" (348) that perform context-specific functions while remaining partially true to their ideological dispositions generated through earlier practices. Approaching constitutions from the perspective of rhetorical genre studies thus provides us with metaconstitutional insights--the understanding of what and how the adoption of the written constitution transformed the context, the participants and even the genre itself in the process. Metaconstitutional insights are the functions of the written constitution genre that may not have originated from the words used in the document itself but 
by the process of using the genre. It is about the genre's performance in history, thus requiring an analysis of the interplay among the genre, context and participants.

A rhetorical genre studies perspective provides us with the insights that not only enrich but also significantly redefine some of the established views of Nepal's constitutional history and national historiography. For instance, one persistent reigning view has been that Nepal's current state of sovereignty is at a historically low point. A rhetorical genre approach to constitutions allows us to revisit the idea of sovereignty itself as a historically produced discursive formation. Monarchy in Nepal was constitutionalized as soon as the king's power was named in a binding document. That is, the constitution brought the king within the boundaries of formal definitions, allowing the participants to think of alternative possibilities of power, including the abolition of the monarchy. As a result, the question of who gets to write the constitution has shaped the country's protracted, decades-long conflict between traditional and modern forces. ${ }^{63}$

The traditional force-first represented by Ranas in the1948 and then by the king since 1951 - fervently tried to hold onto constitutional authorship because it provided the king a validation of his sovereignty: Declaring constitutions would reinforce the king's traditional status as the law-giver. Modern forces - first represented by the revolutionaries in the 1950 sinternalized an idealized constitutional genre convention from western modernity and demanded the election of constituent assembly to draft a democratic constitution. Cognizant of the constitutional genre and the legitimizing function embedded in it, they insisted on gearing the constitution in their favor-sometimes with the purist desire of following the procedure of

\footnotetext{
${ }^{63}$ See Chauhan for the early characterization of Nepali political actors as modern and traditional. Pashupati Shumshere J. B. Rana complicates Chauhan's characterization as an unrealistic categorization of "the complex politics of an emergent nation" in "the format of a medieval morality plays" (300). Contrary to Chauhan's thesis, Joshi and Rose present king Mahendra's experimentation itself as an attempt to modernize the country.
} 
constitutional authorship from the genre convention as practiced in its ideal setting, while other times avoiding such procedures significantly. For instance, the framers of the 1951 Constitution — given their popular support — could have announced a full-fledged democratic constitution that would have set the history of the country on a dramatically different route. Instead, the alliance of the king and parties chose to declare "The Interim Government Act of Nepal, 1951" because the idealized genre convention that they had internalized required them to elect a constituent assembly to craft a "we the people" kind of popular constitution. The king, who had momentarily committed to the idea of a people-written constitution in 1951, ultimately withdrew the promise, unilaterally announcing new constitutions on his own in 1959 and 1962 with the insistence that constitutional authorship was his prerogative as the sovereign.

The 1990 constitution, drafted after a successful movement to restore multiparty democracy by ending the King's autocratic rule, continued to struggle with questions of constitutional authorship. While the king never publicized his precise views against the popular constitutional authorship (which would have been against the spirit of royal declarations that the Shah dynasty respected the popular will), he fought hard to maintain his own authority within the preamble even when he conceded many of his other powers. His insistence over the content of the preamble suggested that a constitution from the constituent assembly would go against the very spirit of kingship_-besides the loss of power pragmatically for him.

The constitutional history of Nepal is, however, ironic. When the modern forces ultimately found the way to draft their constitution through the Constituent Assembly in 2015, the opposition to the newly promulgated Constitution suggested that the collective authorship crafted through an electoral procedure had become insufficient to fulfill the promise of sovereignty and equality of all citizens. The dissatisfaction with the 2015 constitution reveals 
that the hegemonic procedural aspect engrained in constitutional authorship needed rethinking in the context of postmodern promises of radical democracy.

To understand what and how the adoption of each of Nepal's written constitutions transformed the context, the participants and even the genre itself, the remainder of this chapter will focus on reading each of the preambles. While authorship and sovereignty are at the core of the discussion, they become explicit only in relationship to the contexts of their unfolding. The first section analyzes the context of the 1948 constitution's emergence and Padma Shumsher's use of constitutional genre to legitimize his regime by claiming constitutional authorship. Using critical genre perspective, the section shows how the adoption of the written constitution at that historical juncture was more about the use of the genre's nation-recognizing and regimelegitimizing functions rather than about the rulers' intention to bring about any real political transformation. The second section discusses the 1951 constitution and demonstrates how and why popular constitutional authorship was inserted in Nepali political discourse during the period and how this insertion would drive the rest of the country's history. The third section concentrates on the 1959 and 1962 constitutions, demonstrating how the king bent the genre, especially by claiming that constitutional authorship was his cultural prerogative - a move that used an otherwise anti-hereditary, modern genre for reinscribing traditional practice of sovereignty. The third section discusses the 1990 constitution, claiming how its compromised constitutional authorship derailed the document itself despite many of its promising democratic possibilities. The concluding section sheds some light on the 2015 Constitution, arguing that the opposition to its promulgation was the function of the ambivalence rooted within the genre. 


\subsection{The 1948 Nepali Constitution and the Genre's Nation-recognizing and Regime- legitimizing Functions}

Drawing on Anne Freadman's concept of uptake, Anis Bawarshi has argued that a genre performance accentuates, undermines, and sometimes adds on certain aspects from the standard genre convention. A particular instantiation of genre does not take up all the aspects of a genre in its entirety. Indeed, while the participants using the genre may have an idea of the genre as a stable, fixed form, the genre itself is realized through its performances. The performances can be divergent, although not to the point of being unrecognizable as a part of a species. Written constitution as a genre has certain compelling ideological elements (such as "the consent of the governed") and functional elements (such as the regulation of the government) that originated with the genre's first experimentation in eighteenth-century America. But the way this genre has been taken up globally in the last two centuries, written constitution also has developed new performances that were not the part of, or were only tangentially related to, the American exercise.

As the case of Nepal's 1948 constitution demonstrates, constitution as a genre has generated nation-recognizing and regime-legitimizing functions in its pervasive globalized form by the mid-twentieth century. While never formally colonized, Nepal was caught by the global furor of the mid-twentieth century, when more than $85 \%$ of the world was colonized by the European powers was either already or in the process of being independent. As postcolonial theorists have noted, the independence in that context largely meant becoming a nation-state, an ideological disposition borrowed from modern European tradition, instead of resuscitating precolonial local political structures. While Nepal had enjoyed independence when most of South Asia was colonized, the transformed regional and international context created a new 
historical exigency for the country. Just having a traditional national structure with a few treaties would not suffice the national existence in the new context. Nepal needed to redefine its image if it were to survive the swiftly shifting maps in the region. As the Nepali ruling elites realized by the mid-twentieth century, that would mean adopting the genre of written constitution because the genre was increasingly a defining parameter of a nation-state in a new post-war international order. Not having a constitution could jeopardize international recognition, including the membership in the United Nations.

The historical exigency for the deployment of the written constitution emerged particularly because of Nepal's tenuous national sovereignty, especially in the changing South Asian context. When Padma Shumsher Rana announced the first written constitution in 1948 entitled "The Nepal Government Act," South Asia was going through tremendous political transformation because of the decolonization process. Precolonial boundaries had become dysfunctional, and the independence from British Empire required the region to forge new political maps.

Because of its continued independence, Nepal had well-defined territorial boundaries and a state structure--conditions that spared it the suffering, violence and forced mass-migration that caught most of its southern neighbors in an unprecedented way. But the wave of transformation influenced Nepal in its own way. With the departure of British rulers-Rana regime's strongest foreign ally_-from India, Nepal had lost an anchor in the regional and international order. As many historians have noted, while Nepal's sovereignty was originally won by valor and bravery on the battlefield, Rana regime maintained the official independence in the latter period mostly by supporting the wishes of British Raj — to the extent that Rana Prime Minister had sent his army battalion to suppress an anti-British Indian Rebellion, the Sepoy Mutiny of 1857. 
The provisions of the 1816 Sugauli Treaty between Nepal and the East India Company are testament to Nepal's compromised sovereignty during the period: For instance, the sixth, seventh and eighth points of the treaty brought Nepal under the security umbrella of the Britain Empire. The sixth point of treaty states, "If any difference shall arise between Nepal and Sikkim, it shall be referred to the arbitration of the East India Company." The seventh point states, "The King of Nepal hereby engages never to take or retain in his service any British subject, nor the subject of any European or American State, without the consent of the British Government." Although the treaty was a major milestone that stopped the East India Company from trying to colonize the territories of Nepal to British Empire, the treaty compromised the sovereignty of Nepal until the new treaty was signed between the two countries in 1923. As the new treaty states, it "essentially cancelled, except so far as they may be altered by the present Treaty" the provisions of Sugauli Treaty. With the following words, the new treaty affirmed Nepal's independence: "Nepal and Britain will forever maintain peace and mutual friendship and respect each other's internal and external independence." Given the national glory gained by maintaining political independence when most of the world was colonized, Nepal's current nationalist historiography does not present these treaties in right perspective, often signaling that Nepal's continued political sovereignty fully rested on the country's bravery and power. But the treaties played vital space both in compromising as well as maintaining the country's independence.

Because the country's sovereignty was tenuous during the south Asian decolonization process, Nepal needed a new structure if it were to maintain independence after the departure of the British Raj from India. The chaotic (thus formative) conditions in the region had undermined traditional boundaries, and now the elites in the region-particularly in India — could decide to 
ignore the territorial independence of Nepal. Given Nepal's limited military and economic power in regard to the subcontinent's overwhelming population and land comprised by present-day India, Pakistan, and Bangladesh, Nepal faced an existential threat as a nation-state, at least psychologically. This threat exerts its power even today.

Beyond the regional power dynamics, the international context also shaped Nepali motivation in adopting the country's first written constitution in 1948. After World War II, the whole global context was changing. The newly independent territories in the so-called third world were coming into being as nation-states. With the crumbling of the British Empire, the locus of global power was shifting from Europe to North America. Emerging was the new international order, and institutions of nation-state placed the written constitution at its zenith. ${ }^{64}$ Gone were the days of valor. Technological breakthroughs in the instruments of warfare such as the invention of nuclear bomb meant a massive imbalance among countries' power. Nepal, who could dare to fight the British Empire in 1816, did not have resources for such daring in the new context. For most countries such as Nepal, international recognition (rather than military power) defined their existence as a nation-state.

This regional and global context, coupled with the country's tenuous sovereignty, forced Nepal to revamp its image if it were to preserve its national independence and sovereignty.

\footnotetext{
${ }^{64}$ Critics theorize the post-World War II era of universalized nation-states differently. The revolutionary-nationalist historiography interprets the era as the glorious time of independence and sovereignty. Promoted officially by the states and perpetuated through school curricula, the nationalist historiography presents struggle for independence as a pious and glorious sacrifice made by the leaders and the independence as nation's coming into being, although nativist precolonial "golden age" (mostly imagined and mythical in nature) is often evoked in legitimizing the new nation. This version demonstrates the structural affinity between modern nation-states and the discipline of history as co-enabling and co-informing entities (See Hobsbawm). Some postcolonial critics argue that the colonized locations' birth into nation-states is not so much about newly gained sovereignty as much as it is about the effect of paradigm shift in the structure of western domination from territorial empire to a system of globalization controlled by multinational and transnational corporations (See Dirlik pp.53-76).
} 
Sensing the transformed conditions of nationhood, Nepal, for instance, established diplomatic relationships with the United States and France, and used the relationship as an evidence for securing the membership in the United Nations (Whelpton 69). ${ }^{65}$ Having such recognition at an international forum would make Nepal stronger in the region. As Bazerman has noted, genres work in a system by reinforcing each other's functions. In this context, when Nepal was searching for and deploying the nation-recognizing genres approved by the international community, a written constitution automatically served the need along with other genres such as treaties that established diplomatic relationship between countries. It is important to note that in this context it did not matter much at the international level whether a constitution was proposed, drafted, and ratified by an appropriate body; that a country had a written constitution was the evidence of nationhood in the new dominant global political cultural imagination.

Besides this nation-recognizing function, Padma Shumsher also sensed a regime legitimizing function in the constitutional genre. Not only did the British departure from the subcontinent require the realignment of international politics for Nepal, the struggle for and winning of independence in India in the 1940s had its own political reverberation: Gandhi's catch phrase "self-rule" - used to mobilize a large swath of people in a diverse linguistic and cultural setting—-held deep democratic, economic and even spiritual meanings. "Self-rule" coalesced a complex set of ideas from diverse sources such as traditional religious beliefs, British legal theories, and Thoreau's and Tolstoy's economic-spiritual view. The ideas of democracy and self-rule resonated deeply with Nepali revolutionaries. By establishing political parties and waging revolution for democracy, they wanted to use the transformed international context in their favor. For them, the Rana regime had become a vestige of the past, unsuitable to

${ }^{65}$ Other evidences included Nepal's formal treaties with Tibet and the United Kingdom. 
meet the democratic aspirations of the nation. The protest across the country created an exigency for the ruling Ranas themselves. Their traditional style of politics had started to become infective; they needed to fight back by using the same ideological weapons of modernity. If the people wanted a legitimate political system appropriate for the new age, the Ranas had to prove that they themselves were that system. A written constitution, along with other reform programs, helped legitimize their regime.

Textually, this sensitivity to self-legitimization is particularly evident in the preamble of the 1948 constitution. It reads,

Whereas, by virtue of the Supreme Power vested through the instruments of their sacred Panja-patras by Shree Panch Maharajadhiraja of Nepal, dating from the year of 1903 BS onward, delegating all powers of the State upon the contemporaneous Shree 3 Maharajas, whereas it is our fevent desire, through all social, economic and political developments to bring Nepal, this sacred country of Lord Pashupatinath, in line with the advanced nation of the world and grant our beloved motherland her rightful place in the comity of nations. (From the Preamble, “Government of Nepal Act, 2004 [BS]").

The preamble casts the Rana regime and the new constitution in legalistic fashion. By quoting, the "scared Panja-patras" (royal seal; literally, the papers stamped with the king's hands) as the source of his power twice in the preamble, Padma Shamsher accentuates the idea that the country had the legal apparatus even before the drafting of the first written constitution. While the nation might not have had a written constitution in the past, it did have traditions that were as significant and binding as the constitutional provisions; thus, the royal seal still mattered and was binding to all stakeholders, including the king. Questioning the legitimacy of the Rana regime 
thus was to interrogate the foundational state structure of the nation itself. Protecting Nepali identity required respecting the state and its legal traditions.

But what this claim of Nepali identity missed is that revolutionaries had internalized the function of a written constitution differently. Influenced by western and Indian experimentations, their foremost focus was on popular authorship. Many of the revolutionary leaders had seen the elections for a Constituent Assembly in India in 1946 and the subsequent drafting and promulgation of the Indian Constitution. ${ }^{66}$ From their perspective, Padma Shumsher or even the king could not be the legitimate author of the constitution. Padma Shamsher, who is often cast as a reformist in Nepali history, had anticipated this opposition, and the constitution therefore included many reforming programs, including the provision for fundamental human rights, and a form of elected legislature. The revolutionaries nonetheless rejected the constitution on ideological grounds: they were fighting for democracy, which would be realized only upon the promulgation of a people-written constitution. For them, abolishing the Rana regime and forming a civilian government were merely the necessary conditions for democracy. The sufficient condition — which was inspired by the idealistic democratic practices in western countriesentailed a people-written constitution with fundamental rights and democratic principles.

This contestation regarding the procedure, place, and function of the 1948 Nepali written constitution provides us with new insights about both genres in general and the constitution as a genre. When we think about genres, we expect them to perform relatively uniformly at least in the same context because genres in the practical world are normally settled phenomena without inviting substantial discussion on their very nature. For instance, people may discuss the content of a letter but rarely the nature of the letter as a genre itself. That happens largely because the

66 The Indian Constituent Assembly was indirectly elected by provincial legislatures. 
letter in that context is a settled entity, without requiring further qualification. Mostly, it is only in academic settings that established genres such as letter and reports are unfurled for analysis as teaching and research tools. The debates surrounding the 1948 Nepali constitution suggest that even in the practical world, genres themselves can generate discussions if they are not wellestablished among the participants. Certainly, Nepal appropriated the genre of written constitution for its nation-recognizing and regime-legitimizing functions. Yet, since the participants in the context of 1948 Nepal did not have a tacitly agreed understanding of a constitution, they discussed the genre of the constitution itself by referring to various foreign experimentations. As Devitt emphasizes, "genres do not exist independent of people, though the generic actions of some people influence the actions of other people. To say that genre is a social action is to say that people take action through their conceptions of genres" (50). If a genre is a foreign entity trying to settle in a new situation, appropriating parties try to familiarize it before letting it settle in their terms. The Nepali experience with the 1948 constitution was an attempt to familiarize itself with the new genre-knowing what it was and appropriating it for the cause of sovereignty.

\subsection{The 1951 Constitution and the Question of the Genre's Collective Authorship}

The 1948 Constitution also prompted discussion of sovereignty with different views to constitutional authorship. Ranas insisted on the doctrine of a monarch's divine sovereignty, claiming that the sovereignty rested in the king. The claim allowed Padma Shamsher to author the national constitution on the proposition that the king had delegated his sovereignty to the Rana prime minister's predecessor. But revolutionaries rejected this idea because they had imbibed the new notion of sovereignty with the stipulation that the people were the rightful authority to write their constitution, a notion evolved and expanded with modernity. Caught in 
this conflict, the 1948 constitution could not come into effect at all. Eventually, the revolutionaries and king Tribhuwan forged a coalition against the Rana regime, successfully ending Rana rule. The nation had entered into a new phase: Now not only the country needed a written constitution, ${ }^{67}$ it required to observe popular sovereignty in the constitutional authorship if it were to be a democratic modern nation.

This was a unique historical moment capturing the country's transformation from traditional to modern statehood. Nepal might have emerged organically earlier claiming an irresistible unique identity in the region, but now it had to imitate the image of the modern nation-state in order to be relevant in the new situation. The imitation promised not only external recognition for the country, but also the internal devolution of power from the handful of families to the great mass of people. As the preamble of the 1948 constitution accentuated, the imitation would mean bridging the old nation with the new democratic polity. Indeed, this imitation was directly about the people's democratic rights and responsibilities, but even more important was the promise of general peace, prosperity and happiness embodied in those ideals.

Undoubtedly, the 1950s did not see a complete break in the psychosocial disposition of an individual person from the past, and certainly variables of one's existence such as class, education, gender, geographical location, caste, and ethnicity structured each person differently, but the macro-modification in the image of nationhood accompanied a new conception of personhood as well. The transformation involved a new conception of individual, including what one should expect from life, what it means to live a successful and happy life, and how the state can be helpful in realizing individual aspirations. Until this moment, the state from the people's perspective was largely a regulating body, punishing transgressions and ensuring basic security;

\footnotetext{
${ }^{67}$ This was an important development because the country had been operating without a written constitution until that point.
} 
it was basically a law and order project. After all, the Civil Code was the governing document of the time. The state in pre-constitutional time in Nepal was not conceived as a grand project designed for the wellbeing of its people. The discourse of development, democracy and success as envisioned in secular modernity and accompanying capitalism had not yet become a major part of Nepali consciousness. Thus, the adoption of the constitution was a part of a massive psycho-social modification in the conceptions of an individual, state, and life.

Although the written constitution was the most critical genre bridging this transformation, Nepal's adoption of the genre did not come smoothly. In the absence of the country's long history with the genre, again the mode was mimetic; the country looked to its surrounding for cues and expert advice for drafting its new constitution. Genre theorists such as Devitt and Bazerman have emphasized the role of context and learning in the way participants use a genre. Nepali users of the genre observed the region, thought about their own national history, and tried to find the best course available for them. The king and the revolutionaries were in a position to announce a full-fledged democratic constitution in the name of the people. Instead, they announced, "the Interim Government of Nepal Act, 1951" qualifying it as an interim act, and postponing the installation of a full-fledged constitution until the formation of a constituent assembly, although the act did not include a specific date for the elections of such body. Influenced by Indian and American constitutional practices, they thought that proper popular authorship rested at the core of the written constitution genre.

From a genre perspective, however, the 1951 Nepali constitution was a compromised public action: It promised a people-written constitution yet did not even offer a full constitution for the moment. The compromise largely was the function of the conflict between the dominant socio-economic condition and the idealistic affective mood of the time. Interpreted from a 
Marxist perspective, the material base, particularly the feudal socio-economic condition led by the king and Ranas, did not support an immediate election of a constituent assembly. But the idealistic political aspirations that resulted from the revolution would not settle for anything less than a people-written constitution. With the success of the revolution, the king, who had been relegated to a titular head bereft of any executive power for more than a century, regained his centrality in the nation's polity. For political parties, the doors of opportunity had opened suddenly. Emotionally, the moment was optimistic. Even the king had internalized an idealistic vision of constitutional authorship at the moment (something that he would disavow later). While the socioeconomic base was stopping the decision for a constituent assembly, the widely shared mood was prompting them to look for something to transcend the constraints.

What this conflicting 1951 Nepali context suggests is that particular uptake of a genre is not always determined by one factor. Context is complex and often full of contradictory impulses. The uptake of a genre such as a national constitution, which demands the public performance of a large body of forces, tries to pull genre in different directions. Given that Nepal's constitutional history at this point was almost non-existent, the king and the revolutionaries did not have a native tradition to follow or a hardened belief about a constitution. ${ }^{68}$ Charles Bazerman writes, "We learn about what to expect from genre through public and personal histories of experience with them (Bazerman, Rhetoric 30). The Nepali actors in 1951 were guided mainly by an abstract idealistic foreign tradition that resonated with the upbeat pathos following the success of the revolution. Thus, instead of pragmatically securing the political achievements of the time in a constitution by establishing a functioning democracy, they looked for the procedural purity of constitutional authorship. What they forgot

\footnotetext{
${ }^{68}$ For the brief political history of Nepal from the perspective of democratic transition, see Parajulee 25-65.
} 
in the process was that the content of the constitution written by a constituent assembly does not necessarily have to be more democratic than that of a constitution drafted by other processes. For the young revolutionaries ${ }^{69}$ who had unseated the autocratic family regime that had reigned for more than a century, the significance of a proper constitutional authorship for a democratic polity was a non-sacrificial substance at that point. $^{70}$

Unfortunately, by opting for a momentary compromise, the Nepali leaders of 1951 created a philosophically incoherent constitution. Textually speaking, the result was the gap between the spirit of the preamble and the absolute power ascribed to the king in the constitution. The 1951 preamble embodied the democratic principles in simple language. ${ }^{71}$ King Tribhuwan “ordained and promulgated ...the Interim Government of Nepal Act, 1951" on "the advice of the Council of Ministers" because "it is necessary till such time, as the Constitution is not framed and promulgated, the administration of the country should function according to a Constitution and certain rules and principles" (from the preamble of the 1951 Constitution). Hard laws had ruled general populace for a long time, but now with this preamble, the government also came within the province of law-a big leap. But the provisions within the constitution did not reflect the preamble's democratic spirit. Certainly, the constitution included a long list of rights, something that had come from the Anglo-American bill of rights tradition that the departing British rulers in the region were insisting to adopt for the newly independent countries largely to safeguard minorities from majoritarian government. ${ }^{72}$ Practically, the constitution reinstated the absolute monarchy, ascribing total state power to the king, giving him freehand in appointing

\footnotetext{
${ }^{69}$ B.P. Koirala, who led the Congress Party in the new cabinet, was 36.

${ }^{70}$ See the 1949 Nepali Congress Manifesto.

${ }^{71}$ As the preambles of Nepali constitutions demonstrate, language gets to be complex and complicated when the ideas expressed are contentious, needing strong justification that tends to make the argument convoluted.

${ }^{72}$ See Parkinson 36-54.
} 
minsters, judges and officials in other branches of the government.

How did this discrepancy become acceptable for the political parties that had waged the revolution to establish a constitutional democracy? Again, we need to think of the context to understand the participants' motivation. Two factors generated this inconsistency. First, even with the imperfect constitution, the revolutionaries believed that the country had entered into a constitutional phase. The statement in the preamble that "the administration of the country should function according to a Constitution and certain rules and principles" bore transformative political possibilities. From political parties' perspective, gone were the days of a ruler's whimsical arbitrary dictates; written laws would determine even the king's power. Even when the new constitution privileged the will of the king momentarily as the rule of law, having that point written down in the constitution meant that the nature of politics had dramatically shifted. Second, the revolutionaries trusted the king's ethos (naïve from the present perspective) because he had sided with them in the revolution. Despite the intricate blood relationship with the Ranas because of interfamilial marriages, the king had abdicated the throne in protest, dramatically enhancing the credibility of the revolution. The conspiracies and whims that plagued the royal palace ultimately giving way to the rise of Rana regime was merely a lore of the past, not even a distant memory for this generation fighting for democracy. And, indeed, the fact that the king's ancestor had led the country's unification bestowed on the nation a distinct identity that automatically added value in the way the revolutionaries perceived the king's ethos. The crown was the sign of the country's continued independence, a condition that freed the country from having to establish a legitimate constitutional authority immediately, unlike the postindependence contexts of the United States of America or India. They could just use his traditional power to ordain laws for the interim period until the pragmatics of holding elections 
for a constituent assembly were established. Given that the Ranas were still powerful (the first prime minister under the 1951 Constitution was Mohan Shumsher Jung Bahadur Rana), entrusting the king with state power through a constitution for the interim period until the election of the constituent assembly made a pragmatically expedient decision as well.

In the way subsequent history unfolded - particularly the fact that the king withdrew the 1951 Constitution's promise of a constitution written by an elected body by repeatedly announcing new constitutions himself - it can be said that the revolutionaries' desire to follow the electoral procedure to craft popular authorship turned out to be ironic; their desire for an ideal constitution made them lose what they could have achieved without following the route of a constituent assembly. Had they pushed for drafting a democratic constitution without according the king the absolute power or making the 1951 constitution a constitution-in-progress, the nation would certainly have taken a different course. This assessment may sound completely speculative, but it is important because it tells about the fault lines of observing the idealistic genre convention of the constitution without fully observing the context for that approach. Something thought to be idealistic could turn into a self-limiting prospect.

Eventually, the king crushed the revolutionaries' naïve idealism and trust as expressed in the preamble. Increasingly, the provisions of the constitution that accorded the absolute power to the king started assuming full force. As the events between 1951 and 1959 demonstrated, the king stalled the election of the constituent assembly indefinitely. In the absence of a definite deadline for the formation of the constituent assembly, the revolutionaries' only hope rested on the king's conscience. Had there been a provision of judiciary interpretation of the constitution or a tradition of independent judiciary to that effect, the spirit of the preamble might have exerted some influence. In the absence of such a condition and the king's disloyal conduct, the words of 
the preamble remained ineffective. In the culture where the king held deep-rooted authority and society was habituated to an autocratic rule, the king's absolute power, rather than the preamble's promise of democracy, came naturally. To sum up, the power granted by the genre of the constitution and the power descended from the tradition mutually strengthened each other to create an absolute monarch in practice, crushing the democratic will deposited in the preamble.

With the introduction of the written constitution, Nepal witnessed the emergence of a liminal space in the practices of sovereignty. On the one hand, the introduction started new tradition of sovereignty, the practice of the rule of law as written down in the constitution, statutes and civil codes. The introduction promised the notion that national politics and power would be mobilized in accordance to the words in the constitution. But, on the other hand, the king's assumption of the constitutional authorship along with his absolute power reinforced his traditional sovereignty. So, while the country was trying to learn to operate according to the words of the constitution, a collective national feeling persisted that traditional king could jump into scenario any moment stopping the march of modernity. Unlike in the Unites States, where all political crises have to be solved using the words of the constitution and related statues, the presence of the king undermined the constitution-based practices of sovereignty in the early constitutional period of Nepal. This lead to a hybrid form of sovereignty in which the written words of modernity as well as the unwritten forces of tradition mixed together forming different matrixes between them-sometimes colliding intensely while cooperating smoothly in other times.

\subsection{The 1959 Constitution and the King's Claim of Constitutional Authorship}

In 1959 King Mahendra announced a new constitution that formally rescinded the people-written constitution promised by the 1951 constitution. With the stroke of his pen, the 
king proclaimed "an efficient monarchial form of government responsive to the wishes of the people" (Preamble, 1959 Nepal Constitution). ${ }^{73}$ Even though the1951 constitution provided for an absolute monarchy, its spirit was not monarchist: the king had ordained and enforced it, but he did not hold the sole authorship as the 1951 constitution was an agreed-upon-document among the major contemporary stakeholders. The 1951 document was, however, merely an act, designed for an interim period. By 1959, the king needed a more stable and prestigious constitution to cement his recently revived and solidified power. He could do so only by claiming the total authority over the constitutional authorship: thus although he conceded some of his power with the provision of popularly elected government in the 1959 constitution, he claimed full authorship of the new constitution, something that was not there in the 1948 and 1951 constitutions.

But the king's claim to constitutional authorship was not a smooth sail. During the last two decades preceding the announcement of the new constitution, two views on constitutional authorship were gaining prominence in the Nepali public sphere. On the one hand, political parties had further augmented the idea of a constitution authored by the people. On the other hand, the king was reviving the traditional cultural epistemologies that accorded the power of authoring law to the monarch. From the political parties' perspective, constitution as a genre was a vehicle of modernity. A national constitution needed to follow an internationally-established, deliberate, rational procedure for it to be a legitimate governing document. But monarchists, who had recently consolidated state power, tried to present the written constitution merely as a new tool within the traditional cultural framework. While not so clearly articulated, these two visions

${ }^{73}$ On March 16, 1958, King Mahendra formed a commission to draft the 1959 Constitution. Led by Chairperson Bhagawati Prasad Singh, the commission included Surya Prasad Upadhya, Ranadhir Subba and Hari Prasad Joshi as members. The king also invited British constitutionalist Sir Ivor Jennings to advise the commission. 
of constitution circulated in the public sphere, resisting the king's effort to own the constitutional authorship fully without opposition. The country already had a written constitution from 1951 that theorized constitutional authorship against the monarchist interpretation. That fact created an extra burden on the king, making his assumption of constitutional authorship a reactionary move. $^{74}$

In a sense, the king's assumption of the authorship in the context of 1959 Nepal bended the spirit of the constitutional genre. As stated earlier, the 1951 constitutional Act had already defined the parameters of constitutional authorship. The king successfully made a powerful rhetorical move to claim that constitutional authorship was his prerogative. Among many strategies, one of his prominent moves was to insert the mythologized cultural view of monarchy in the new constitution. Here is the first clause of the preamble, although the English translation does not fully capture the spirit of the Nepali text:

Whereas His late majesty King Tribhuvan Bir Bikram Shah Dev, Father of the Nation and revered descent of the illustrious King Prithvi Narayan Shah, adherent of Aryan Culture and Hindu religion, having led a Great revolution for the rights and welfare of His subject, earned immortal fame in the history of the world and was firmly resolved to establish real democracy in Nepal by giving fundamental rights to the people.

It is important to note that in the original Nepali text where the constitution was promulgated, this clause is preceded by another paragraph. The excluded paragraph, which is difficult to translate into English because of the absence of similar concepts in the target language, may not

\footnotetext{
${ }^{74}$ Nepali Congress and its allies organized Civil Disobedience Movement in 1957 demanding an elected government as promised in the 1951 Constitution. The movement was called off after an agreement with the king to hold an election for the parliament.
} 
have significant information but plays a powerful cultural role in establishing the tone for the cultural supremacy of the king, even suggesting the king's entitlement in authoring a constitutional document. The untranslated paragraph is a customary paean that celebrates the glory of the king, includes his titles, and wishes for his perpetual victory. The excluded text came from a long tradition of chanting a formulaic paean celebrating the greatness and glory of the king at the beginning of the royal ceremonies. Ingrained in the practice, the chanting associated the king with a non-earthly power, by placing him in a divine realm.

The non-translated paragraph, along with the clause cited above, is the first of its kind in the constitutional history of Nepal that would set the tone of politics at least for the next half century. The text did not only elevate the Shah dynasty but also defined the culture of the nation. In the process, it executed many goals simultaneously: Foremost, it constitutionally catapulted the Shah king to the center of national identity and discourse. Undoubtedly, the Shah king had been at the center of the Nepali state from the beginning of the unification process. And, indeed, the 1948 constitution also reinforced that centrality even when the king did not hold the executive power; and, as explained earlier, the 1951 constitution accorded the absolute power to the king. But this preamble was unique in the sense that the king's cultural sovereignty was brought into the constitutional realm, a transference that helped the king strengthen his power as the constitutional author. Undoubtedly, Nepali cultural landscape before this period. The centrality of the monarch in the cultural life of the nation came from the mythical and religious stories such as Mahabharata and Ramayana. Thus, while the Nepali kingdom was established with hard fought real-world efforts in which many chieftains and kings from small mediaeval principalities perished and the Shah dynasty prevailed, the best resources for understanding the place of the monarch emanated from mythical-religious world view. It is this cultural worldview 
that did not allow Ranas to abolish monarchy, despite their absolute power during the Rana period. The cultural imagination required a legitimate king; no matter how powerful the Rana ruler was, the king's cultural capital overwhelmed the Rana's worldly power. During the period, while a not-so-subtle imitation of British royalty in language and practices would also begin, the kings tried to cast themselves in the image of the mythical monarchs.

While further historical research can narrate the full process and history of the mythologization of the Shah Dynasty in detail, merely the analysis of the names of the successive kings from Prithvi Narayan Shah to Mahendra Bir Bikram Shah Dev illustrates the shift of the Shah Dynasty from a small feudal chieftain to the kingship aimed at religio-mythical level with divine authority. The name Prithvi Narayan Shah (January 11, 1723—January 11, 1775) does not claim any higher mythical or religious place; it can be any commoner's name. Nor do the names of his early successors_-Pratap Singh Shah (16 April 1751—17 November 1777), Rana Bahadur Shah (May 25, 1775-April 25, 1806), and Girvan Yuddha Bikram Shah (October 19, 1797-November 20, 1816) suggest any association with divinity. These names rather valued the valor and bravery-important attributes in the context of the ongoing "unification" process started by Prithvi Narayan Shah that was not complete until the 1816 Sugauli Treaty with British government. Since the power of the king during this period came more from his ability to organize wars and execute them successfully, the mythologization of any sort that we encounter in the later period did not make much sense. The mythologization of the names of the kings began after the stabilization of territorial boundaries and the ascendency of Rana Regime. As court intrigues and a consolidation of power became the dominant mode of politics, the mythologization of monarchy served the cause. Instead of valuing the king for his valor in the war or even his administrative skills, the mythologization gave the kings a sense of 
cultural superiority - a divinity without any direct consequence — and helped legitimize the Rana Regime that technically executed power as the delegate of the King. As a result of multigeneration mythologization, the humble Prithvi Narayan Shah metamorphosed into Mahendra Bir Bikram Shah Dev: the number of words in the name increased, and the new words such as Mahendra (Maha+ Indra: Indra in Hindu mythology is the god of heaven and Maha translates to "great") and Deva (God—common name) added an aura of divinity to the traditional character of bravery and valor represented by words such as Bir and Bikram.

This whole discussion of the mythologization is warranted here because the preamble, particularly the excluded text from the English translation, was the summative point of the process. By including the mythologized version of the monarchy in the constitutional text, the king suggested that the adoption of a new genre of legitimization was not the beginning of a new kind of politics, but a continuation of the same old order in a slightly different form. The mythologized version of the monarchy preamble was used to establish the ethos of the king, an attribute not grounded on the direct achievement of the person holding the throne but emanated from the dynasty's illustrious past and its association with divinity. Such glorification of monarchy answered the critical question of authorship that had a pressing presence in the constitutional rhetoric of Nepal from the time of the promulgation of the first constitution. Since the 1951 constitution expected the elected representatives of the people to write the new constitution, the king needed to justify his new iteration in 1959. The glorified mythologization of the Shah dynasty in the preamble established the king's rationale for the claim of authorship of the new constitution. From this logic, the king was the glorious sovereign born to give laws.

By the 1950s, however, this mythic-religious worldview was losing its power as the alternative forms of political imagination had entered Nepali cultural discourse with people's 
intensified interaction with the outside world. A large section of the Nepali population had returned from their service in World War II hardened for political fights and exposed to ideas of modernity such as democracy, communism, and capitalism and their counterparts such as fascism, autocracy, and feudalism. The recent political experimentation of India, led by British educated lawyers such as Mahatma Gandhi and Jawaharlal Nehru (in which many first generation modern Nepali leaders had participated), created an active political class in Nepal that interpreted political economy using the vocabulary of contemporary western political and legal discourse. Within the country, the vibrant discourse of political philosophies during the decadelong transition from 1951 to 1959 gave emergence to many political parties expanding their reach beyond India-educated or influenced individuals. These factors challenged the traditional cultural view of politics, particularly the centrality of monarchy in politics.

Now, if monarchy were to be legitimately sustained, it needed supplementary justification in modern discourse..$^{75}$ The king perceived that the genre of the constitution was the surest means of such justification in the modern time. He did this first by further accentuating the mythic-religious cultural imagination by casting the king as an "adherent of Aryan Culture and Hindu Religion." Subtly inserted into this casting was the mythologization of his father King Tribhuvan and his ancestor Prithvi Narayan Shah: by characterizing Prithvi Narayan Shah as “illustrious" founder and King Tribhuvan as "revered" and "Father of the Nation," who “establish[ed] real democracy in Nepal by giving fundamental rights to the people," the preamble

75 Though formulated after six years, the preamble of the $1^{\text {st }}$ amendment of the Muluki Ain (General Code) captured the changing context succinctly: "Whereas, it is not possible to deal with all transactions only thorough religious literatures (Shastra) over the course of time, and alterations and amendments have been made, to the tune of the country, time and circumstance, from time to time, to Muluki Ain (General Code)." While the constitutions do not explicitly express it the way the General Code does as the king was fighting back the currents of changing circumstances, the quoted lines clearly represent the understanding of the increasing inadequacy of religious-mythical worldview and growing secularization. 
not only used familial images to establish the place of the monarchy in the new cultural imagination but also hinted at the mythical kings such as Ram, Krishna, and Janak who fight for the shake of Dharma (righteousness), Naeya (justice), and Kalaena( well-being) of his people. For Nepali readers who had grown up with the Shah-Dynasty-centered Nationalist historiography and narratives, these appellations may sound a natural, appropriate interpretation of history. Given the centrality of the kings in the national history, including in the formation of the nation itself, the historiography made sense. This "natural" appearing historiography began as a discursive formation with the 1959 Constitution and intensified during the Panchayat period following the enactment of the 1962 Constitution. The 1959 and 1962 Constitutions reinvented, re-conceptualized, and repurposed the institution of monarchy by strategically deploying the constitutions themselves and related genres. The reconceptualization of the monarchy used mythical monarchical patterns, British tradition and other regional and global paraphernalia of modern nation-state. For instance, think of how King Tribhuwan was cast as "father of the nation" in the fashion Gandhi was called so in India. Such reinvention in the post-1948 period helped the monarchy gain political currency in the new cultural politics formed around ideas such as constitutions, democracy and development. In a sense, the preamble was an ironic climax of the mythologization of Nepali monarchy that used an otherwise ideologically antihereditary and anti-feudal modern genre of political legitimation to establish a monarchical form of government.

While it was a powerful move that epideictically exploited the country's dominant belief system, the production of the king's ethos in mythologized terms alone was not sufficient to bend the constitutional genre convention. As the 1959 preamble stands, the king understood this, and 
thus felt the need to further emphasize his authority to author a constitution. Here is the clause in the preamble for that effect:

I, King Mahendra Bir Bikram Shah Dev in the exercise of the sovereign powers of the kingdom of Nepal and the prerogatives vesting in US in accordance with the traditions and customs of our country and which devolved on us from Our August and Respected forefathers, do hereby enact and promulgate this fundamental law entitled "The Constitution of Nepal."

Expecting opposition, the statement presents a forceful justification to the king's claim to legitimate constitutional authorship. This sentence is not a normal, routine statement as expected by the public from the traditional monarchial perspective. A sovereign ordains a law without justifying his or her power to proclaim it. Such authority is assumed to be given, without requiring explanation. The perceived need on the part of the drafters to include the justificatory statement suggested that the king had lost the self-sufficiency and sovereignty expected in a traditional monarch-forcing him to legitimize his authority by referencing custom and process. Thus, while King Mahendra had custom, tradition and power on his side, the extended justification suggests contextual tensions, particularly the prevalence of voices against the king's claim to constitutional authorship.

If observed closely, something fundamental had changed in Nepal regarding the nature of power through this preamble. Traditionally, the state power was conceived as something possessed by the king. But the preamble unwittingly established the idea of the transferability of power from one body to another-an important epistemological transformation in Nepali political-cultural landscape of the time. For instance, as explained above, the whole mythologization of the monarchy tried to ascribe complete sovereignty to the embodied king. 
Everybody knew about the tradition of primogeniture royal succession; while the public needed to be informed about the transfer of power, the palace itself traditionally hinted that what happened within the royal family was not of much public concern. Engaging the public about the line of succession, how the current king's power had devolved from his ancestors, the preamble brought the source of the king's power into direct public discourse. The approach is contrary to the subtle mythologization strategy applied in the first part of the preamble. With the discussion of the king's succession history, the constitution made an epistemological modification in the way kingship was conceptualized in Nepal: Instead of understanding the power of the king as something embodied in his personhood that made him the self-sufficient sovereign during that moment, the statement interpreted the king's sovereignty as something that had devolved from one person to the other. Indeed, in the context of the Constitution, the power delegated from his ancestors to king Mahendra, but it also established the notion of the transference of power, an idea that power can move from one body to the other.

Two factors contributed to such transformation. First, it was the function of the genre of the constitution itself. Ideologically, a written constitution as a genre demanded a clear description and demarcation of power. Born with the republican aspiration to make power accountable in eighteenth-century America, a written constitution logically expected the elucidation of the source and description of power, including the king's authority to author the constitution. From that perspective, it was not only the king who was performing social actions using the genre, but the genre itself was performing certain actions, structuring participants' expectations and ideas about power in a certain way. This leads us to the second factor: the context-driven functions of genre.

In 1959, the contextual first challenge came from the genre convention itself: As 
experimented in the American context and internalized in Nepal, only people could be the legitimate author for the constitution; the whole idea of constitutionalism, democracy and modern statehood revolved around the popular constitutional authorship. Second, the 1951 promise had its own moral pressure. And, third, political parties themselves were challenging the king's rule and authority to write a constitution. This context warranted a place in the preamble for the king's justification of his constitutional authorship. But ironically, a justificatory statement in the constitution also automatically opened the space for counter-arguments by political parties, again intensifying the idea that the king had misused the genre without respecting its core values.

If the 1959 constitution was a regressive move as it stalled the promise of a peoplewritten constitution enshrined in the 1951 constitution, then the question becomes, how did the political parties agree on the constitution? First, as the history suggests, political parties had lost much of their influence during the preceding decade because of the king's use of absolute power, particularly by playing within political parties with his strategic appointments. The frequent changes in the government led the country through a treacherous transition and instability that demoralized political parties. The Nepali Congress was looking for an opening as their demand for a constituent assembly was almost dashed. In this politico-psychological context, the king commissioned British constitutionalist Sir Ivor Jennings to draft the 1959 constitution, and Jennings used the Westminster system, although heavily departing from the model by providing unlimited power to the king, including his ability to suspend the constitution. ${ }^{76}$ But because the constitution arranged for a provision of a popularly elected government, it opened an opportunity for democratic participation by political parties despite their crushed dream of a people-written

${ }^{76}$ See Malagodi 151 (2016). 
constitution. Using this arrangement, the first ever general elections were held in 1960, which resulted in the Nepali Congress's first popularly-elected two-thirds majority government led by charismatic B. P. Koirala.

While the 1959 constitution upheld democratic Westminster form, an analysis from the perspective of authorship shows that the constitution functionally established the king's sovereignty, not only by stating it literally and by making him announce the constitution but also by placing him above the daily governmental administration. The constitution envisioned the king's place in a kind of godly way as somebody who was above the fray of daily, immanent activities and with the ultimate power to suspend his own laws. This arrangement could not last long. As with the case of the 1951 constitution, the discrepancy between the spirit of the preamble and the articles started to exert its force_-pitting the king against the popularly elected government. ${ }^{77}$

The constitution had vested unlimited power to the king, but it also had the provision of an elected government to run daily administration. Following the 1960 elections, B.P. Koirala formed his cabinet and started to introduce reform programs, assuming he had secured the mandate for such actions. Simultaneously, the country's political culture also was changing in practice. Because of the 1959 constitution, politicians did not have to fawn upon the king to win political appointments. A party could form on the basis of its electoral success. As the constitution came into operation displaying this transformed political landscape, the king found that the sovereignty vested to him was merely abstract and ineffective. Indeed, he could visualize the danger of losing even that abstract power if the democratic process continued. The king used

${ }^{77}$ See Chauhan, R.S. The Political Development in Nepal, 1950-70: Conflict between Tradition and Modernity. New York: Barnes and Noble, 1972. 
the emergency provisions in the 1959 constitution to sack the government and place the prime minister and his supporters behind the bars. In the process of resuming the state power, he abrogated 1959 constitution and authored a new constitution in 1962, introducing an autocratic, party-less, monarchial system that would last for the next thirty years.

\subsection{The 1962 Constitution and the King as Constitutional Law}

In the period between dissolving the Koirala government and the promulgation of 1962 Constitution, the king had certainly consolidated the power and established an absolute monarchial system, but again he felt the need to justify not only his actions but also his claim to authorship of the constitution. He wanted to make sure that his sovereignty and the provisions in the new 1962 constitution did not bifurcate in spirit and practice. The preamble of the 1962 constitution again served as the site of such justification. In the preamble, the king felt the need to highlight "the constitutional law" as one of the sources of his power to promulgate the new Constitution:

Now, Therefore, I, King Mahendra Bir Bikram Shah Deva, in exercise of the sovereign powers and prerogatives inherent in us according to the constitutional law, custom, and usage of our country as handed down to us by our august and revered forefathers, do hereby enact and promulgate this Constitution. (Preamble, 1962 Nepal Constitution)

While this preamble may resemble the spirit of the preamble of the 1959 Constitution in terms of the king's advocacy of his distinctive hereditary and customary prerogatives, it is comparable to Padma Shamsher's 1948 Constitution in terms of the announcer's source of legitimacy to the constitutional authorship. Padma Shamsher referred to the Royal seal (Panja-Pantras) as the source of his power for his constitutional authorship. In the similar fashion, the king reminded 
"the constitutional law" for claiming his authority to enact the new constitution, thus conceding that "custom, and the usage of our country as handed down to us" of the 1959 constitution had become insufficient for the king's assumption of constitutional authorship in 1962. The words "the constitutional law" in the 1962 preamble — no matter how abstract and vague — served the purpose in that context: Referring to the master tropes of modernity and legitimizing genre convention of standard nation-states, the king made the act of enforcing new constitution a legalistically valid exercise that could be justified in light of the spirit of the previous constitutions. Certainly, by not referencing the action to any particular article with the sweeping claim, the king also made it difficult for the dissenters to oppose his move with a concrete constitutional reference. In a sense, he himself had become the amorphous, abstract "constitutional law" in the process.

The justification for the move of both sacking the popularly elected government and declaring a new constitution went even beyond the preamble's abstract reference to the “constitutional law." Article 2 of the 1962 constitution, after defining the nation as an entity "having common aspirations and united by the common bond of allegiance to the Crown" (Article 2:1), states, "It is indefeasible and Inalienable right of the Nation to develop its political, economic and cultural life and to determine its relations with other nations, in accordance to its own genius and traditions" (Article 2.1, the Constitution of Nepal, 1962). If we think of a nation's constitution as the supreme law of the land, this statement is irrelevant because it speaks more to the audience outside the nation (now, defined in terms of "united by the common bond of allegiance to the Crown") to whom the constitution is nonbinding. If read closely, the statement's intertextual connection with the 1776 American Declaration of Independence is unmistakable. It reinforces a nation's natural right to determine its own course. Undoubtedly, 
Nepal was not declaring an independence from any country at that point: Why did the drafters include this statement?

As the next thirty years' experimentation with the king's direct rule would show, the statement represented a declaration of independence from the democratic process that had begun with the 1951 constitution. The new constitution derailed the democratic process completely and started a nativist political system called Panchayat. The king's strategists used the adjectives such as 'native' and 'soil-suitable' to brand the new system and marketed it effectively by comfortably contrasting it from the 'foreign' and 'non-national' systems that their opponents supported. The system itself was borrowed from autocratic constitutional model dubbed as guided democracy and practiced in countries such as Pakistan and Egypt during that time. In the process, the parliamentary democratic system was interpreted as a foreign imposition unsuitable to Nepali soil. From this point of view, supporting parliamentary or any western system would be an anti-patriotic, treasonous act. What is interesting in this whole context is that the king used the privileged genre convention and vocabulary from western modernity to assert his and thus the country's (because the country, from this new understating, served as his extension) “indefensible and inalienable rights" to "develop its political, economic and cultural life ... in accordance to its own genius and traditions right." He used the power built in the genre to introduce a nativist political system and to claim his right to do so according to his own "genius and tradition," while simultaneously rejecting the core ideological parts of the genre as foreign elements.

For the revolutionaries who had fought in the 1950s for democracy, the introduction of the 1962 constitution represented an anti-climactic moment. Their idealistic understanding of the constitutional genre that required the observation of an electoral process to claim the authorship 
was turned upside down. "The common bond of allegiance to the Crown" in the new constitution had replaced their need to craft a collective "we, the people" constitution through a legitimate electoral process. The king had used the genre to claim monarchical constitutional authorship as indigenous political right, displaying how genre conventions themselves get appropriated and repurposed by powerful players for achieving their goals.

Recapitulating the discussion of this section, we need to ask two questions regarding the generic performances of the 1959 and 1962 constitutions: how the genre structured the actors' choice, and what the actors used the genre for. The genre provided the king a modern legal, discursive space where he could transform his traditional cultural and political power in a new form, squashing the opposing undercurrents against his rule. With the adoption of the genre, the country might have chosen to be a modern nation-state, but the king claimed its unique identity by asserting a nativist political aspiration through the constitutions. In such aspiration, the king bended the genre itself, claiming his prerogative to constitutional authorship.

While the historical context was very different, the struggle over constitutional authorship in Nepal during this period resonates with the debate on sovereignty in seventeenth-century England. As Joyce Lee Malcolm has chronicled, the political tracts of the time forwarded multiple places for the location of sovereignty — " for the sovereignty of the king alone, for the king in parliament, for the two houses of Parliament and the House of Commons alone, for the sovereignty of the law and that of people" (XXI). Although the doctrine of individuals' natural rights would evolve around the same period, the tracts from the period recorded in Malcolm's book suggest that the location of sovereignty was more about a historically-formed discursive idea rather than a natural factor itself. While it was difficult for the king in Nepal in the twentieth-century to claim complete sovereignty explicitly because of the increasing 
globalization of modern constitutional thought and its adoption by Nepali revolutionaries early on in the 1950s, he managed to keep the sovereignty with him until the promulgation of the 1990 constitution. The King's divine right to ordain laws and the doctrine that the king can do no wrong were widely circulated during this period. Despite the preponderance of these claims, the king knew that he could exercise his authority only by holding onto the constitutional authorship. Again, context shapes genre. The 1962 constitution was not declared in a peaceful world. Within the country, the ousted Nepali Congress Party had declared an armed struggle against the king. The parties were breaking as the king offered appointments. The king needed to justify imposing his own rule because of the short constitutional history within the country, and also because growing internationalism demanded that countries fulfill certain discursive patterns such as maintaining a constitution. Crises outside of Nepal, however, meant that foreign powers did not have time to react seriously to Nepal's political development. The Cold War and Cuba crisis had enthralled the superpowers of the world. Nepal's two giant neighbors — India and Chinawere at war. To the degree that foreign powers were noticing Nepal's development, the king and his regime had forwarded enough rhetorical moves to justify the new constitution in 1962.

The 1962 Constitution served Nepal for the next 30 years. Although the king consolidated power during this period, Nepali society continued to undergo transformation because of the impact of accelerated globalization and modernity. Within Nepal, banned political parties such as Nepali Congress and a number of Communist parties created a large structure of cadres, many of them serving in jail for their involvement in outlawed political parties. Drawing their inspiration from Nepal's own short lived democratic past as well foreign sources, this group of politically active cadres dreamed of an idealistic political system ranging from western style democratic system to egalitarian communist polity. For them, justice and democracy served new 
mantras while feudal entitlements smoked stale, oppressive structural residues from the past. These cadres, many of them educated with western political books, formed a new political conscience of the nation as they used newly established colleges, expanding urban centers and remote rural hinterlands for mass mobilization and public sphere debates, mounting opposition to the king's autocratic rule.

Based on this analysis of the 1959 and 1962 Nepali constitutions, we can say that international public genres such as the written constitution do not always perform in a straightforward monolithic way. The form and its ideological disposition may shift when the genre moves from one time, location, and culture to another. As genre theorist Vijay Bhatia has stated, genres go "through rhetorical processes of recontextualization, reformulation, reframing, and resemiotization" in such context (25). In Nepal, the recontextualization of the written constitution genre involved the negotiation between the country's desire to open itself to the ideals of modernity and the pull of the tradition centered on the institutions such as monarchy and its supporting socio-economic base. That the constitution had to be written in Nepali and that it had to accommodate the linguistic traditions of glorifying monarchy meant that the recontextualization of the genre also went through language and cultural translation.

The transactions within translations were multiple: Nepali drafters learned the genre in English language as they employed English-speaking experts in the drafting process. But since the constitutions themselves were introduced in Nepali officially, the English translations of the constitutions written in Nepali tried to capture the meaning from the Nepali text while attempting to follow the genre's language convention in English. In this process of translation and transplantation, the constitution as a genre certainly influenced the context from its earlier enunciations, particularly by introducing the notion that politics should be governed by the words 
of the constitution, the idea that would have deeper ramifications in the vision and practices of state power in the subsequent national history. But the genre also was repurposed and resemiotized fundamentally: For instance, the king used the constitutional space to perform his mythologization, to claim the country's indigenous right to write its constitution, and to claim his constitutional authorship. In his efforts with the 1959 and 1962 Nepali constitutions, the genre had come to reaffirm some of the core traditional cultural and political values associated to hereditary power, privilege and entitlement, the same values against which the genre was invented in eighteenth-century America. Despite the king's deliberate bending of the genre in his favor, the fact that the country adopted the written constitution had its own metaconstitutional impacts that asked, among others, the king to define his source of power of authoring constitutions.

\subsection{The 1990 Constitution and the Compromised Collective Constitutional Authorship}

Before directly jumping into the 1990 constitution, a brief historical context is in order. In 1990, the rival Nepali Congress and communist parties formed a coalition and launched a political movement for the restoration of democracy. The context was ripe for change: it had already been a decade since the 1980 national referendum that gave a narrow victory to the king's reformed (party-less) Panchayat over a multiparty parliamentary system. During the same period, the relationship between the king and India deteriorated, leading India to revoke the transit agreement between the two countries, eventually blocking the transportation of goods to landlocked Nepal from Indian borders. The country faced a dire shortage of fuel and other merchandises, exposing how the government had failed in its basic responsibility to its people. Opposition to the king accelerated as India openly supported the opposition and as the growing Nepali middle class gained access to western and Indian television channels. The newly launched 
CNN was, for instance, automatically included in cable subscription and viewers could see the end of the Cold War and the democratization of Eastern Europe and other parts of the world in their own living room. The king was wise enough to notice the signals sent by the geopolitical context: had he crushed the movement further, the moderates within the opposition would have lost their control and the monarchy would itself have been their target. Responding to the movement, the king lifted the ban on political parties, opening up the process for writing a new democratic constitution in 1990. In the constitutional history of Nepal, the 1990 constitution presents an important turning point not only because the king accepted his position as a constitutional monarch for the first time but also because multiparty democracy was restored after 30 years. The 1990 preamble addresses issues of authorship, sovereignty and constitutionalism up-front by highlighting how these issues shaped the constitutional debates for the half century preceding this document.

Indeed, the preamble of the new constitution became the site of intense struggle between political parties and the king. The king wanted to preserve his sovereignty in the new constitution as well, but political parties refused to honor his interest. Ultimately, they forged a compromise in which the king announced the constitution while investing sovereignty in the people for the first time in the history of the country. Here is the preamble:

WHEREAS, We are convinced that the source of sovereign authority of the independent and sovereign Nepal is inherent in the people, and, therefore, We have, from time to time, made known our desire to conduct the government of the country in consonance with the popular will;

AND WHEREAS, in keeping with the desire of the Nepalese people expressed through the recent people's movement to bring about constitutional changes, We 
arc further inspired by the objective of securing to the Nepalese people social, political and economic justice long into the future:

AND WHEREAS, it is expedient to promulgate and enforce this Constitution, made with the widest possible participation of the Nepalese people, to guarantee basic human rights to every citizen of Nepal; and also to consolidate Adult Franchise, the Parliamentary System of Government, Constitutional Monarchy and the System of Multi-Party Democracy by promoting amongst the people of Nepal the spirit of fraternity and the bond of unity on the basis of liberty and equality; and also to establish an independent and competent system of justice with a view of transforming the concept of the Rule of Law into a living reality:

NOW, THEREFORE, keeping in view the desire of the people that the State authority and sovereign powers shall, after the commencement of this Constitution, be exercised in accordance with the provisions of this Constitution, I KING BIRENDRA AIR AIKRAM SHAH DEVA, by virtue of the State authority as exercised by Us, do hereby promulgate and enforce this CONSTITUTION OF THE KINGDOM OF NEPAL on the recommendation and advice and with the consent of the Council of Ministers. (Preamble, 1990 Nepal Constitution)

Every word in this preamble was chosen with careful scrutiny because of the mistrust among the major stakeholders. Although the king was going to announce the 1990 constitution, the political parties that had launched 1990 movement for the restoration of democracy wanted the constitution to be read like the product of the movement rather than a gift generously granted by a democracy-loving king. The palace on the other hand was fighting hard not to submit to any hints of its compromised constitutional authorship. Because of this struggle, as Michael Hutt 
records, the writing was not going smoothly_even after the king had lifted the ban on parties and invited them to form the government. ${ }^{78}$ For instance, the palace leaked its own (ultimately aborted) draft removing many clauses of the preamble from the version submitted by the Constitution Recommendation Commission. ${ }^{79}$ With the clauses in the preamble of the proposed constitution such as "in accordance with the desire expressed by the people of Nepal through the historic people's movement for Constitutional change" and "framed through the broad participation of the Nepali people in accordance with their desires," the framers tried to connect the constitution with the recently successful democratic movement (Hutt 1990, 1033). But the palace wanted to present the constitution as its gift to the people-not something undertaken on the pressure of the opposition. For that effect, the palace draft replaced the clauses quoted above with the expressions such as "whereas the happiness and prosperity of Nepal and the Nepali people have always been our [the king's] sole objective, and we [the king] are determined to achieve that objective, and whereas it is desirable to frame and promulgate a Constitution" (Hutt 1990, 1033). The palace-leaked draft also replaced the clause "on the advice and with the approval of [the] Council of Ministers" with "in accordance with the Constitutional laws, customs, and usages and traditions of Nepal" (Hutt 1990, 1033). One could easily see the reincarnation of the 1962 constitution in the leaked draft.

Promulgated amidst this bickering, the 1990 constitution was a document of compromise between the king and the dominant opposition parties from the perspective of constitutional

\footnotetext{
${ }^{78}$ See Hutt (1990), 1020-1039.

79 The members in the Commission included representatives from Nepali Congress, United Communist Front, and the palace - that reflected a changed power dynamic - with the view of drafting consensus document.
} 
authorship. ${ }^{80}$ It was a compromise forged by moderates within both camps. The compromise rested on the fact that while the king promulgated the constitution using his sovereign power, he used it to transfer his sovereignty to the people. The compromise gave both stakeholders, the king and the major political parties, an opportunity to interpret the constitution as their victory. For instance, although the 1990 constitution substantially reduced the king's power in comparison to the 1962 constitution, he could still feel symbolically significant because he performed (and thus maintained) his authority of constitutional authorship. While the constitution promised the rule of law, which in the context of the Nepal's constitutional history suggested an end to the king's power to play outside the constitution and thus the fear of liminal space as theorized above, the fact that he issued it preserved his central place as the source of the constitution.

Indeed, this sovereign act of transferring sovereignty to the people remained interpretatively ambivalent. The dominant political parties such as Nepali Congress and CPM (UML) that had become the ruling coalition during the constitution drafting process interpreted the action as the transfer of sovereignty from the king to the people. They emphasized the nonretractability of such transference - a rhetorically savvy hermeneutic move that presented the constitution as the climatic outcome of the people's movement for the restoration of democracy. From this position, once the words of the constitution start enforcing themselves by becoming the parts of a living and sovereign document, they automatically surpass the moment of their birth or the technicality of their parentage. Furthermore, the political parties interpreted the king's role in announcing the constitution merely as the commencement of a Westminster

\footnotetext{
${ }^{80}$ Another group of parties that characterized Nepali Congress and CPN (UML) as "establishment parties" would emerge following the promulgation of the 1990 Constitution. These parties would take the mantle of traditional revolutionary streak, while the "establishment parties" would exercise the state power.
} 
system. The constitution was, they argued, prepared by the Constitution Recommendation Commission, which the king had formed according to the recommendation of the government that the parties now controlled. The preamble also included a statement that the constitution was promulgated "on the recommendation and advice, and with the consent of the Council of Ministers." Interpreted from this angle, the king was merely acting as a ceremonial head rather than claiming the absolute constitutional authorship.

Royalists and ultra-leftist parties undermined this interpretation by emphasizing the retractability of the king's so-called transferred sovereignty, although they had their own peculiar interests in the claim. For them, allowing the king to announce the constitution suggested the incompleteness of the movement. Royalists highlighted the constitution as the product of the king's good will rather than the logical outcome of the movement, a position that not only suggested the provisional quality of the document but also the centrality of the king's fundamental righteousness. From this perspective, sovereignty was embodied in the king, the ultimate non-transferable source from where everything issued forth and to which everything returned. The ultra-leftist parties also rejected the dominant parties' logic, first arguing that the king's constitutional authorship automatically made him the sovereign even when he declared himself a constitutional monarch in the constitution, and second emphasizing that such acceptance always kept the liminal space of pre-1990 constitution technically alive. For instance, the Nepal Communist Party (Masal) stated, "We do not believe that the King will give up power and hand over sovereignty to the people. After all, even the new Constitution will be a gift from the King. How can a mango tree bear oranges?" (Quoted in Hutt, 1028).

These debates originated from the procedural purity engrained in the genre convention of the written constitution. While the royalists and ultra-left revolutionaries may have their own 
views, the fundamental warrant of their arguments suggested the importance of the provenance of a constitution. No matter what was written in the document, what mattered most was who issued the constitution. The chairperson of the Constitution Recommendation Commission Justice Bishwanath Upadhyaya captured this legal conundrum succinctly: "The individual or institution that gives a constitution is sovereign. The people will be sovereign if there is a Constituent Assembly, but we have not followed that path. If the Constitution is granted by the King, under what power should he do so?" (Nepal Press Digest 34:29, July 16, 1990; Hutt 19901029). What is important to note is that in the context of Nepal, the king held the constitutional power to announce a new constitution. Both the 1962 constitution, the country's constitutional tradition, and cultural framework provided the king the authority to issue a constitution. Upadhyaya's comments however emanated not so much from Nepal's particular constitutional context; the comments came in reference to the genre convention. As a transnational genre, a written constitution had to follow some form of electoral procedure to establish a popular collective national authorship. In the absence of such procedure, a constitution would not be legitimate and binding because the governed had not expressed their consent to the main law through which they wanted to be governed. The 1990 constitution certainly hinted at this generic requirement in the preamble; it claimed that the constitution was "made with the widest possible participation of the Nepalese people." Mere participation by sending suggestions to the drafters or making comments on the draft before the pronouncement did not, however, meet the necessary condition for the popular mandate within the genre convention. Upadhyaya knew that a handful of people like him, often with a predominant role of single individuals (think of James Madison as the father of the U.S. Constitution or Ambedkar as the major drafter of the Indian Constitution), practically drafted a constitution. For the document to be legitimately owned by 
the country, the genre convention required it to be announced with collective national authorship.

Undoubtedly, the absence of such collective authorship left an opening for challenging the constitution even after it came into operation. But even more critical for the demise of the constitution became the words in the constitution itself, particularly its unalterable provisions. Clause (1) of article 116 states: "A bill to amend or repeal any Article of this Constitution, without prejudicing the spirit of the Preamble of the Constitution, may be introduced in either House of Parliament: Provided that this Article shall not be subject to amendment." The tenword-rider inserted within the clause qualified the amendment, stating that constitutional monarchy and parliamentary democracy hallowed in the preamble were permanent, nonamendable features. Certainly, this qualification assured both the king and major political parties their future security at the moment when distrust was the prevailing emotion between them: The parties wanted to block the king to from repeating any action such as dissolving an elected government or announcing a new constitution in the fashion he did in the1960s. The king wanted to use the constitution to strengthen the longevity of his increasingly anachronistic institution. But this desire for permanence weakened the collective constitutional authorship as it imposed a decree from that generation to the next—not allowing the future to choose their own political system. Speaking from the perspective of genre convention, this assertion to permanence failed to observe the core ideological promise in the genre of the written constitution.

The core of a constitution in its idealistic genre form is its promise of unlimited amendment. While forged by one generation of the people, the legitimacy of the collective constitutional authorship such as "we the people" of the U.S. Constitution depends on the promise that the people can rewrite their constitution by following a specified procedure. With 
the promise of unconditional constitutional amendment, "We the people" of the constitution starts to represent even those people without any role in writing or amending it. With the promise, the collective authorship exerts its representative power to anybody with national citizenship. It is for this effect that Thomas Jefferson argued for every generation to write their own constitution. As the experience of the United States suggests, while constitutional amendment should not be an easy process as it would destabilize the political system, the unqualified amendment provision allows the possibility of the constitution's continuous rewriting to include the will of the future generations. In a sense, the core or permanent element of a democratic constitution rests on the inalterability of its open amendment provision with a particular procedure. Any limitation imposed upon such provision thus would automatically violate the spirit embodied in the collective national authorship.

Besides the unamendable provisions, the 1990 Constitution also generated other substantial questions regarding the authorship and sovereignty. While the 1990 constitution had established the sovereignty of the people in principle, who were defined as "the people"? ${ }^{81}$ Do all citizens have the equal access to their sovereignty? Scholars have extensively pointed to the exclusionary nature of the 1990 constitution. ${ }^{82}$ David N. Gellner incisively illustrates the

${ }^{81}$ Think of the place of slaves and women in the 1800s in American elections. The issue of representation may look like a settled phenomenon now as it always does when it is viewed from the dominant angle of the time, but even in the United States there is a long way to go to respect the sovereignty of an individual in its electoral process.

${ }^{82}$ See Jones and Langford for their analysis of how Nepal's indigenous rights movement played out during the constitution drafting process after the elections of the Constituent Assembly, particularly in light of the Convention Concerning Indigenous and Tribal Peoples in Independent Countries ("ILO Convention 169"). They observe that different Nepali actors interpreted the ILO Convention 169 differently, creating the chasm between accepted international meaning and the national needs: "Reconciling international meanings of this treaty with national interpretations used for political purposes in Nepali foregrounds a paradox existing between liberalism (in the forms of rights and freedoms) and equality (democracy)" (369). 
challenge posed by "the rise of this new kind of rights discourse, with its emphasis on the rights of minority cultures" to "the liberal political and judicial theory" with its "more traditional ways of conceiving rights" based on individual rights than on community-based collective rights (177). As he argues, in the context of the rise of the discourse of minority rights as a global phenomenon, Nepal changed its conception of nationhood from the "old definition of Nepal as 'an independent, indivisible and sovereign monarchical Hindu Kingdom'” as conceived in the 1962 constitution, to the 1990 constitution's “multi-ethnic, multilingual, democratic, independent, indivisible, sovereign, Hindu and Constitutional Monarchical Kingdom" (185).

Such recognition alone was insufficient "to combat Brahman domination of the political, legal and administrative machinery" (187) and to bring about "different yet equal model" of multiculturalism (193). Mahendra Lawoti for instance presents four major provisions in the Constitution such as "banning ethnic parties," "the lack of equal recognition of differences among cultural groups and adoption of dominant values and norms," the absence of "substantive minority rights" and "majoritarian state-structure" as responsible for constitutionally engineering the exclusion of traditionally marginalized groups such as the indigenous nationalities, Dalits (traditional untouchables), Madhesis (plain people) (50). This exclusion caused the "disjunction between state and society" undermining the participation of "more than two-thirds of the population, including the indigenous nationalities (Adibasi Janajati), Dalits (traditional 'untouchables'), and Madhesis (plains people) in the mainstream governance (Lawoti 23). In her excellent analysis, Mara Malagodi posits the origin of 1990 Constitution's exclusionary nature in the dominant ethno-cultural national identity that emerged with Prithivi Narayan Shah's conquest in the 1800 s and was strengthened further by legal and political processes such as Muluki Ain and the 1962 constitution. While the framers of the 1990 constitution aimed at a 
liberal, democratic constitution, they did not fundamentally transform "a monolithic and exclusionary constitutional definition of nation" (Malagodi 3). She points out that despite stating the principle of equality, the 1990 Constitution ended up perpetuating the hilly high-caste Bahun and Chetris dominant ethno-cultural national identity by adopting Hindu religion, Nepali language, and monarchy that constitutionalized the exclusion of large sections of society.

The shifting political landscape has deep implications for the genre of constitution. Merely stating the fundamental rights of the individuals was not sufficient to address the question of democratic equality and access. The bill of rights kinds of provisions were understood more as the negative, restrictive statement designed to stem a majoritarian government from encroaching on the life of private citizens rather than as the statement to activate their positive sovereignty and citizenship. ${ }^{83}$ While impartial and applicable to all technically, the doctrine of individual rights facilitated sovereignty only for those who could use it because of their already privileged position. For the state to ensure the inclusion and representation of the marginalized, the constitution needed new procedures and practices to address engrained structural inequalities. For establishing the context of positive participation, the constitution also needed to acknowledge certain ethnicities and castes not only as distinct identities but as marginalized (thus unequal) categories and make them the part of representation. Such kind of caste or ethnicity-based representation undermined the positivist, modern doctrine of individual equality. But postmodern identity politics and the ideas of inclusive democracy demanded the inclusion of those identities as marginalized one, proving reservations. This contraction exposed the fissures within the equality discourse of modernity.

Because of the compromise in the authorship, the 1990 Constitution came under attack

\footnotetext{
${ }^{83}$ See Isaiah Berlin's book, particularly the essay "Two Concepts of Liberty" (pp.118-172), for positive and negative definitions of liberty and its association with classical republicanism.
} 
within a decade of its promulgation. The Nepal Communist Party (Maoist) started an armed revolt to establish a communist system, making the elections of the constituent assembly its bottom-line to give up its arms and to immerse in the mainstream politics later. The 1990 Constitution could not fulfill this demand because of its qualified provision for amendment. Maoists also used a growing ethnic discontent to advance their cause by supporting ethnic nationalism. In 2005, the new king broke the 1990 compromise by dissolving the existing government and parliament as he started direct rule through a handpicked government. Protests mounted against the king's rule, bringing armed Maoists and the parliamentary political parties such as Nepali Congress and CPN (UML) together with a seven-point agreement signed between them. The coalition launched the movement for the restoration of the dissolved parliament and the election of the constitution assembly. Ultimately [the opposition prevailed; the king restored the parliament, returning power to the political parties. The restored parliament abrogated the 1990 Constitution, suspended the monarchy, and promulgated an Interim Constitution in 2007 to hold elections for the Constituent Assembly.

In this swift, dramatic history, at least two aspects are remarkable from the perspective of constitutional history, authorship, and sovereignty. First, a disagreement occurred within the coalition regarding the path ahead. While the coalition partners agreed on the new people-written constitution, they wanted to achieve the goal differently. Maoists wanted complete disruption of the past constitutional process so that they could go directly to the elections of the Constituent Assembly. The Nepali Congress, particularly its leader Girija Prasad Koirala, focused on following the process within the existing constitution. Certainly, it was not possible to hold the elections of the Constituent Assembly or to suspend the monarchy with a literal reading of the 1990 constitution. The coalition finally agreed on the Koirala's argument of following the 
constitutional process. As Krishana Prasad Situala, who played an important role in the process and would later serve as chairperson of the drafting committee for the 2015 Constitution, recalls, the restored parliament did not follow the existing law or the constitution in the way originally intended by the framers of the 1990 Constitution (http://setopati.com/raajneeti/47367/). As he emphasizes, the point was to move ahead while causing the least possible damage to the constitutional procedure.

One major reason for following the constitutional path was that the parties themselves were fierce rivals and held different political philosophies. Although they had agreed on the election of the constituent assembly, the kind of constitution they wanted from the Constituent Assembly was as different as a Maoist communist state to parliamentary democracy. They could manage the conflict among themselves in the future only by respecting the constitutional procedure. It was an agreement to play within the rules so that results after the tournament would be binding to all players. In a sense, with this decision, the parties decided to respect and thus continue the constitutional process started by Padma Shumsher in 1948 rather than having a disruptive new beginning in the fashion Mao did in China.

Secondly, once the parliament was restored, it assumed complete sovereignty arguing that it had achieved the people's mandate through both electoral and revolutionary processes. Instead of respecting every word in the 1990 constitution, the parliament made the clause "sovereignty is vested in the people" prominent, undermining other provisions. Assuming full sovereignty without any restrictive qualifications, the restored parliament interpreted the1990 Constitution from the point of view of people's sovereignty (not the "rule of law") perspective. This interpretation that the parliament was fully sovereign led to many powerful political transformations. The parliament changed its existing composition as it appointed 73 new 
members to represent CPN (Maoist); it took over the role of an active constitutional authorship by declaring the 2007 Interim Constitution that suspended the monarchy; made the prime minister the head of the state; and declared the election of the Constituent Assembly for a permanent constitution.

This development is similar to Kenneth Burke's characterization of the American constitution. The Constitution, he argues, is not a coherent, single motivational document. He contends that the Constitution is a document with contradictory wishes, where which wish gets to be rewarded depends on the power dynamics of the context. For instance, the restored parliament foregrounded certain aspects of the 1990 constitution, especially the idea that sovereignty rested on the people and that the parliament had the people's mandate to use the sovereignty. Interestingly, the king had interpreted the same constitution differently, indicating that his emergency intervening power was supreme among the provisions. But as soon as the parliament got hold on the power, the sovereignty statement in the constitution received unprecedented prominence. This anecdote, along with Burke's characterization of the Constitution, gives us important insights into the function of the constitution as a genre. As the two different uses of the 1990 Nepali constitution suggested, the inherent epistemological incoherence of a document leads to divergent interpretations producing unexpected generic performances.

\subsection{The 2015 Nepal Constitution and the Genre's Ideological Fissure}

The ideological battle about the legitimate constitutional authorship that engulfed Nepal for more than half a century came to end in 2015 when the Constituent Assembly promulgated the new republican Constitution. The debate about the location of sovereignty was finally resolved with the idea that the hereditary king did not have a place in the people's polity. The 
new Constitution scrapped the monarchy and tried to be the vehicle of an inclusive democracy by devolving power from Kathmandu to local levels and by promoting the representation of marginalized groups. From the perspective of constitutional history, the long conflict of constitutional authorship had ended, inaugurating a post-liminal phase. There would be no king to suspend the written constitution and the sovereignty described in it. No external authority outside the Constitution could claim to be the sovereign self. The force of writing had totalized the world-anything done in the name of the state had to be backed up with the words in the hallowed text. While it has its own unique inflections, the 2015 Nepali experimentation restored the main ideological underpinning of the genre of the written constitution in the way it established the dominant international tradition — both by authoring the Constitution by the body of elected representatives and by eradicating the space for the politicians to play outside constitutional domain.

From the perspective of Nepal's constitutional history, this moment should have been a point of celebration. But the reaction to the new Constitution was not as positive as anticipated. The political parties that claimed to represent the voices of a large section of people in the southern parts of the country opposed the Constitution. They claimed that the Constitution has not addressed the historical gap of power between hilly elites and the indigenous southern inhabitants. Unhappy that the Constituent Assembly had not heeded suggestions sent via direct and indirect diplomatic channels, India unofficially blocked the transit routes, not only creating a massive shortage of essential supplies in Nepal but also inducing intense anti-Indian sentiments, such as the one expressed on Twitter with \# backoffIndia https://twitter.com/hashtag/backoffindia?lang=en). The promulgation of the Constitution had revived the old fears of national independence and sovereignty. 
The question becomes, why could the new Constitution not be welcome news for all? What does the rhetorical genre perspective offer us that standard political science or legal studies does not in this regard? As explained in the introductory chapter, the written constitution as a genre is a historical construct of modernity that depends on the participants' belief in its procedural rationality for its own legitimization. Ideas such as self-governance, constitutional authorship of the people, and equality of representation in government are at the ideological core of the genre and are pragmatically materialized through an electoral process. In the dominant genre convention that emanated from western modernity, a mathematical model tries to assign equal numerical values to the electors; the mathematical process rationally produces the constitutional authorship, governing mandate, and the will of the people. Written constitution in its dominant genre convention legitimizes itself by promising fairness and equality. Using a metaphor from the world of sports, written constitution as a genre provides a set of rules for a national political game. It claims the superiority of its set of rules by evoking the master terms of modernity such as equality, self-governance, and objectivity. But its reliance on mathematical models for translating these ideals into practice automatically produces winners and losers. Games perfectly work until winners and losers do not question the fundamental rules of the games. But once the rules themselves are questioned, games stop operating because players do not agree on the basic fairness or premises of the rules, of what should be awarded or punished in the games.

In the case of Nepal in 2015 , the procedural rationality at the core of the constitutional genre itself had become insufficient. As Kenneth Burke has argued, constitutions work mostly because they can embody many contradictory claims to satisfy large sections of society. A constitutional text may include many wishes, but not all wishes. In the case of Nepal, this 
pragmatic impasse within the procedural rationality at the core of constitutional genre coupled with the postmodernist questioning of the master terms of modernity, generated radical democratic wishes, to the point that fulfilling some extreme demands required the deconstruction of the state itself practically. A national constitution as a genre may try to bind the state to certain laws, but it does not hold the capacity to deconstruct the state itself. Many parties in Nepalparticularly those ethnic and regional marginalized communities that wanted to use the Constitution to establish their autonomy - found the basic procedural phenomenon in the constitutional genre not fair enough for their condition. As a result, even when the Constitution garnered an overwhelming majority, those who objected to it found it exclusionary, questioning the constitutional system itself. Instead of agreeing to the results coming from the used model, they looked for tangible results in the world. Constitution for them could be acceptable only when it fulfilled the tangible wishes pressing the moment.

Thus, while Nepal promulgated new Constitution in 2015, and the state has been operating using this Constitution, the context in which it was drafted created a special challenge for the genre to actualize a performance. Almost all the political philosophies from classical republicanism to ultraleftist Maoism, from liberal democracies to traditional monarchism, had representation in the Constituent Assembly. Besides, marginalized castes, ethnicities, localities, and gender also wanted the Constitution to fulfill their aspirations. In a sense, the debate on writing the new constitution opened various wishes suppressed under authoritarian governments in the past. Encompassing all these wishes into a workable system tested the elasticity of the genre itself. 


\section{Chapter 5. The Genre of Written Constitution: Where Does It Stand Now?}

This leads us to the ideology of the genre of the written constitution. Genre theorists cited in the introductory chapter have argued that a genre holds an ideology — a certain disposition, a way of thinking and doing things. Then question becomes this: based on all these transnational and transcultural performances, what can be said of the major ideological trends of the written constitution? Where does the republican aspiration that gave birth to the genre stand now? And what does the answer help rhetorical genre scholarship to understand genre further?

An overarching theme throughout the preceding chapters has been how the genre of the written constitution emerged in the United States in the late eighteenth-century and how thinking about a nation-state in the subsequent global history required the use of the genre. The chapters emphasized on the indispensability of the written constitution for the construction and imagination of a nation-state; without a written constitution, modern nation-states cannot think of garnering the recognition of statehood from the global community. Nor a ruler-no matter how antithetical his actions to the core ideology of constitutionalism — within a country can legitimize his regime without the use of the written constitution. Thus, while constitutionalism is the idealistic core of the written constitution, the practices suggest that its ability for legitimization has been the main attraction and function of the genre. In its long history, the genre has come to be an iconic form of a secular nation-state that articulates and governs various visions and practices of sovereignties and submissions. From this perspective, the main function of the written constitution has been to provide a stable governing formula and method of legitimization for a secular world. ${ }^{84}$ The dominant global political culture of the modernity and postmodernity

\footnotetext{
${ }^{84}$ Undoubtedly, the written constitution has been used to establish theocracies. As discussed in the introductory and subsequent chapters, the written constitution has a secular republican ideological origin that emphasizes on the capacity of collective human reason to determine and
} 
cannot be described without the function carried out by the written constitution.

By now, this dissertation has established a few conclusions about some of the transnational and transcultural performances of the written constitution. Indeed, the written constitution embodies and exerts certain ideological conditions irrespective of the exact location of its use. However, the exploration of the motives, historical contexts, and textual experimentations in the three contexts suggested that users also use the genre creatively to fulfill their specific contextual needs. For instance, the main genre function of the written for the framers of the U.S. Constitution was the externalization of republicanism: the genre served them as a conduit to move from what I termed 'subjective republicanism' to a version of codified and written republicanism that can be objectified, discussed, and even amended. The main function of the Cherokee adoption of the 1827 written constitution was its ability to be a part of the larger politics of identification that the nation was launching during that time. From the perspective of the contemporary Cherokee elites, their adoption of the constitution would demonstrate the unfurling of the Cherokee progress as anticipated in the federal program of Indian Civilization. They thought that the mimicry would gain them an existential independence and sovereignty, a respect deemed for a foreign nation as promised in the U.S. Constitution. The chapter on Nepal's constitutional history demonstrated how conflicting and uncompromising visions of constitutional authorship pushed the country through a difficult transition period of seven decades. The chapter highlighted how the notion of constitutional authorship — something historically produced and procedurally crafted by using relevant genre conventions - could be contentious producing different narratives to justify different political interests.

govern its destiny. Thus, the genre's core ideology is anti-theocratic in spirit. But the fact that the modern global community expects a nation-state to have a written constitution forces even theocracies to adopt the genre. 
This analysis of the constitutions of the United States, Cherokee Nation and Nepal leads us to the challenge at the crux of the written constitution as a genre faced by both the framers in eighteenth-century America and twenty-first-century appropriators in Nepal: the impossibility of creating a perfect governing system while simultaneously materializing all citizens' positive sovereignty. The challenge emanates from the twin aspirations of the constitutional genre: On the one hand the written constitution has evolved into an idealistic space to state lofty principles of equality, freedom and dignity of all people. As the main political genre of modernity, it promises to be a major vehicle of fulfilling the Enlightenment ideals. On the other hand, a written constitution as a governing document needs to craft a procedure to create a mandate for a handful of people to govern a country. In a sense, it must be both an idealistic aesthetic promise as well a technical governing tool-a poem as well as a users' manual. This gap may not be apparent to the people living in a country with a long-held constitution such as the United States. In such context, the rule of the political game has largely been already set, and thus players think more of gaining the maximum leverage within the established rules rather than thinking of the rules themselves. But the rift comes thunderously alive in the context where participants of the genre are trying to mold it for their own situation. For instance, participating in the debate regarding the content of the preamble of the 2015 Nepali Constitution, some operation-minded politicians such as Ram Saran Mahat argued that constitution or its preamble should not include political history or even principles of governance. From an operationalist perspective, a constitution should be a bare governing document like a set of rules for a game. But many others thought of the purpose differently. They contended that the 2015 constitution itself was a historical achievement, a glory to be celebrated. Thus, they argued, it should document the glorious history of sacrifices and the principles of governance in the constitution for which the parties and people 
had fought hard. As the 2015 preamble stands now, it refuses to be a mere governing document as it includes the national history from the winners/drafters at that moment as well as the ideals of the new republic.

While the conflicting forces of idealism and practicality engrained in the genre of constitution are not necessarily antithetical attributes in themselves, the gap between them not only disfigures the principles on which a constitution is built but also often makes the document defunct. The 1990 Nepali constitution is its perfect example. Widely claimed to be the model constitution of balance and democracy, the 1990 constitution presented equality, democratic participation and the rule of the people as its major principles. These principles opened space for free discussion of ideas, including the voices of many marginalized communities and the need to fulfill the constitutional promise of equal participation in practice. But the rigid amendment provision as discussed earlier made it impossible for the document to transform its principles into a governing mechanism - ultimately making itself obsolete in the new context.

As the 1781 Articles of Confederation demonstrated in the U.S., letting the local governments remain sovereign was an idealistic expression of republicanism in principle, but the Articles failed as a governing document because they did not possess the procedure to create a governing mandate for the national government. Aware and worried that republican form of government could turn into a majoritarian tyranny because of the principles' translation into governing procedure, American framers instituted the bills of rights to ensure the protection of minority. Certainly, the bill of rights squelched some opposition to the Constitution in the early national period, but as the rest of history shows, the practice carried out in the name of the Constitution has remained far from perfect from the perspective of republicanism itself. "For a more perfect union"- the words in the preamble expressing the objective of the U.S. 
Constitution-have come to represent this perpetual imperfection and the hope.

Despite the imperfections, the success of democratic processes of the United States and other western countries, particularly their ability to hand over power periodically from one government to the next peacefully and to expand democratic rights to marginalized groups through constitutional reinterpretation or amendment, has established a level of normalcy for majoritarian democratic process in the world. ${ }^{85}$ The majoritarian rule through periodic election, a system of check and balances among the branches of government, and the fundamental rights against the government's encroachment into individual private life have established a functional system that somehow balances the idealistic goals associated to individual sovereignty and the pragmatic need of having to craft a governing mandate.

When Nepali revolutionaries fought for a people-written constitution for at least seven decades, they were guided by the idealistic aspirations embodied in the written constitution. But the 1990 Constitution and the early opposition to the 2015 Constitution revealed that normalcy created around the genre of constitution by modernity - particularly by the practices of the United States and many other western democracies — had become insufficient to postmodern aspirations. As explained earlier, the 1990 constitution failed despite being described as a model democratic constitution because of its compromised constitutional authorship and the limited sovereignty of the people because of conditional amendment provisions. Even the promulgation of the 2015 Constitution — supported by an overwhelming two thirds majority of the Constituent Assembly (507 of 598 members) — did not garner the kind of celebration deserved by the historical struggle for this moment: the definition of sovereignty, authorship, and democracy had

${ }^{85}$ Certainly, periodic election does not always generate democratically inclusive results. The rise of Hitler for instance is an example of how majoritarian rule can turn into an ugly campaign of minority genocide. The event confirmed Madison's fear expressed during the Constitutional Convention in 1787. 
lost its legitimacy in the postmodern political landscape. The abstract "we the people" crafted through majoritarian electoral process for creating a functional document has itself become inadequate. In such inadequacy, the ancient republican spirit of liberty has revived, where every individual would exercise his or her free-will instead of agreeing to a procedure that automatically assumes the subsuming of his or her self in the abstract "we the people" without meaningfully allowing his or her will to make a difference. 


\section{Chapter 6: Epilogue: A Short Meditation on the Pedagogical Implications of this Study}

While I narrated some of the context-specific functions of the written constitution from earlier chapters, the rest of the epilogue is a meditation on the pedagogical implication of my study reported in this dissertation. My overarching question for this purpose is this: What does the Written Constitution as a Genre Teach Us about the Teaching of Writing? Genre theorists such as Bazerman, Miller, Swale, Devitt, and Bawarshi have widely commented and established the significance of rhetorical genre studies to the teaching of writing. Indeed, the whole discussion of the genre studies in this dissertation has some relevance to the teaching of writing. The discussions on how genre functions differ from one context to the next ask writing teachers to be sensitive to the structure, ideology, and purpose of the genre. One interesting insight from this study suggests that people can use a genre for the unexpected purpose: who would have thought at the Philadelphia Convention that the Cherokees Nation would draft the Americanstyled constitution to claim its independence within the next few decades? Or, who would have anticipated that a republican-inspired genre was going to be used to justify monarchy in Nepal? What this suggests is that while a genre-focused assignment in a writing class may have specific learning outcomes designed by the instructor, students may use the genre for other purposes besides meeting the objectives set for the assignment. What they gain from the genre depends on students' disciplinary background, future aspirations, and other hosts of reasons. Knowing that aspect of teaching writing which an instructor cannot fully control sheds new lights on the impact of teaching.

While much can be discussed about the implication of genre studies, for delimitation, I use the idea of the threshold concept, pondering what the process of the writing of the constitution can reveal to us about the nature of collaborative writing that we can use in the 
teaching of writing. Rhetoric and composition scholar Kathleen Blake Yancey argues that the threshold concepts of composition studies serve as the "articulation of shared beliefs providing multiple ways of helping us name what we know and how we can use what we know in the service of writing" (xix). As Yancey and the contributors in Linda Adler-Kassner and Elizabeth Wardle's edited collection, Naming What We Know: Threshold Concepts of Writing Studies, state threshold concepts are more about the articulations of ideas that we already know than about proposing anything completely new. So, what I'm going to write about is not something new, but an articulation explained using the cases discussed in this dissertation.

Following their lead, here is a new threshold concept of writing as manifested by the three major cases of transnational, transcultural contexts of constitution writing: a high-stake collaborative writing is complex and contested in nature — not always a friendly and smooth process as the adjective "collaborative" in the expression may connote. By "high stake collaborative writing," I am refereeing to those public, professional and personal kinds of writing projects that are transformative of people's lives in effect. Some examples of high stake writings are constitutions, laws, and policy papers; these kinds of writing are highly performative in the sense that their enforcement holds the possibility to bring out dramatic changes in the sociopolitical conditions and power distributions in their historical contexts. In a high-stakes writing, collaborators bring in conflicting ideologies, identities and interests in the writing process, and they also perceive that the outcome of the writing project would significantly impact them, forcing them to maneuver the writing toward their interest and ideology, a condition that may compromise the logical progression of the writing process in the absence of a pre-writing agreement regarding how they would follow the process for the project's completion.

In the transcultural, transnational and historically different contexts of constitution 
writing that I examined in this dissertation, conflict surrounded the writing process. For instance, in the United States in the 1780s, it was hard enough for the participants of the Philadelphia Constitutional Convention to come up with an agreed upon document, and the ratification process that followed the drafting of the Constitution was not less contentious. While the general Enlightenment philosophical platform provided the participants a system for exchanging ideas meaningfully in the convention, both the ideological and pragmatic differences among them made the Constitution writing process a heated business in the summer of 1787. Adopting a western-styled written constitution was not an effortless process for the Cherokee Nation in 1827 as well. The introduction of the written constitution would transform the Cherokee culture dramatically. With the constitution, the power would be centralized, and many local chiefs would lose their traditional clout. Now, the power would be delegated to an abstract procedure-based abstract system. As the historians — discussed in the chapter three-have highlighted, the adoption was a painful realization for many of the framers themselves, and the reformist elites needed much rhetorical maneuvering to convince the traditionalists that the espousal of the foreign genre was worth the trying in their existentially challenging context. The internecine bloodshed that followed in the next decade cannot be dissociated from the 1827 constitution. The bloodshed suggests the intensity of the conflict and the cost of the compromise generated through the collaborative writing.

Indeed, the need of having to come up with a common governing document in the cases of constitution writing projects like the ones explored in this study also suggests an almost unavoidability of some degree of symbolic violence. In these contexts, participants have deep ideological differences, and they put substantial effort to make their position a winner in the final written product. Often, they attach their honor and identity with their views. But the process 
requires all participants to comply with the outcome even when they disagree with the spirit of the document. Whether someone cast his vote in favor of the ratification of the Constitution in 1789 or not, he is bound under the jurisdiction of the Constitution. Indeed, the framers tried to be inclusive - requiring a two-thirds supermajority of states for the ratification. ${ }^{86}$ The provision of two-third majority itself, however, was proposed knowing that total consensus among all the states was an impossible proposition. And, as discussed in the second chapter, the Constitution certainly included rights for the minority to ensure that opponents' honorable existence. But, despite these efforts to address the discontent, symbolic violence ensues from the structural need for a country to have a common document for the governance. Indeed, in some way, this structural need compromises with the sanctity of individual sovereignty valued deeply by a strand of classical republicanism - something that resonates with a version of contemporary libertarianism.

The discussion of symbolic violence here is not aimed at questioning the procedural nature of crafting governing mandate — either to pass a law or elect a public office holder — in the genre convention of the written constitution. Numbers, majority, and votes matter in modern politics. In the absence of better alternative, thinking of shared governance requires the quest of a common law, and the devising of the common law itself requires some sacrifice of differences. Reaching a common ground demands a pruning of some divergences. While the events of the post-1990s questioned his claim, this structural need for the governance makes Francis Fukuyama's the end of history thesis attractive. He argued that that liberal western democracyas articulated in the U.S. Constitution - has won the ideological battle with communism and that

\footnotetext{
${ }^{86}$ Inclusive in certain sense. But its exclusion of women, African-American, and other demographics is well researched and commented.
} 
no further development in the idea of governing system can be expected in the future. ${ }^{87}$ The history of political ideas has come to an end. ${ }^{88} \mathrm{My}$ aim to highlight this aspect was to foreground the complexity involved in high-stake collaborative writing.

This threshold concept that collaborative writing is a complex and contested process rests on other threshold concepts of writing studies. Victor Villanueva writes, "writing provides a representation of ideologies and identities" (57). Articulating another threshold concept of composition studies, Andrea A. Lunsford writes, "writing is informed by prior experiences" (54). Heidi Estrem states, "disciplinary and professional identities are constructed through writing” (55). Charles Bazerman and Howard Tinberg go even further and argue that, "writing is an expression of embodied cognition" (74). Placing these concepts together in the context of collaborative writing, it can be said that writers bring in different embodied cognitions, ideologies and identities. While the need of coexistence may have forced them to collaborate, often the collaboration of people with different interests and ideologies is charged with conflict. Such collaboration demands us to critically examine how the process of collaboration goes, who get to assert their agency in the process, how they negotiate what they are going to write, and how they manage their differences. Thinking collaboration by considering these factors has the

\footnotetext{
${ }^{87}$ My answer to Fukuyama: given what genres we have now for political operations, your hypothesis is correct. But it makes me hopeful that we have realized that the problemparticularly of symbolic violence - exists, and that new genre can be developed, or that the Constitution itself is open for a new form of governance acceptable to a larger majority. Studying genres, their histories, and the possibilities of genre uptake indicates that the existence of huge structural impasse should not lead us to declare the end of the history itself. Indeed, the history does not have to be linear, monodirectional or progressive. While we can be celebrating it in many ways, the last century was also a testament of the human capacity for ruin, destruction, and violence. But that testament or the structural impasse seen against the odds for the further 'republican' progress in the western liberal democracy, for now, itself does not question the possibility of the genesis of a new genre. Which directions the history goes cannot be prognosticated, but not the end of the history of ideas itself.

${ }^{88}$ See Fukuyama.
} 
capacity to transform the way we approach collaborative writing.

One way to understand the complexity of collaborative writing is to distinguish between labor-intensive and ideological collaborations. In labor-intensive collaboration, writers work together to get a thing done. Not much philosophical differences exist among them. The collaboration takes place either because of the size of the task or the need of the different expertise from the collaborators. The collaborators in this context try to solve a technical problem: they may disagree on how to complete a task or solve a technical problem, but the disagreement does not involve much philosophical substance. In ideological collaboration, a problem certainly exists, but it's more of legislative, social or of political kind. This kind of collaboration may not have a big bulk of writing task itself, but a difficult exchange of public rhetoric. Collaborators bring in their deeply held beliefs, arguments to support the beliefs, and interests behind those beliefs. Often, collaborators must be sensitive to the constituent that they represent. So, ideological collaboration is an exercise in public rhetoric, and thus charged with complexity and conflict. While the two categories are not completely separable in practice, having the categories and knowing differences between them positions teachers to approach collaboration with clarity and purpose, suggesting them to take appropriate pedagogical route. 


\section{Works Cited}

Adams, Willi Paul. The First American Constitutions: Republican Ideology and the Making of the State Constitutions in the Revolutionary Era. Translated by Rita and Robert Kimber, published by A Madison House Book, originally published in 1973, expanded edition published in 2001. Print.

Adhikari, Indra. Military and Democracy in Nepal. New Delhi \& London: Routledge, 2015.

Adler-Kassner, Linda, and Elizabeth Warble, editors. Naming What We Know: Threshold Concepts of Writing Studies. Classroom ed., Utah State University Press, 2016.

Agamben, Giorgio. Homo Sacer: Sovereign Power and Bare Life. Trans. Daniel Heller-Roazen. Sandford UP, 1998.

---. State of exception. Trans. Kevin Attell. U of Chicago P, 2005.

Amar, Akhil Reed. America's Constitution: A Biography, Random House, 2005, Print.

Anderson, Benedict. Imagined Communities: Reflections on the Origins and Spread of Nationalism. Verso, 1983. Print.

Anderson, Virginia. “Antithetical Ethics: Kenneth Burke and the Constitution.” JAC: A Journal of Composition Theory 15.2 (1995): 261-279.

Appadurai, Arjun. Modernity at Large: Cultural Dimensions of Globalization. University of Minnesota Press, 1996. Print.

Appleby, Joyce. Liberalism and Republicanism in the Historical Imagination. Published by Harvard University Press, 1992. Print. 
Arnold, Corroll C. "Early Constitutional Rhetoric in Pennsylvania." American Rhetoric: Context and Criticism. Editor Thomas Benson, Southern Illinois UP, 1989, pp. 131-200.

Austin, J.L. How to Do Things with Words. Oxford UP, 1975, first published in 1962, Print.

Bakhtin, Mikhail. The Dialogic Imagination: Four Essays. edited by Michael Holquist, translated by Holquist and Carly Emerson, University of Texas, 1981. Print.

Bailyn, Bernard. The Ideological Origins of the American Revolution. Published by The Belknap Press of the Harvard University Press, 1967. Print.

Baral, Lok Raj. Nepal Nation-State in the Wilderness: Managing State, Democracy and Geopolitics. Sage: New Delhi, 2012.

Barthes, Roland. "The Death of the Author." Image-Music-Text. Ed. And trans. Stephen Heath. New York: Hill and Wang, 1977. 142-148.

Barnett, Randy E. Restoring the Lost Constitution. Princeton, Princeton UP, 2004.

Bawarshi, Anis. "Beyond the Genre Fixation: A Translingual Perspective on Genre." College English 78.3 (January 2016): 243-249.

---. Genre and the Invention of Writer. Logan: Utah State UP, 2003.

Bazerman, Charles. A Rhetoric of Literate Action V 1. Perspectives on Writing Series. Editor, Susan H. McLeod. Fort Collins: The WAC Clearinghouse, 2013.

---. Constructing Experience. Carbondale: Southern Illinois University Press, 1994.

---. "The Life of Genre, the Life in the Classroom." Genre and Writing. Eds. W. Bishop \& H. Ostrum. Portsmouth, NH: Boynton/Cook, 1997. 19-26. 
---. "Systems of Genres and the Enactment of Social Intentions." Genre and the New Rhetoric. Eds. A. Freadman \& P. Medway. London: Taylor \& Francis, 1994. 79-101.

Bazerman, Charles \& Howard Tinberg. "Writing Is an Expression of Embodied Cognition.” In Linda Adler-Kassner \& Elizabeth Warble, pp. 74-75.

Berlin, Isaiah. Four Essays on Liberty. London: Oxford UP, 1969.

Berlinsky, Edward G. Kenneth Burke, Identification, and Psychoanalytic Theory. The Catholic University of America, ProQuest. UMI Dissertation Publishing, 1997. 9828834.

Bhabha, Homi K. Nation and Narration. London: Routledge, 1990. Print.

Bhatia, Vijay K. "Genre as Interdiscursive Performance in Public Sphere.” Genre and the Performance of Publics, editors Mary Jo Reiff \& Anis Bawarshi, Utah State UP, 2016, pp. $25-42$.

Bitzer, Lloyd. “The Rhetorical Situation.” Philosophy and Rhetoric, vol.1, 1968, pp. 1-14.

Bogost, Ian. Alien Phenomenology, or What It's Like to Be a Thing. University of Minnesota Press, 2007.

Boudinot, Elias. "Editorial.” The Cherokee Phoenix. June 17, 1829.

---. "Editorial." The Cherokee Phoenix. November 12, 1831.

Boulware, Tyler. Deconstructing the Cherokee Nation: Town, Religion, and Nation among Eighteenth-Century Cherokees. University of Florida, 2011. Print.

Bowen, Catherine Drinker. Miracle at Philadelphia: The Story of the Constitution Convention May to September 1787, Back Bay Books, 1987. Print.

Bryant, Levi. Onto-Cartography: An Ontology of Machines and Media. Edinburg University Press, 2014. 
Burke, Kenneth. A Grammar of Motives. University of California Press, 1969. Print.

---. A Rhetoric of Motives. University of California Press, 1969. Print.

Butalia, Urvashi. The Other Side of Silence: Voices from the Partition of India. Durham: Duke UP, 2000.

Campbell, K.K., and K. H. Jamieson. Form and Genre: Shaping Rhetorical Action. Falls Church: Speech Communication Association, 1978. Print.

Carlyle, Thomas. The French Revolution: A History. Vol. 1, London, J.M. Dent \& Sons, LTD., 1906. Print.

Cass, Lewis. "Removal of the Indians: January 1830." The Cherokee Removal: A Brief History with Documents, edited by Theda Purdue and Michael D. Green, Bedford/St. Martin's, 2005, pp.115-121.

Chakrabarty, Dipesh. Provincializing Europe: Postcolonial Thought and Historical Difference. Princeton UP, 2000.

Chauhan, R.S. The Political Development in Nepal, 1950-70: Conflict between Tradition and Modernity. New York: Barnes and Noble, 1972.

Cheney, George. "The Rhetoric of Identification and the Study of Organizational Culture." Quarterly Journal of Speech, Vol. 69, 1983, pp. 143-158.

Coenen, Dan T. The Story of The Federalists: How Hamilton and Madison Reconceived America. Published by Twelve Table Press, 2007. Print.

Conley, Robert J. Cherokee Thoughts, Honest and Uncensored. University of Oklahoma Press, 2008. Print. 
Crow, Todd. "Census Shows Increase in Cherokee Respondents.” Cherokee Phoenix. February 21, 2012.

Denson, Andrew. Demanding the Cherokee Nation. Indian Autonomy and American Culture 1830-1900. Lincoln and London: University of Nebraska Press, 2004. Print.

Derrida, Jacques. Of Grammatology, translated by Gayatri Chakravorty Spivak, John Hopkins University Press, 1976.

Devitt, Amy. Writing Genres. Southern Illinois UP, 2004. Print.

Dirlik, Arif. The Postcolonial Aura: Third World Criticism in the Age of Global Capitalism. Boulder: Westview Press, 1998. Print.

Elkins, Zachary, Tom Ginsburg and James Melton. The Endurance of National Constitutions. London: Cambridge UP, 2009. Print.

Emerson, Ralph Waldo. The Political Emerson: Essential Writings on Politics and Social Reform. Edited by David M. Robinson, Beacon Press, 2004.

Estrem, Heidi. "Disciplinary and Professional Identities are Constructed through Writing.” In Linda Adler-Kassner \& Elizabeth Warble, pp. 55-56.

Ferguson, Robert A. The American Enlightenment 1750-1820. Harvard UP, 1997, Print.

Fleischmann, Glen. The Cherokee Removal, 1838: Am Entire Indian Nation was Forced Out of Its Homeland. Franklin Watts, Inc., 1971.

Foucault, Michel. "What is an author?", The Norton Anthology of Theory and Criticism. General editor Vincent B. Leitch, W.W. Norton and Company, 2001, pp. 1622-1636.

Fukuyama, Francis. The End of History and The Last Man. Free Press, 1992. Print. 
Gammelgaard, Karen. "Constitution as a Transnational Genre: Norway 1814 and the Habsburg Empire 1848-1849.” In Gammelgaard \& Holmoyvik. 92-107.

Gammelgaard, Karen \& Eirik Holmoyvik. eds. Writing Democracy: The Norwegian Constitution 1814-2014. New York: Berghahn Books, 2015.

Geertz, Clifford. The Interpretation of Cultures, Basic Books, 1973, Print.

Gellner, David. “From Group Rights to Individual Rights and Back: Nepalese Struggle Over Culture and Equality." Culture and Rights: Anthropological Perspectives. Eds. Jane K. Cowan, et al. New York: Cambridge UP, 2001. 177-200.

Gilhooley, Simon J. "The Framers Themselves: Constitutional Authorship during Ratification." American Political Thought 2.1 (Spring 2013): 62-88.

Goldstein, Alyosha. "Colonialism, Constituent Power, and Popular Sovereignty." J19: The Journal of Nineteenth-Century Americanists, vol. 2. no. 1, Spring 2014, pp. 148-153.

Graff, Richard \& Wendy Winn. “Kenneth Burke’s 'Identification’ and Chaim Perelman and Lucie Olbrechts-Tyteca's ‘Communion': A Case of Convergent Evolution?” Promise of Reason: Studies in the New Rhetoric. eds. John T. Gage. Southern Ilinois University Press, 2003. Print.

Guha, Ranajit. Dominance without Hegemony: History and Power in Colonial India. Cambridge: Harvard UP, 1998.

Gustafson, Sandra M. Eloquence Is Power: Oratory \& Performance in Early America. Published by University of North Carolina Press, 2000. Print. 
Hachhethu, Krishna. "Democracy and Nationalism: Interface between State and Ethnicity in Nepal.” Contributions to Nepalese Studies 30.2 (July 2003): 217-252.

Hagen, Susan I. The Rise of Ethnic Politics in Nepal: Democracy in the Margin. New York: Routledge, 2010.

Harmen, Graham. Tool-Being: Heidegger and the Metaphysics of Things. Open Court, 2002.

Hamilton, Alexander. “Alexander Hamilton's Conjectures About the New Constitution 1787.” In The Debate on the Constitution: Federalist and Anti-federalist Speeches, Articles, and Letters During the Struggle over Ratification. Part One. Published by The Library of America, 1984. Print.

Harris, Joseph. "The Idea of Community in the Study of Writing." College Composition and Communication, vol. 40, Feb. 1989, pp. 11-22.

Harvey, David. The Condition of Postmodernity: An Inquiry into the Origin of Cultural Change. Wiley, 1992.

Hayles, N. Katherine. How We Think: Digital Media and Contemporary Technogenesis. University of Chicago Press, 2012.

Hershberger, Mary. "Mobilizing Women, Anticipating Abolition: The Struggle against Indian Removal in the 1830s." The Journal of American History, vol. 86, no. 1, Jun 1999, pp. $15-40$.

Hobsbawm, Eric. Nations and Nationalism since 1780. Cambridge: Cambridge UP, 1992. 
Hoxie, Fredrick E. 'Sovereignty's Challenge to Native American (and United States)

History.” J19: The Journal of Nineteenth-Century Americanists, vol. 2, no. 1, Spring 2014, pp. 137-142.

Hutt, Michael. "Drafting the Nepal Constitution 1990.” Asian Survey 31.11 (Nov. 1991): 10201039.

Jackson, Andrew. "To the Cherokee Tribe of Indians East of the Mississippi River." Mason Weekly Telegraph IX:42. April 9, 1835.

Jefferson, Thomas. “To James Madison.” 6 Sept. 1789. The Republic of Letters: The Correspondence between Thomas Jefferson and James Madison 1776-1826. Vol. I. editor James Morton Smith, W.W.W. Norton, 1995.

Joint Council of the Cherokee Nation and the Eastern Band of Cherokee Indians. Resolution \#00-08. A Resolutions Opposing Fabricated Cherokee "Tribes” and "Indians."

Jordon, Jay. 'Dell Hymes, Kenneth Burke’s ‘identification,' and the Birth of Sociolinguistics.” Rhetoric Review vol. 24, no. 3, 2005, pp. 264-279.

Joshi, Bhuwan 1. and Leo E. Rose. Democratic Innovations in Nepal: A Case Study of Political Acculturation. Berkeley and Los Angles: University of California Press, 1966.

Justice, Daniel Heath. Our Fire Survives the Storm. The Cherokee Literary History. The University of Minnesota Press, 2006.

Kent, Thomas. "On the Very Idea of Discourse Community." College Composition and Communication, vol. 24, no. 4, Dec. 1991, pp. 425-445. 
Kirk, John W. "Kenneth Burke and Identification.” Quarterly Journal of Speech, vol. 47, no. 4, 1961, pp. 414-415.

Konkle, Maureen. Writing Indian Nations: Native Intellectuals and the Politics of Historiography, 1827-1863. The University of North Carolina Press, 2004.

Krupat, Arnold. Ethnocriticism. University of California Press, 1992. Print.

Lacan, Jacques. "The Mirror-Stage as Formative of the I as Revealed in Psychoanalytic Experience. Ecrits: A Selection. W.W. Norton and Co., 2004, pp. 3-9.

Lantzer, Jason S. "Washington as Cincinnatus: A Model of Leadership.” In George Washington: Foundation of Presidential Leadership and Character. Edited by Ethan Fishman, William D. Pederson, and Mark J. Rozell, published by Praeger, 2001. Print. pp. 33-54.

Latour, Bruno. We Have Never Been Modern. Harvard University Press, 1993.

Law, David S. “The Myth of the Imposed Constitution.” Social and Political Foundations of Constitutions. Editors Denis J. Galligan and Mila Versteeg; Cambridge UP, 2013, pp. 239-68.

Lawoti, Mahendra. “Contentious Politics in Democratizing Nepal.” Lawati-2007. 17-47

---. "Democracy, Dominion and Exclusionary Constitutional-Engineering Process in Nepal, 1990.” Lawoti-2007. 48-70.

---. Towards a Democratic Nepal: Inclusive Political Institutions for a Multicultural Society. New Delhi: Sage Publications, 2005. Print.

Leeds, Stacy L. "Whose Sovereignty? Tribal Citizenship, Federal Indian Law, and Globalization.” Arizona State Law Journal, vol. 46, no.1, Spring 2014, pp. 89-105. 
Lemond, Eric D. "Overcoming the Politics of Reform: The Story of the Cherokee Nation of Oklahoma Constitutional Convention." American Indian Constitutional Reform and the Rebuilding of Native Nations. edited by Eric D. Lemond, University of Texas Press, 2006. pp. 287-222.

Levy, Pierre. Becoming Virtual: Reality in the Digital Age. Translated by Robert Bononno, Plenum Trade, 1998.

Lincoln, Abraham. "The Gettysburg Address." 19 Nov. 1863. The Collected Works of Abraham Lincoln. Editor Roy P. Basler, Rutgers UP, 1955, Print.

Longaker, Mark. Rhetoric and the Republic: Politics, Civic Discourse, and Education in Early America. Tuscaloosa: University of Alabama Press, 2007. Print.

Looby, Christopher. Voicing America: Language, Literary Form, and the Origin of the United States. published by The University of Chicago Press, 1996. Print.

Lunsford, Andrea A. "Writing Is Informed by Prior Experience.” In Linda Adler-Kassner \& Elizabeth Warble, pp. 54-55.

Perdue, Theda. "Traditionalism in the Cherokee Nation: Resistance to the Constitution of 1827." The Georgia Historical Quarterly, vol. 66, no. 2, 1882, pp. 159-170.

---. Nations Remembered: An Oral History of the Five Civilized Tribes, 1865-1907. Westport: Greenwood Press, 1980. Print.

Peters, Richard. "Reports or Cases Argued and adjudged in the Supreme Court of the States, in January Term, 1831. Reports of the Cases Argued and Decided in the Supreme Court of the United States: 1-351 US; 1790-October term, 1955, Book 8. Edited by Stephen Keys 
Williams, Edwin Burritt Smith, Earnest Hitchcock, Lawyers Co-operative Publishing Company, 1883, Digitized September 21, 2006, pp. 20-48.

Longaker, Mark Garrett. Rhetoric and the Republic: Politics, Civic Discourse, and Education in Early America. The University of Alabama Press, 2007.

Lyons, Scott Richard. "Rhetorical Sovereignty: What Do American Indians Want from Writing?" College Composition and Communication, vol. 51, no. 3, Feb. 2000, pp. 447468.

Malagodi, Mara. Constitutional Nationalism and Legal Exclusion: Equality, Identity Politics and Democracy in Nepal (1990-2007). Delhi: Oxford UP, 2013.

---. “Constitution Drafting as Cold War Realpilitk: Sir Ivor Jennings and Nepal’s 1959 Constitution." Constitution-making in Asia: Decolonisation and State-building in the aftermath of the British Empire. ed. H. Kumarsingham. London \& New York: Routledge, 2016.

Malcolm, Joyce Lee. "Introduction” in The Struggle for Sovereignty: Seventeenth-Century English Political Tracts. Volume I. Indianapolis: Liberty Fund, 1999.

Malecki, Edward J., and Bruno Moriset. The Digital Economy: Business Organizations, Production Processes, and Regional Developments. Routledge, 2008.

Mao, LuMing. Reading Chinese Fortune Cookie: The Making of Chinese American Rhetoric. Utah State University Press, 2006.

---. "Persuasion, Cooperation, and Diversity of Rhetorics.” Rhetoric Society Quarterly, vol. 20, no. 2, spring, 1990), pp. 131-142.

Martin, Emily. "Towards an Anthropology of Immunology: The Body as Nation-state." Medical Anthropology Quarterly 4.4 (December 1990): 410-426. 
McLoughlin, William G. Cherokee Renascence in the New Republic. Princeton University Press, 1986.

Miles, Tiya. "Circular Reasoning: Recentering Cherokee Women in the Antiremoval Campaigns." American Quarterly, vol. 61, no. 2, June 2009, pp. 221-243.

Miller, Carolyn. “Genre as Social Action.” Quarterly Journal of Speech 70 (1984): 151-67. Print.

Miyoshi, Masao. "A Borderless World? From colonialism to transnationalism and the decline of the nation-state.” Critical Inquiry 19.4 (Summer 1993): pp. 726-51.

Morgan, Edmund S. Inventing the People: The Rise of Popular Sovereignty in England and America, Norton, 1988.

Morton, Timothy. The Ecological Thought. Harvard University Press, 2010.

Musolff, Andreas. Metaphor, Nation, and the Holocaust: The Concept of Body Politic. New York: Routledge, 2010.

Nepal-Britain Treaty of 1923

Pandey, Gyanendra. Remembering Partition: Violence, Nationalism and History in India. Cambridge: Cambridge UP, 2001.

Parajulee, Ramjee P. The Democratic Transition in Nepal. New York: Rowman \& Littlefield Publishers, INC., 2000. Print.

Paris, Jones and Malcolm Langford. "Between Demos and Ethnos: The Constitution and the Indigenous Rights.” International Journal of Minority Rights 18.3 (June 2011): 369-386. 
Parkinson, Charles O. H. "British Constitutional Thought and the Emergence of Bill of Rights in Britain's Oversees Territories in Asia and Decolonisation." Constitution-Making in Asia: Decolonisation and State-building in the aftermath of the British Empire. ed. H.

Kumarasingham. London: Routledge, 2016. 36-54.

Parlapiano, Alicia \& Adam Pearce. "Only $9 \%$ of America Chose Trump and Clinton as the Nominees." The New York Times. The New York Times. 1 Aug. 2016. Web. 1 Jan 2017.

PMO India, "PM Narendra Modi’s Speech at Nepal Constituent Assembly." Online Video clip. YouTube. YouTube, 3 August 2014. Web. 27 July 2016.

Pocock, J.A. P. The Machiavellian Moment: Florentine Political Thought and the Atlantic Republican Tradition. Published by Princeton University Press, 1975. Print.

Prior, Paul. "From Speech Genres to Mediated Multimodal Genre Systems: Bakhtin, Voloshinov, and the Question of Writing." Genre in the Changing World. 17-34.

Rana, Pashupati Shumshere J. B. "Book Review: The Political Development in Nepal, 1950-70: Conflict between Tradition and Modernity." The American Political Science Review. 69.1 (1975): 300-301. Print.

Reiff, Jo Mary \& Anis Bawarshi. "From Genre Turn to Public Turn." Genre and the Performance of Publics. Eds. Mary Jo. Reiff \& Anis Bawarshi. Logan: Utah State UP, 2016. 3-22.

Ridge, John. "Letter to Albert Gallatin: February 27, 1826." The Cherokee Removal: A Brief History with Documents, edited by Theda Purdue and Michael D. Green, Bedford/St. Martin's, 2005, pp. 35-44. 
Riker, William H. The Strategy of Rhetoric: Campaigning for the American Constitution. Yale UP, 1996, Print.

Russell, David. "Rethinking Genre in School and Society: An Activity Theory Analysis." Written Communication 14.5: (1997): 504-554.

Schmid, Ulrich. "Constitution and Narrative: Peculiarities and Genre in the foundational laws of USSR and Russian Federation.” Trans. Katherine Bower. Stud East Eur Thought 62 (2010): 431-451.

---. "The Norwegian Constitution and the Rhetoric of Political Poetry.” In Gammelgaard \& Holmoyvik. 77-91.

Schneider, Bethany. "Boudinot's Change: Boudinot, Emerson, and Ross on Cherokee Removal." ELH (Journal of English Literary History), vol. 75, 2008, pp. 151-177.

Schoenfeld, Benjamin N. "Nepal's Constitution: Model 1962.” The Indian Journal of Political Science 24.4 (October-December 1963): 326-336. Silko, Leslie Marmon. Ceremony. Penguin Books, 2006.

Sellers, M.N.S. American Republicanism: Roman Ideology in the United States Constitution. Published by Macmillan, 1994. Print.

Sen, Amartya. Poverty and Famines: An Essay on Entitlement and Deprivation. London: Oxford, 1981.

Shalhope, Robert E. "Towrads a Republican Synthesis: The Emergence of an Understanding of Republicanism in American Historiography." The William and Mary Quarterly, vol. 29, no. 1 (Jan 1972). pp. 49-80. Print. 
Singer, Joseph William. "The Indian States of America. Parallel Universes and Overlapping Sovereignty." American Indian Law Review, vol. 38, no.1, 2014), pp. 1-33.

Sparkes, Andy. “Two Hundred Years of Nepal-Britain Relations: A Way Forward.” Speech delivered in Kathmandu on 15 September 2013. Transcript available at:

https://www.gov.uk/government/speeches/two-hundred-years-of-nepal-britain-relations-a-way-

forward

Strauss, David A. The Living Constitution. New York: Oxford UP, 2010.

Sturm, Circe. Blood Politics: Race, Culture, and Identity in the Cherokee Nation of Oklahoma. University of California Press, 2002. Print.

Sugauli Treaty 1816

Sussman, Robert Wald. The Myth of Race: The Troubling Persistence of an Unscientific Idea. Harvard University Press, 2014.

Sutherland, Arthur. Constitutionalism in America: Origin and Evolution of its Fundamental Ideas. Published by Blaisdell Publishing Company, 1965. Print.

Swales, John M. "Words of Genre-Metaphors of Genre." Genre in a Changing World. eds. Charles Bazerman, Adair Bonini, \& Debora Figueiredo. Fort Collins, Colorado: The WAC Clearinghouse, 2009, Print, pp. 3-16.

Sweet, Timothy. American Georgics: Economy and Environment in Early American Literature. University of Pennsylvania Press, 2002.

Tinnell, John. "All the World's a Link: The Global Theatre of Mobile World Brouwers.” enculturaltion (published December 14, 201). Web. http://www.enculturation.net/all-the-worlds-a-link. Accessed June 20, 2017. 
Villanueva, Victor. "Writing Provides a Representation of Ideologies and Identities.” In Linda Adler-Kassner \& Elizabeth Warble, pp. 57-58.

Vimalassery, Manu. “Counter-Sovereignty.” J19: The Journal of Nineteenth-Century Americanists, vol. 2, no. 1, 2014, pp. 142-148.

Warner, Michael. The Letters of the Republic: Publication and Public Sphere in EighteenthCentury America. Harvard University Press, 1992.

Warner, William B., Erik Holmoyvik, \& Mona Ringvej. “The Thing That Invented Norway.” In Gammelgaard \& Holmoyvik, pp. 21-42.

Washington, George. "Letter, George Washington to Senate on Cherokee Indian.” Lib. Of Cong. Web. 10 September 2015.

Weiser, M. Elizabeth. Burke, War, Words: Rhetoricizing Dramatism. Columbia: U of South Carolina P, 2008.

West, Cornel. Race Matters. New York: Vintage Books, 1994.

Wible, Scott. "Professor Burke’s 'Bennington Project."” Rhetoric Society Quarterly, vol 38, no. 3 (Summer, 2008), pp. 259-282.

Wilkins, David E., and K. Tsiannina Lamawaima. Uneven Ground: American Indian Sovereignty and Federal Law. University of Oklahoma Press, 2002. Press.

Wood, Gordon S. The Radicalism of the American Revolution. Published by Alfred A. Knopf, 1992. Print.

Woodward, G.C. The Idea of Identification. State University of New York Press, 2003. 
Yancey, Kathleen Blake. "Coming to Terms: Composition/ Rhetoric, Threshold Concepts, and a Disciplinary Core.” In Linda Adler-Kassner \& Elizabeth Warble, pp. xvii-xxxi. 